\title{
1993 Baseline Solid Waste Management System Description
}

\author{
L. L. Armacost \\ R. A. Fowler \\ H. S. Konynenbelt
}

February 1994

Prepared for the U.S. Department of Energy under Contract DE-AC06-76RLO 1830

Pacific Northwest Laboratory Operated for the U.S. Department of Energy by Battelle Memorial Institute 


\title{
DISCLAIMER
}

This report was prepared as an account of work sponsored by an agency of the United States Government. Neither the United States Government nor any agency thereof, nor Battelle Memorial Institute, nor any of their employees, makes any warranty, expressed or implied, or assumes any legal liability or responsibility for the accuracy, completeness, or usefulness of any information, apparatus, product, or process disclosed, or represents that its use would not infringe privately owned rights. Reference herein to any specific commercial product, process, or service by trade name, trademark, manufacturer, or otherwise does not necessarily constitute or imply its endorsement, recommendation, or favoring by the United States Government or any agency thereof, or Battelle Memorial Institute. The views and opinions of authors expressed herein do not necessarily state or reflect those of the United States Government or any agency thereof.

\author{
PACIFIC NORTHWEST LABORATORY \\ operated by \\ BATTELLE MEMORIAL INSTITUTE \\ for the \\ UNITED STATES DEPARTMENT OF ENERGY \\ under Contract DE-AC06-76RLO 1830
}

Printed in the United States of America

Available to DOE and DOE contractors from the

Office of Scientific and Technical Information, P.O. Box 62, Oak Ridge, TN 37831; prices available from (615) 576-8401. FTS 626-8401.

Available to the public from the National Technical Information Service, U.S. Department of Commerce, 5285 Port Royal Rd., Springfield, VA 22161. 
PNL -8990

AD-940

Report Prepared for Westinghouse Hanford Company

1993 BASELINE SOLID WASTE MANAGEMENT

SYSTEM DESCRIPTION

L. L. Armacost

R. A. Fowler

H. S. Konynenbelt

February 1994

Prepared for

the U.S. Department of Energy

under Contract DE-AC06-76RLO 1830

Pacific Northwest Laboratory

Richland, Washington 99352 


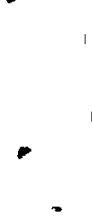




\section{EXECUTIVE SUMMARY}

Pacific Northwest Laboratory has prepared this report under the direction of Westinghouse Hanford Company. The report provides an integrated description of the system planned for managing Hanford's solid low-level waste, low-level mixed waste, transuranic waste, and transuranic mixed waste.

The primary purpose of this document is to illustrate a collective view of the key functions $\mathrm{planned}$ at the Hanford Site to handle existing waste inventories, as well as solid wastes that will be generated in the future. By viewing this system as a whole rather than as individual projects, key facility interactions and requirements are identified and a better understanding of the overall system may be gained.

The system is described so as to form a basis for modeling the system at various levels of detail. Model results provide insight into issues such as facility capacity requirements, alternative system operating strategies, and impacts of system changes (i.e., startup dates). This description of the planned Hanford solid waste processing system

- defines a baseline system configuration

- identifies the entering waste streams to be managed within the system

- identifies basic system functions and waste flows

- highlights system constraints.

This system description will evolve and be revised as issues are resolved, planning decisions are made, additional data are collected, and assumptions are tested and changed. Out of necessity, this document will also be revised and updated so that a documented system description, which reflects current system planning, is always available for use by engineers and managers. It does not provide any results generated from the many alternatives that will be modeled in the course of analyzing solid waste disposal options; such results will be provided in separate documents. 
$\bullet$ 


\section{ACRONYMS}

$\begin{array}{ll}\text { CTTF } & \text { Commercial Thermal Treatment Facility } \\ \text { D\&D } & \text { decontamination and decommissioning } \\ \text { DST } & \text { double-shell tank } \\ \text { EPA } & \text { U.S. Environmental Protection Agency } \\ \text { FDC } & \text { functional design criteria } \\ \text { HIC } & \text { High Integrity Container } \\ \text { LLMW } & \text { low-level mixed waste } \\ \text { LLW } & \text { low-level waste } \\ \text { MPSC } & \text { Multipurpose Storage Complex } \\ \text { NDE/NDA } & \text { nondestructive examination and nondestructive assay } \\ \text { PFP } & \text { Plutonium Finishing Plant } \\ \text { PNL } & \text { Pacific Northwest Laboratory } \\ \text { PUREX } & \text { Plutonium-Uranium Extraction } \\ \text { QA } & \text { quality assurance } \\ \text { RWM } & \text { restricted waste management } \\ \text { SDRD } & \text { Standard Design Requirements Document } \\ \text { SST } & \text { single-shell tank } \\ \text { SWB } & \text { standard waste box } \\ \text { SWITS } & \text { Solid Waste Information and Tracking System } \\ \text { SWOC } & \text { Solid Waste Operations Complex } \\ \text { TRU } & \text { transuranic waste and transuranic mixed waste } \\ \text { TRUSAF } & \text { Transuranic Storage and Assay Facility } \\ \text { TSD } & \text { Treatment, Storage, and Disposal } \\ \text { TTF } & \text { Thermal Treatment Facility } \\ \text { TWRS } & \text { Tank Waste Remediation System } \\ \text { WAC } & \text { waste acceptance criteria } \\ \text { WDOE } & \text { Washington Department of Ecology } \\ \text { WHC } & \text { Westinghouse Hanford Company } \\ \text { WIPP } & \text { Waste Isolation Pilot Plant } \\ \text { WRAP } & \text { Waste Receiving and Processing Facility } \\ & \end{array}$




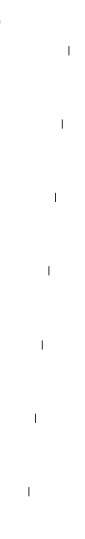




\section{WASTE CLASSIFICATION ACRONYMS}

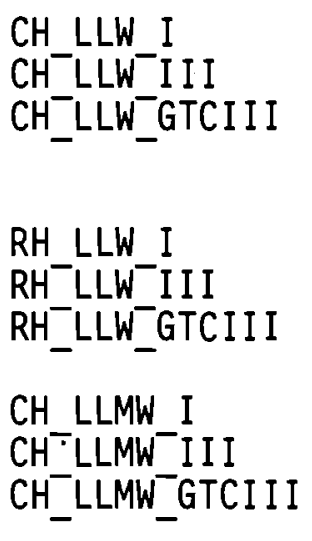

RH_LLMW_I
RH-LLMW-II I
RH_LLMW_GTCI I I
CH_TRU

RH_TRU

CH_TRU_SUSPECT

RH_TRU_SUSPECT
Contact-handled low-level waste, Class I

Contact-handled low-level waste, Class II I

Contact-handled low-level waste, greater than

Class III

Remote-handled low-level waste, Class I

Remote-handled low-level waste, Class III

Remote-handled low-level waste, greater than Class III

Contact-handled low-level mixed waste, Class I

Contact-handled low-level mixed waste, Class II I

Contact-handled low-level mixed waste, greater than

Class III

Remote-handled low-level mixed waste, Class I Remote-handled low-level mixed waste, Class II I

Remote-handled low-level mixed waste, greater than

Class II I

Contact-handled transuranic waste and

Contact-handled transuranic mixed waste

Remote-handled transuranic waste and

Remote-handled transuranic mixed waste

Contact-handled waste that has not been fully characterized and is suspected to have a transuranic component

Remote-handled waste that has not been fully

characterized and is suspected to have a transuranic component 
.

. 


\section{CONTENTS}

EXECUTIVE SUMMARY .................... .

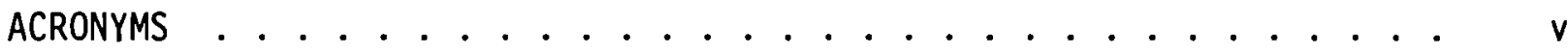
WASTE CLASSIFICATION ACRONYMS . . . . . . . . . . . . vii

1.0 INTRODUCTION . . . . . . . . . . . . . . . . 1.1

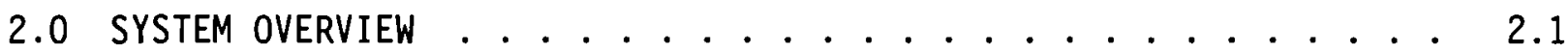

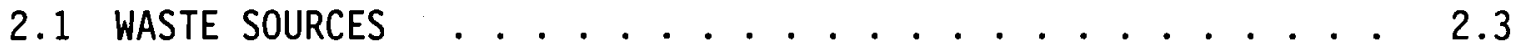

2.2 RECEIPT AND STORAGE . . . . . . . . . . . . 2.4

2.3 TREATMENT $\ldots \ldots \ldots \ldots \ldots$

2.4 DISPOSAL . . . . . . . . . . . . . . . . 2.10

2.5 ISSUES AND SPECIAL CASES . . . . . . . . . . 2.11

3.0 STORAGE FACILITIES . . . . . . . . . . . . . . . 3.1

3.1 EXISTING SMALL STORAGE BUILDINGS . . . . . . . . 3.1

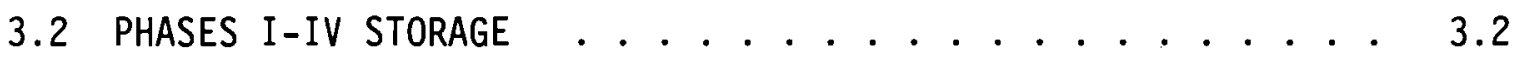

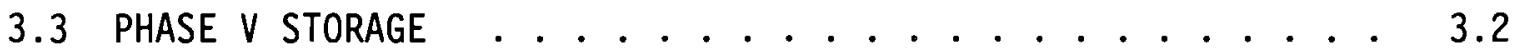

3.4 CAISSONS AND RETRIEVABLE STORAGE/TRENCHES . . . . . . . 3.5

3.5 STORAGE FOR LONG LENGTH TANK EQUIPMENT . . . . . . . . . 3.5

4.0 TREATMENT FACILITIES . . . . . . . . . . . . . . 4.1

4.1 WRAP MODULE $1 \ldots \ldots \ldots . \ldots . \ldots . \ldots . \ldots$

4.2 WRAP MODULE $2 A \ldots \ldots \ldots \ldots$

4.3 WRAP MODULE $2 B \ldots \ldots \ldots \ldots . \ldots . \ldots . \ldots . \ldots . \ldots$

4.4 THERMAL TREATMENT FACILITY . . . . . . . . . . . 4.8

4.5 T-PLANT . . . . . . . . . . . . . . . 4.8

5.0 DISPOSAL SITES $\ldots \ldots \ldots . \ldots \ldots . \ldots \ldots$

5.1 WASTE ISOLATION PILOT PLANT $\ldots \ldots \ldots . \ldots . \ldots . \ldots$ 
5.2 MIXED-WASTE DISPOSAL TRENCH $\ldots \ldots \ldots \ldots . \ldots \ldots$

5.3 EXISTING LOW-LEVEL WASTE BURIAL SITE . . . . . . . . 5.2

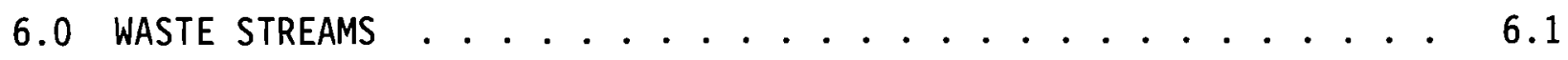

6.1 LOW-LEVEL WASTE STREAMS . . . . . . . . . 6.5

6.1 .1 Newly Generated CH_LLW_I in Drums . . . . . . 6.5

6.1 .2 Newly Generated CH_LLW_I in Boxes . . . . . . 6.7

6.1.3 Newly Generated and Retrieved CH_LLW_III in Drums . 6.9

6.1.4 Newly Generated and Retrieved CH_LLW_III in Boxes and DST/SST Equipment ........ 6.13

6.1.5 New7y Generated Shielded RH_LLW_I and RH_LLW_III in Drums and Boxes . ........ 6.15

6.2 LOW-LEVEL MIXED-WASTE STREAMS . . . . . . . . . 6.17

6.2.1 New1y Generated and Retrieved CH_LLMW in Drums and Caissons ........... 6.17

6.2.2 Newly Generated CH_LLMW in Boxes and DST/SST Equipment . . . . . . . . . 6.21

6.2.3 Newly Generated Shielded RH_LLMW in Drums and Caissons .............. 6.23

6.2.4 Newly Generated Shielded RH_LLMW in Boxes and DST/SST Equipment ........... 6.25

6.3 TRANSURANIC WASTE STREAMS . . . . . . . . . . 6.29

6.3 .1 Retrieved CH_TRU_SUSPECT in Drums ....... 6.29

6.3 .2 Retrieved CH_TRU_SUSPECT in Boxes ....... 6.33

6.3.3 Newly Generated CH_TRU in Drums and DST/SST

Equipment ............... 6.35

6.3.4 Newly Generated $\mathrm{CH}_{-}$TRU in Boxes ......... 6.37

6.3.5 Newly Generated Shielded RH_TRU and

Retrieved RH TRU SUSPECT in Drums and in

Casks from Càissōns ........... 6. 6.39

6.3.6 Newly Generated Shielded RH_TRU, DST/SST

Equipment, and Retrieved $\mathrm{RH}^{-}$TRU_SUSPECT

in Boxes 
7.0 REFERENCES $\ldots \ldots \ldots \ldots \ldots \ldots . \ldots \ldots . \ldots \ldots$ APPENDIX A - CALCULATIONS FOR BOX OVERPACK VOLUMES . . . . . . . A.1 APPENDIX B - CALCULATIONS FOR OPEN-SORT-PACKAGING PROCESSING IN WRAP MODULE $1 \ldots \ldots \ldots$. . . . . . . . . . .

APPENDIX C - PLANNING ASSUMPTIONS FOR SWOC FACILITY OPERATIONAL

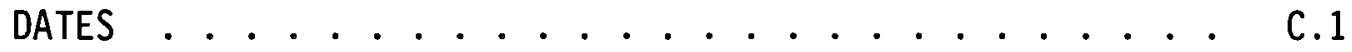




\section{FIGURES}

2.1 Hanford Solid Waste Management System Concept . . . . . . . 2.2

3.1 Phase V Storage Facility and Functions . . . . . . . 3.3

4.1 WRAP Module $1 \ldots \ldots . \ldots . \ldots . . \ldots . . \ldots 4$

4.2 WRAP Module $2 A \ldots \ldots . \ldots . \ldots . \ldots . \ldots . \ldots$

4.3 WRAP Module $2 B \ldots \ldots \ldots . \ldots . \ldots . \ldots . \ldots . \ldots$

4.4 Thermal Treatment Facility Waste Processing . . . . . . . 4.9

4.5 T-Plant Facility Waste Processing . . . . . . . . . 4.11

6.1 Legend for Waste Stream Diagrams . . . . . . . . 6.3

6.2 Newly Generated CH_LLW_I in Drums . . . . . . . . . 6.4

6.3 Newly Generated CH_LLW_I in Boxes ............ 6.6

6.4 Newly Generated and Retrieved CH_LLW_III in Drums . . . . . 6.8

6.5 Newly Generated and Retrieved CH_LLW_III in Boxes . . . . . . . . . . 6.12
and DST/SST Equipment . . . . . .

6.6 Newly Generated Shielded RH_LLW_I and RH_LLW_III in . . . . . . . 6. 6.14
Drums and Boxes . . . . . . . . . .

6.7 Newly Generated and Retrieved CH_LLMW in Drums
and Caissons . . . . . . . . . . . . . . . 6. . . . . . . . .

6.8 Newly Generated CH_LLMW in Boxes and DST/SST Equipment . . . . . 6.20

6.9 Newly Generated Shielded RH_LLMW in Drums and Caissons . . . . . 6.22

6.10 Newly Generated Shielded RH_LLMW in Boxes and DST/SST Equipment . . . . . . . . . . . . 6.24

6.11 Retrieved CH_TRU_SUSPECT in Drums . . . . . . . . 6.28

6.12 Retrieved CH_TRU_SUSPECT in Boxes .......... 6.32

6.13 New1y Generated CH_TRU in Drums and DST/SST Equipment . . . . . 6.34

6.14 Newly Generated $\mathrm{CH}_{-} \mathrm{TRU}$ in Boxes ... . . . . . . . 6.36

6.15 Newly Generated Shielded RH_TRU TRUM and Retrieved
RH_TRU_SUSPECT in Drums and in Casks from Caissons . . . . . 6.38 
6.16 Newly Generated Shielded RH_TRU, DST/SST Equipment, and Retrieved RH_TRU_SUSPECT in Boxes . . . . . . . . . . . . 6.42

A.1 Overpack BM-14/S . . . . . . . . . . . . . . . . . . . A.2

A.2 Overpack BM-36/S . . . . . . . . . . . . . . . . . . A.3

A.3 Overpack BM-68/S . . . . . . . . . . . . . . . . . . . A.4

A.4 Overpack/Box Versus Cube Box . . . . . . . . . . . . . A.5

A.5 Overpack/Box Versus Box . . . . . . . . . . . . . . . . A.6 


\section{$\underline{\text { TABLES }}$}

2.1 Storage Facilities and Capabilities ........... 2.5

2.2 Treatment Facilities and Capabilities . . . . . . . 2.8

2.3 Disposal Facilities and Capabilities .......... 2.10

4.1 Capacity Limits Used for the Baseline System Description and Model Results ................. 4.3

6.1 Waste Categories and Their Corresponding Waste Streams . . . 6.2 


\subsection{INTRODUCTION}

This document, prepared by Pacific Northwest Laboratory (PNL) ${ }^{(a)}$ under the direction of Westinghouse Hanford Company (WHC), provides an integrated description of the system planned for managing Hanford's solid low-level waste (LLW), low-level mixed waste (LLMW), and transuranic/transuranic mixed waste (designated as TRU). It identifies the waste streams entering the system, defines the primary functions planned for management of these wastes, describes the major facilities and principal technologies planned to perform these functions, and shows the flow of waste through the system from receipt to disposal.

This system description provides a collective view of the key treatment, storage, and disposal facilities planned at the Hanford Site. By viewing this system as a whole rather than as individual projects, key facility interactions and requirements may be identified and studied, and a better understanding of the overall system gained. Further, models will be generated based upon the system described here to allow planners to address issues such as facility capacity requirements, waste flows between facilities, the volume of waste ultimately requiring offsite disposal, or the impacts of changes to the system.

This document is intended to be used in combination with other documents that provide detail on the amount and characteristics of waste streams resulting from retrieval (Anderson 1990), wastes held in storage buildings while awaiting treatment (Duncan 1989), and the wastes expected from future operations (Valero et al. 1993). Such a collection of documents provides an initial basis from which long-term technological, programmatic, and funding needs can be defined and clearly documented prior to full-scale design.

In order to establish part of such a planning basis, this document addresses the following objectives:

(a) Pacific Northwest Laboratory is operated for the U.S. Department of Energy (DOE) by Battelle Memorial Institute under Contract DE-AC06-76RLO 1830 . 
- Document the system configuration. It describes the primary functions to be performed by the system, the facilities planned to provide the capacity for these functions, and the principal technologies currently planned for each facility. In addition, the report provides a clear reference "trail" to all documentation used in compiling the system description.

- Document assumptions followed in system planning. It identifies the assumptions that have been made at various levels in order to make progress in planning the system and defines the logic used in cases when insufficient detail or contradictory information has forced planners to follow a particular course of action.

- Provide a basis for modeling efforts. Baseline system parameters defined in this document will be modeled to generate a set of baseline system results. These results, which will be documented in a follow-up report, will use the system assumptions defined in this document to identify waste volume throughputs, storage requirements, and disposal needs. As more is learned about the system, alternatives to the baseline results will be identified, studied, and documented.

A preliminary system description was compiled, based upon existing project documents such as functional design criteria (FDC) reports, engineering studies, and other facility descriptions. Then, several consensus meetings were held with managers and engineers responsible for planning the storage facilities, treatment facilities, and disposal sites. These meetings allowed the responsible parties to review and revise the system description, ensuring that it reflected the most current thinking. In some cases, considerable uncertainty was expressed about exactly what should be modeled due to insufficient evaluation of alternatives. In those cases, it was necessary to make assumptions in order to complete the baseline description; these assumptions are noted throughout the text.

The system description will evolve and be revised as issues are resolved, planning decisions are made, additional data are collected, and assumptions are tested and changed. Out of necessity, this document will also be revised and updated so that a documented system description which reflects current system planning is always available for use by engineers and managers.

Because the document must serve several audiences, the system is described in various levels of detail and from different perspectives. 
Chapter 2.0 provides a broad overview of the entire system, from receipt to disposal, while Chapters 3.0 through 5.0 describe the planned facilities in more detail:

- Chapter 3.0 describes the planned storage facilities required to support treatment and disposal operations.

- Chapter 4.0 examines the treatment facilities planned to manage the waste.

- Chapter 5.0 addresses disposal plans.

The flow of each waste stream as it passes through the various solid waste handling facilities and operations is illustrated in diagrams contained in Chapter 6.0, which also contains assumptions regarding facility interactions, flow paths, and technologies.

No actual model results are contained in this document. However, the system described in this document can be studied using different modeling tools. For example, a preliminary model of this system description was developed using proprietary software (owned by Battelle). This model was termed "Scenario 6.5." Some slight revisions have been made to the system description since the release of the Scenario 6.5 results. New results reflecting these revisions will be completed using the SIMSCRIPT simulation tool and will be termed "Scenario 7.1." Alternatives will follow with "Scenario 7.1.xx" or, if significant revisions are made, "Scenario 7.2.xx."

When studying the results from these models, it would be beneficial to refer to this document for further explanation of routings and assumptions. Special studies can be performed with these tools by changing various components of the system. With all model results, any variations from this baseline description will be documented. 
$-$ 


\subsection{SYSTEM OVERVIEW}

For any present or future mission to succeed at Hanford, a system must exist which can receive solid wastes generated during ongoing operations, store these wastes until treatment capability is available, and treat them for final disposal. This chapter contains an overview of the Hanford system, depicted in Figure 2.1, which provides the necessary capability to receive, store, treat, and dispose of solid wastes. Each section of this chapter corresponds to one of the four major functional segments shown in Figure 2.1.

During its 30-year operating life, the solid waste management system is planned to receive waste from onsite operating facilities, offsite operating facilities, and environmental restoration/remediation activities. In addition, the system must provide treatment, storage, and disposal for wastes al ready held in inventory within the Hanford system. These wastes are stored in trenches, storage buildings, and storage caissons.

Waste arriving from operating facilities are planned to be distributed among several buildings for storage:

- Transuranic Storage and Assay Facility (TRUSAF) - currently storing TRU waste

- 2401 and 2402 - 13 small buildings currently storing LLMW

- Phases I-IV - 4 larger buildings currently storing LLMW (and a limited amount of low activity TRU)

- Phase $V$ - a planned storage facility with multi-purpose capabilities, including storage and work-in-process storage in support of treatment facilities, head gas testing, and general shipping/ receiving operations.

After waste materials are generated and sent to storage, many waste streams receive treatment in several planned facilities. The five major treatment facilities are shown in Figure 2.1. Waste Receiving and Processing (WRAP) Module 1 is planned to certify and package the retrieved and newly generated drums of TRU destined for the Waste Isolation Pilot Plant (WIPP). WRAP Module $2 \mathrm{~A}$ is $\mathrm{planned}$ to treat LLMW destined for onsite disposal, while 


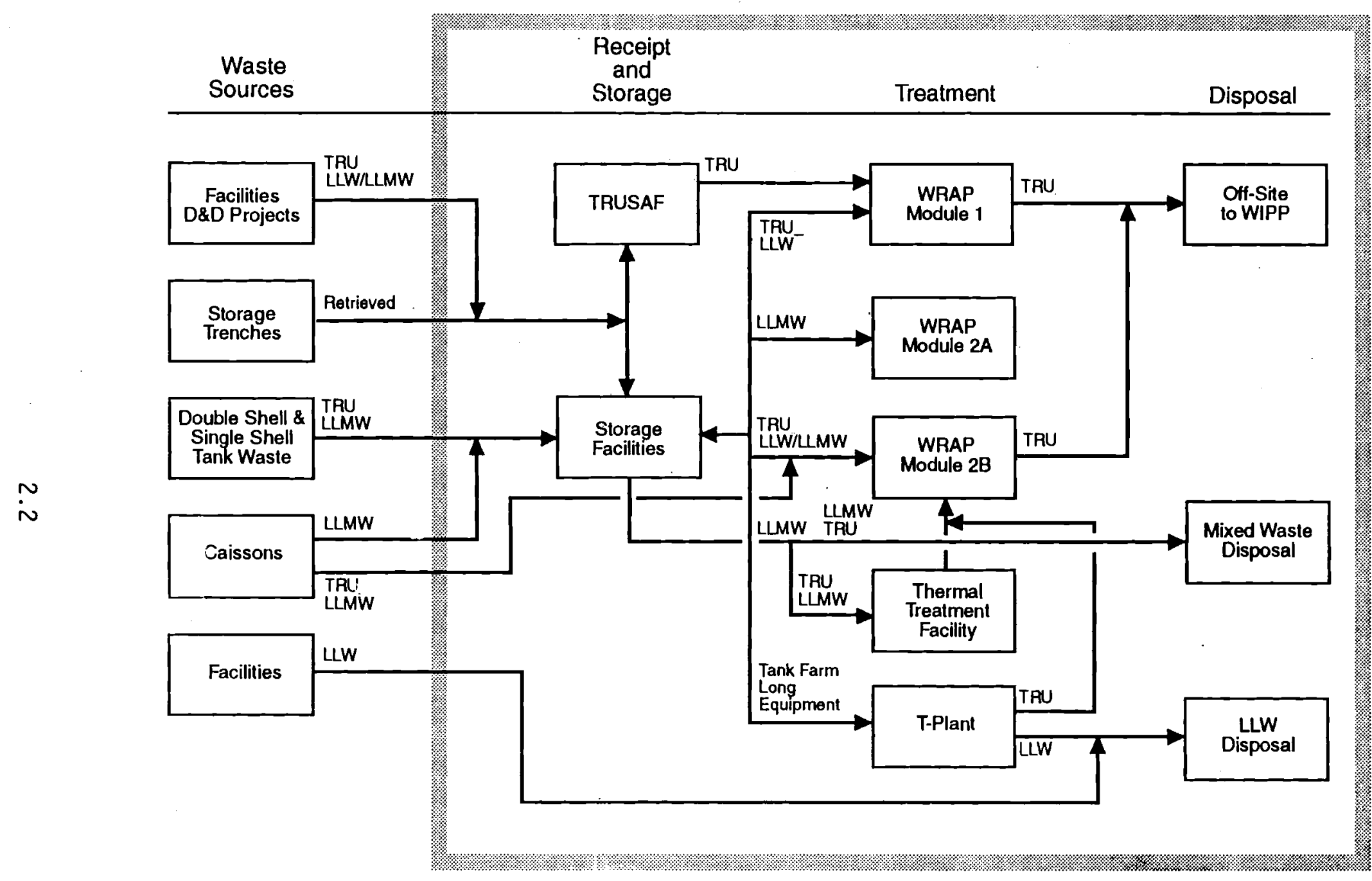

FIGURE 2.1. Hanford Solid Waste Management System Concept

S9J11046.7 
WRAP Module 2B is planned to treat both contact-handled $(\mathrm{CH})$ and remotehandled (RH) LLMW and TRU wastes. The Thermal Treatment Facility (TTF) will accept mixed waste that requires thermal destruction prior to burial. After thermal treatment, the LLMW and TRU waste will be sent to WRAP Module 2B for final packaging, certification, and shipment to disposal. The T-Plant facility is planned for size-reduction and processing of the long equipment retrieved from the single- and double-shell tanks. This waste will be routed to WRAP $2 B$ for final packaging and certification.

After treatment, waste will be sent to one of three disposal operations. The WIPP site in New Mexico will receive all TRU waste from Hanford. The other disposal facilities will provide permanent burial of LLW and LLMW on the Hanford Site. The GTCIII waste is routed to long-term storage.

\subsection{WASTE SOURCES}

The incoming waste streams shown in Figure 2.1 are solid materials, containerized liquids, or semisolid materials generated in the course of DOE operations at the Hanford Site. In addition, approval has been granted for some other sites within the DOE complex to ship their solid waste to Hanford. (At this time, no commercial wastes have been approved for shipment to Hanford.) Primary waste sources include

- processing facilities - These include existing facilities, such as the Plutonium-Uranium Extraction Plant (PUREX) the Plutonium Finishing Plant (PFP), or future facilities such as the Hanford Waste Vitrification Plant.

- environmental restoration activities - These operations include remediation of release sites, facility decommissioning and decontamination ( $D \& D$ ) projects, and recovery of equipment stored in tunnels. (Only a limited amount of this waste is currently identified as coming to solid waste operations.)

- stored waste retrieval - Considerable inventories of radioactive and mixed waste have been accumulating in trenches, caissons, and buildings at Hanford since 1970 . These wastes will be retrieved for appropriate treatment as facilities become available.

The amount of future waste is estimated each year by the generators and varies over time. The waste generators categorize waste using Hanford's waste 
classification scheme (WHC-EP-0063 [DOE 1991]), which is based on the radionuclide concentration and activity of the waste, as well as the dose rate at the surface of the waste container.

Two additional labels are used in this document to reflect waste characteristics that require special classification: CH_TRU_SUSPECT and RH_TRU_SUSPECT. These wastes are currently stored in trenches and buildings and are called suspect because not all waste characteristics are known, but the historical data suggest that the waste could contain TRU contaminants. Because regulations have changed since this material was placed in storage or because assay techniques have improved since that time, it is expected that only a portion of the waste originally identified as "suspect" TRU will actually be TRU. During treatment, such wastes will be subdivided into TRU, LLMW, and LLW components.

A11 waste stream labels are defined in the waste classification acronym list and more information about forecast waste volumes is provided in the annual forecast documents, the latest being the 1993 Solid Waste Reference Forecast Summary (Valero et al. 1993). The forecast summary document quantifies what waste streams are included in the forecast and identifies other waste streams that are not included in the forecast but could potentially impact the system. For example, waste generated from $D \& D$ of facilities that have not yet been identified as surplus are not included in the forecast. The document also addresses other uncertainties associated with the data.

\subsection{RECEIPT AND STORAGE}

The Hanford storage facilities provide the ability to receive waste and control inventories until a batch suitable for processing has accumulated, until treatment or disposal capacity is available, or until transportation to WIPP is available. Further, storage is provided for wastes that have received some treatment and require further processing, as well as for wastes that have been treated and are awaiting shipment to disposal. Table 2.1 shows the primary storage facilities, years of activity, waste categories stored, and other information. Of the storage facilities planned at Hanford, the TRUSAF and the 
IABLE 2.1. Storage Facilities and Capabilities

\begin{tabular}{|c|c|c|c|c|}
\hline Storage Type & Years of Activity & $\begin{array}{c}\text { Primary Waste } \\
\text { Categories }^{(n)}\end{array}$ & Other Comments & References \\
\hline TRUSAF & $\begin{array}{l}\text { Storage began in } \\
1985 \text { and will be } \\
\text { provided until all } \\
\text { TRU waste has been } \\
\text { certified and sent } \\
\text { to disposal. }\end{array}$ & TRU & $\begin{array}{l}\text { Examines and assays waste to } \\
\text { establish whether it is TRU } \\
\text { and may be certified for } \\
\text { shipment to WIPP. }\end{array}$ & Carlson 1993 \\
\hline $\begin{array}{l}\text { Existing Small } \\
\text { Storage Buildings } \\
(2401 \& 2402)\end{array}$ & $\begin{array}{l}\text { Storage began in } \\
1986 \text { and will be } \\
\text { available during all } \\
\text { operational years of } \\
\text { the SWOC. }\end{array}$ & $\begin{array}{l}\text { LLMW } \\
\text { LLW } \\
\text { TRU }\end{array}$ & \multirow{2}{*}{$\begin{array}{l}\text { Transfers waste to Phase } V \\
\text { Storage prior to any form of } \\
\text { treatment. }\end{array}$} & \multirow[b]{2}{*}{ Bafus 1988} \\
\hline $\begin{array}{l}\text { Phases I-IV } \\
\text { Storage Buildings }\end{array}$ & $\begin{array}{l}\text { Storage began in } \\
1991 \text { for Phase I and } \\
1993 \text { for Phases II- } \\
\text { IV and will be } \\
\text { available during all } \\
\text { operational years of } \\
\text { the SWOC. }\end{array}$ & $\begin{array}{l}\text { LLMW } \\
\text { LLW } \\
\text { TRU }\end{array}$ & & \\
\hline $\begin{array}{l}\text { Phase V Storage } \\
\text { Building }\end{array}$ & $\begin{array}{l}\text { Storage is expected } \\
\text { to begin in } 1999 \text { and } \\
\text { will be available } \\
\text { during all opera- } \\
\text { tional years of the } \\
\text { SWOC. }\end{array}$ & $\begin{array}{l}\text { LLW } \\
\text { LLMW } \\
\text { TRU }\end{array}$ & $\begin{array}{l}\text { - Transfers waste to and } \\
\text { from treatment } \\
\text { facilities. } \\
\text { - Provides work-in-process } \\
\text { storage for treatment } \\
\text { facilities. } \\
\text { - Performs head gas testing } \\
\text { for WIPP certification. } \\
\text { - Sends waste to burial. }\end{array}$ & Plowman 1991 \\
\hline Caissons & $\begin{array}{l}\text { Retrieval from the } \\
\text { caissons will begin } \\
\text { in the year } 2011 \text {, } \\
\text { one year after WRAP } \\
\text { Module } 2 \mathrm{~B} \text { begins } \\
\text { treating RH waste. }\end{array}$ & $\begin{array}{l}\text { LLMW } \\
\text { TRU }\end{array}$ & \multirow{2}{*}{$\begin{array}{l}\text { Transfers waste to Phase } V \\
\text { Storage prior to any form of } \\
\text { treatment. }\end{array}$} & \multirow[t]{2}{*}{ Carlson 1993} \\
\hline $\begin{array}{l}\text { Retrievable } \\
\text { Storage } \\
\text { (Trenches) }\end{array}$ & $\begin{array}{l}\text { Retrieval will begin } \\
\text { when Phase V Storage } \\
\text { begins in } 1999 \text { and } \\
\text { will last through } \\
2014 \text {. }\end{array}$ & TRU_SUSPECT & & \\
\hline $\begin{array}{l}\text { Long Equipment } \\
\text { Storage }\end{array}$ & $\begin{array}{l}\text { Storage capacity is } \\
\text { assumed to be } \\
\text { available from } 1994 \\
\text { through } 2023 .\end{array}$ & $\begin{array}{l}\text { LLMW } \\
\text { TRU }\end{array}$ & $\begin{array}{l}\text { A special storage area is } \\
\text { assumed to exist for the } \\
\text { single-shell and double- } \\
\text { shell tank long equipment. }\end{array}$ & $\begin{array}{l}\text { System } \\
\text { as sumption }\end{array}$ \\
\hline
\end{tabular}


Phase I-IV storage buildings have been accumulating inventories to date; Phase $V$ is scheduled to begin storing waste in 1999.

The TRUSAF is currently receiving TRU waste from generators. Waste received by the TRUSAF is examined and assayed to establish whether it is TRU and may be certifiable for shipment to WIPP. Certifiable TRU waste is stored in TRUSAF until processing facilities (WRAP Module 1) open in 1998, at which time this waste will be sent directly to treatment for final packaging, certification, and shipment to WIPP. TRUSAF will continue to provide storage during all years of the SWOC.

Currently, an inventory of mixed waste is being stored at the Central Waste Complex in the 2401 and 2402 Buildings (part of "Storage Facilities" in Figure 2.1). There are 13 buildings in all, which will provide storage for mixed waste until batching capability is available in Phase V. The 2401 and 2402 complexes have accumulated LLMW since 1986, and storage will be provided during all operational years of the SWOC.

Other storage buildings (Phases I-IV [Project W-016]) will store LLW and LLMW. Phase I came on-line in 1991, while Phases II-IV became operational in 1993 (Bafus 1988). In addition, waste is being stored in the caissons and retrievable trenches. These two storage areas have been identified in the "waste source" category in Figure 2.1 since a significant effort will be required to actually retrieve this waste for processing.

A planned multi-purpose storage facility, Phase $V$, will serve as a batching and lag storage facility supporting the treatment facilities. Phase $V$ will interface with all functional components of the system. All waste stored in Phases I-IV, 2401, and 2402 will be transferred to Phase V (Project $W$-112) prior to any form of treatment. Phase $V$ will also receive waste from retrieval operations and from waste generators and provide workin-process storage for the treatment facilities. In addition to storing waste, Phase $V$ will act as a transhipment station, transferring waste to and from treatment facilities and sending waste to the burial grounds. Phase $V$ will also perform head gas testing for certification of waste packages going to WIPP. 
A11 storage facilities will receive and store waste in contact-handled containers only. Any remote-handled sources destined for storage will be shielded to a contact-handled level during retrieval activities or at the waste generating facility prior to shipment.

\subsection{TREATMENT}

Several treatment facilities are planned at Hanford to create waste forms suitable for final disposal. The major elements of the treatment functions shown in Figure 2.1 include the various modules of the WRAP complex, which are still being designed and are expected to become operational at different times. The primary features of each treatment facility are identified in Table 2.2.

The first major treatment facility planned to be operational ( $\mathrm{planned}$ for early 1997 for LLW and 1998 for TRU waste) is WRAP Module 1, which will provide characterization and treatment for a limited set of waste types. WRAP Module 1 will receive $\mathrm{CH}_{-}$TRU waste in drums and standard waste boxes (SWBs) from TRUSAF and the Phase $V$ storage facility. The primary objective of WRAP Module 1 will be packaging and certification of these wastes for shipment to the WIPP (Hoover 1991); however, it will also serve as a characterization and certification facility for $\mathrm{CH}_{-} \mathrm{LLW}$.

A large portion of the waste received in WRAP Module 1 is expected to be retrieved waste for which the actual waste classification is unknown. This waste (labeled CH_TRU_SUSPECT) has been previously classified as TRU, but it is expected to contain a substantial portion of material that will actually be classified as LLW or LLMW after waste is characterized, sorted, and assayed within WRAP Module 1. A11 non-TRU wastes requiring further treatment will be sent to other processing facilities, while certified TRU wastes will be sent to Phase $V$ to await head gas testing. After head gas testing, the TRU drums and SWBs will return to WRAP Module 1 to be placed in TRUPACT-II containers for shipment to WIPP.

In addition to newly generated and retrieved $\mathrm{CH}_{\text {TRU }}$ waste, WRAP Module 1 will also provide sampling verification for approximately $10 \%$ of the total 
IABLE 2.2. Treatment Facilities and Capabilities

\begin{tabular}{|c|c|c|c|c|c|c|c|}
\hline Facility & $\begin{array}{l}\text { Start } \\
\text { Date }\end{array}$ & Primary Waste & $\begin{array}{c}\text { Principal Technologies } \\
\text { Deployed }\end{array}$ & $\begin{array}{l}\text { Waste Volume } \\
\text { Change }\end{array}$ & $\begin{array}{c}\text { Final } \\
\text { Certification }\end{array}$ & Other Comments & References \\
\hline T-PLANT & 1996 & $\begin{array}{l}\text { : RH TRU SUSPECT } \\
\text { : RH_LLMW }\end{array}$ & $\begin{array}{l}\text { - Size-reduction } \\
\text { - Characterization } \\
\text { - Shred-Grout for LLMW } \\
\text { - Packaging }\end{array}$ & Increase $(2: 1)$ & $\begin{array}{l}\text { No (sent to } \\
\text { WRAP Module 2B) }\end{array}$ & $\begin{array}{l}\text { - TRU waste } \\
\text { sent to WRAP } \\
\text { Module 2B for } \\
\text { processing and } \\
\text { certification } \\
\end{array}$ & $\begin{array}{l}\text { System } \\
\text { Assumption. } \\
\text { See Appendix C. }\end{array}$ \\
\hline $\begin{array}{l}\text { WRAP } \\
\text { MODULE } 1\end{array}$ & $\begin{array}{l}1997 \\
1998\end{array}$ & $\begin{array}{l}\cdot{ }^{C H} \angle L W \\
C_{-}^{-} T R U\end{array}$ & $\begin{array}{l}\text { - Characterization } \\
\text { - Sorting and } \\
\text { repackaging }\end{array}$ & $\begin{array}{l}\text { Reduction }(2: 1) \\
\text { Variable }\end{array}$ & $\begin{array}{l}\text { Yes } \\
\text { Yes }\end{array}$ & $\begin{array}{l}\text { - WIPP certi- } \\
\text { fication and } \\
\text { shipping } \\
\text { - Orums <1000 lb } \\
\text { - Boxes }<7000 \text { lb } \\
\end{array}$ & Hoover 1991 \\
\hline $\begin{array}{l}\text { WRAP } \\
\text { MODULE } 2 A\end{array}$ & 2000 & CH_LLMW & $\begin{array}{l}\text { - Debris treatment } \\
\text { - Encapsulation } \\
\text { - Particulate treatment } \\
\text { - Special treatment }\end{array}$ & $\begin{array}{l}\text { Increase }(2: 1) \\
\text { Increase }(2: 1) \\
\text { Increase }(2: 1) \\
\text { No volume change }\end{array}$ & $\begin{array}{l}\text { No (sent to } \\
\text { WRAP Module 1) }\end{array}$ & $\begin{array}{l}\text { - Treatment and } \\
\text { certification } \\
\text { for LLMW, } \\
\text { excluding } \\
\text { waste requir- } \\
\text { ing thermal } \\
\text { treatment } \\
\end{array}$ & Westcott 1991 \\
\hline $\begin{array}{l}\text { WRAP } \\
\text { MODULE 2B }\end{array}$ & $\begin{array}{l}2009 \\
2010 \\
2011\end{array}$ & $\begin{array}{l}\text { - CH waste in oversize } \\
\text { or overweight con- } \\
\text { tainers or TRU not } \\
\text { suitable for WRAP } \\
\text { Module } 1 \\
\text { - RH waste } \\
\text { - RH Caissons }\end{array}$ & $\begin{array}{l}\text { - Shred-Grout for LLMW } \\
\text { - Sort ing and packaging } \\
\text { for TRU }\end{array}$ & $\begin{array}{l}\text { Increase }(2: 1) \\
\text { Variable }\end{array}$ & Yes & $\begin{array}{l}\text { - Treatment and } \\
\text { certification } \\
\text { for oversized } \\
\text { containers and } \\
\text { remote-handled } \\
\text { waste } \\
\text { Contains a hot } \\
\text { cell for waste } \\
\text { up to } \\
2000 \mathrm{R} / \mathrm{hr} \\
\end{array}$ & Venetz 1993 \\
\hline TTF & $\begin{array}{l}2013 \\
2014 \\
2014 \\
2014\end{array}$ & $\begin{array}{l}: \text { CH_LLMW } \\
: \text { CH TRU } \\
: \text { RH-TRU } \\
: \text { RH_LLMW }\end{array}$ & - Plasma arc furnace & Reduction (5:1) & $\begin{array}{l}\text { No (sent to } \\
\text { WRAP Module 2B) }\end{array}$ & $\begin{array}{l}\text { After thermal } \\
\text { treatment, } \\
\text { waste shipped } \\
\text { to WRAP } \\
\text { Module 2B for } \\
\text { certification } \\
\text { and final } \\
\text { packaging }\end{array}$ & $\begin{array}{l}\text { Gillins } 1991 \\
\text { Place } 1993\end{array}$ \\
\hline
\end{tabular}


volume of newly generated CH_LLW (in drums). It is assumed that the remaining $90 \%$ of this waste stream will be shipped directly to onsite disposal via Phase V.

WRAP Module 2A, which is expected to begin operation in 2000, will perform extensive treatment processes to prepare CH_LLMW_I and CH_LLMW_III for onsite disposal (Westcott 1991). WRAP Module 2A is being structured primarily as a shred-grout facility including the addition of two other secondary treatment processes:

- encapsulation of lead and

- amalgamation and encapsulation of mercury.

Any waste forms not treatable by these processes will be diverted to other facilities for final treatment. The treated CH_LLMW will be returned to storage to await disposal.

WRAP Module 2B is expected to begin treating $\mathrm{CH}$ waste in 2009, $\mathrm{RH}$ waste in 2010 and alpha caisson waste in 2011. WRAP Module 2B will provide assay and repackaging capability for $\mathrm{CH}_{\text {_TR_SUSPECT }}$ and $\mathrm{CH}$ _TRU waste in boxes, as wel.1 as drums containing wastes that are not acceptable for WP.AP Module 1 (e:g., classified waste, heavy drums). WRAP Module $2 \mathrm{~B}$ will also have the capability to receive RH_TRU and RH_LLMW that has been shielded to contacthandled levels for transport and provide treatment for the remote-handled source material (Venetz 1993). Following certification, all CH_TRU will be returned to Phase $V$ for head gas testing and then to WRAP Module 1 to be loaded into TRUPACT containers, all remote-handled waste will be shipped directly to the appropriate disposal sites, and CH_LLW/LLMW will be returned to storage to await further processing or disposal.

The TTF is currently planned to begin treating CH_LLMW in 2013 and CH_TRU, RH_TRU, and RH_LLMW in 2014. The TTF is expected to treat combustible CH_TRU materials that cannot be certified in WRAP Module 1, combustible RH_TRU materials that cannot be certified in WRAP Module $2 \mathrm{~B}$, and LLMW that requires thermal treatment to meet requirements for disposal. The output product of the thermal treatment $p 1$ ant will be routed to disposal after final certification requirements are completed in WRAP Module $2 B$. 
The T-Plant serves mainly as a decontamination facility for Hanford operations. Until the WRAP Module 2B facility comes on-line, it is assumed to have an expanded role of performing treatment for the long equipment that is removed from double- and single-shell tanks. The treatment planned will remove the LLMW contamination from the equipment to the degree required by the EPA's Debris Rule, allowing the cleaned equipment to be disposed of as LLW. It is expected that some elements of the equipment will not be decontaminated to the degree required by the Debris Rule and this fraction of the total volume will be repackaged and routed to storage for final treatment in WRAP Module 2B. Once WRAP Module $2 B$ comes on-line, this stream of long equipment will be treated in both WRAP Module $2 \mathrm{~B}$ and the T-Plant.

\subsection{DISPOSAL}

Disposal is the final component of the system shown in Figure 2.1, and is the final destination for all waste streams. Table 2.3 lists disposal facilities and capabilities. Currently, the only Hanford operation offering permanent disposal is the LLW burial ground, which is accepting LLW from onand offsite waste generators. Another burial trench is being planned at Hanford to dispose of LLMW, which is assumed to be available by 2000 (a date coinciding with WRAP Module $2 A$ operations). In addition, WIPP will provide the final disposal for TRU waste starting in 2002.

\section{TABLE 2.3. Disposal Facilities and Capabilities}

\begin{tabular}{|c|c|c|c|c|c|}
\hline Disposal & $\begin{array}{c}\text { Dates of } \\
\text { Waste } \\
\text { Acceptance }\end{array}$ & $\begin{array}{l}\text { Waste } \\
\text { Categories } \\
\text { Accepted }\end{array}$ & Capacity & $\begin{array}{c}\text { Onsite } \\
\text { or } \\
\text { Offsite }\end{array}$ & References \\
\hline LLW Burial Ground & Ongoing & LLW & Provided as needed & Onsite & Carlson 1993 \\
\hline $\begin{array}{l}\text { Mixed Waste } \\
\text { Disposal Trench }\end{array}$ & $2002-2022^{(d)}$ & LLMW & $277,500 \mathrm{ft}^{3}$ & Onsite & Carlson 1993 \\
\hline WIPP & $2002-2020^{(a)}$ & TRU & $\begin{array}{l}\text { It is assumed that WIPP } \\
\text { wi } 11 \text { accept } 9,000 \\
\text { drums/yr of Hanford's CH } \\
\text { waste and 1,575 drums/yr } \\
\text { of Hanford's RH waste. }\end{array}$ & Offsite & DOE 1989 \\
\hline
\end{tabular}




\subsection{ISSUES AND SPECIAL CASES}

In the course of defining the baseline system and the various waste streams entering this system, several issues and special cases were identified. In most cases, the issues have not yet been addressed in the planning process, so assumptions were made about how they might be handled in the system.

- GTCIII waste - Requirements have not been defined for treating and disposing of any LLW GTCIII or LLMW GTCIII wastes. The GTCIII waste are assumed to be stored in Phase $V$ until treatment requirements are known and alternative solutions are assessed.

- long tank farm equipment - The equipment recovered from the tank farms in the process of cleaning the single-shell and doubleshell tanks is assumed to be processed at the T-Plant. Once WRAP Module 2B comes on-line, both the T-Plant and WRAP Module 2B will process this waste. After the T-Plant's closure, WRAP Module 2B will continue to process this waste through the remaining years of solid waste operations.

- waste with special physical characteristics - Several waste generators expect to send large pieces of equipment to the solid waste system. An example is the large, heavy, and highly contaminated equipment to be recovered from the PUREX tunnels. Similar waste would result from $D$ \& $D$ activity within any canyon facility at Hanford. Because facilities currently planned for the Hanford solid waste system would not be able to receive, store, or treat this waste, this stream is not addressed in this system description. It is assumed that this waste will not be treated until treatment capability exists.

- remote-handled waste - None of the storage facilities currently planned for the system have the capabilities required to receive, handle, and store waste containers that are remote-handled. All plans for the storage facilities assume that remote-handled sources will be placed in shielded containers at the generator or during the retrieval process.

- alpha caisson waste - This waste will be packaged into drums during retrieval and any remote-handled drums will be shipped directly to WRAP Module 2B in a shielded shipping cask. 


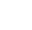




\subsection{STORAGE FACILITIES}

Storage is an essential function of the waste management process, supporting retrieval, treatment, and disposal (see Table 2.1 for information on storage facilities and capacities). Hanford solid waste storage facilities will provide:

- long-term storage for wastes that cannot be handled by the system because treatment technologies have not yet been specified, or because treatment and/or disposal capacity is not available - This waste will remain in long-term storage until facilities become operational to treat the waste or until disposal facilities become available. In this system description, long-term storage applies only to GTCIII wastes.

- incoming storage for waste prior to processing activities - This form of storage provides inventory control until suitable batches have accumulated for treatment and treatment capability exists.

- lag storage for waste that has already been handled by a treatment facility, but needs short duration, work-in-process storage prior to additional treatment activities - For example, waste that has been treated in WRAP Module 1 and needs further treatment in WRAP Module $2 \mathrm{~A}$ will be sent to lag storage prior to batching into WRAP Module 2A.

- outgoing storage for waste awaiting shipment to final disposal This form of storage provides inventory control until suitable batches have accumulated for shipment to disposal sites and final certification and documentation has been completed.

The storage facilities will batch and levelize waste flow to treatment facilities or accumulate waste packages until treatment facilities are operating. The current storage capacity is based upon building/loading plans which include aisle and working space. Tests should be performed using more conservative values.

\subsection{EXISTING SMALL STORAGE BUILDINGS}

Low-level waste and LLMW are being stored at the central waste complex in the 2401 and 2402 storage buildings. There are 13 buildings total, with each building capable of storing approximately 1000 drums. 
The TRUSAF also plays a role in the storage function. This facility will store TRU waste that will be sent directly to WRAP Module 1 for final certification and shipment to WIPP.

\subsection{PHASES I-IV STORAGE}

Large storage facilities constructed in Phases I through IV will provide interim storage for CH_LLW and CH_LLMW until Phase $V$ is completed in late 1993. Three of the buildings have $34,000 \mathrm{ft}^{2}$ of space, with the fourth having a larger area of $55,250 \mathrm{ft}^{2}$ (Bafus 1988). The three smaller facilities will provide a maximum capacity of 8,500 drums and the larger facility will hold 13,500 drums.

It should be noted that the FDC for these four buildings states that Phases I-IV will provide storage only for mixed waste generated through 1996. The baseline system assumes that this storage capability will be available as long as needed.

In addition, it is assumed that any CH_LLW_I and CH_LLW_III. waste that is generated prior to the start-up of the Phase $V$ facility will not require storage and will be sent directly to the burial grounds.

\subsection{PHASE V STORAGE}

The Phase $V$ storage facility, represented in Figure 3.1, provides the primary inventory control and waste batching station for the Hanford solid waste management system. This facility, planned to be operating by 1999, will receive all classes of waste, hold this material prior to treatment, provide a transhipment function between treatment facilities, and store treated waste awaiting disposal. The primary operations and segments of Phase $V$ are as follows:

- drum storage module - This module will provide incoming, lag, outgoing, and long-term storage for all waste received in 55-gallon drums and 85-gallon drum overpacks, with the exception of ignitable and potentially ignitable drums, which will be sent to a separate ignitable storage area. The drum storage module will be sized for approximately 21,300 drum equivalents, based on an estimated maximum incoming storage requirement from a 1 -year shutdown of WRAP Module 1 while WRAP Module 2A continues processing. 


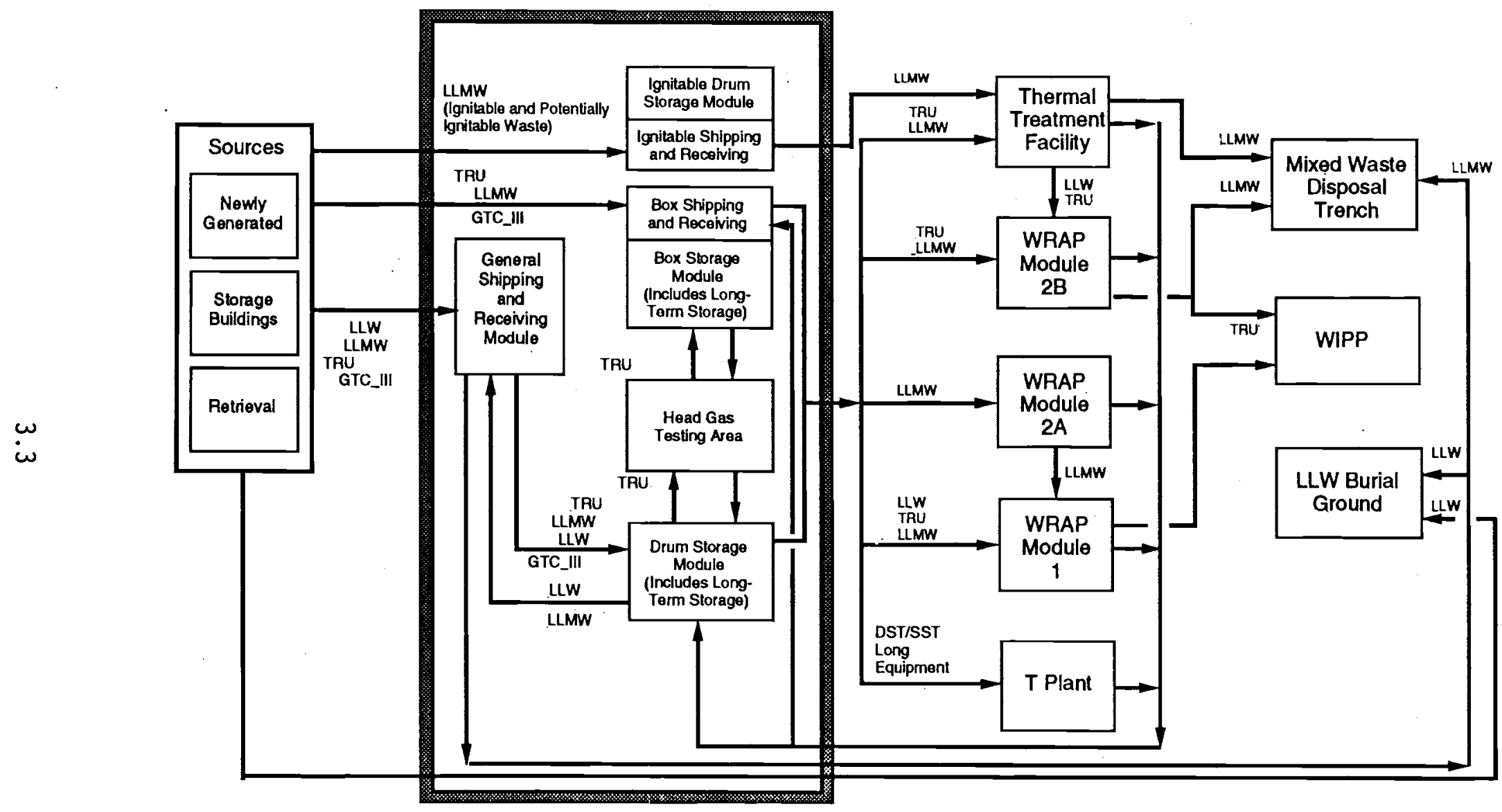

$\$ 9311046.1$

FIGURE 3.1. Phase V Storage Facility and Functions 
- ignitable drum storage module - This module will provide storage for ignitable and potentially ignitable mixed waste (waste containing combustible, flammable, or oxidizing constituents) in two segregated areas.

- box storage module - This module is designed to provide storage for SWBs and waste packages that are not manageable in the drum modules. The module is sized to contain approximately $42,000 \mathrm{ft}^{3}$ (5700 drum equivalents) of boxed waste.

- shipping and receiving modules - Three separate shipping and receiving modules will be used to handle the various waste types and container sizes. The Phase $V$ storage facility will have one general shipping and receiving area for all waste containers entering Phase $V$. A second shipping and receiving module will transfer all boxes to and from the box storage module. The third shipping and receiving module will transfer ignitable and potentially ignitable waste packages to and from the ignitable waste storage module.

- head gas testing area - The facility will also perform head gas testing, which must be performed on $\mathrm{CH}_{-}$TRU in drums and boxes prior to shipment to WIPP.

In order to determine actual storage requirements at Hanford, the baseline system will be modeled using an infinite capacity limit. By comparing these model results to the planned storage capacities, the analyst will be able to determine if the planned storage capacities are adequate.

It is important to note that any remote-handled waste requiring storage in Phase $V$ must be shielded to $200 \mathrm{mrem} / \mathrm{hr}$ or less prior to entering the facility. This shielded waste will be held in storage until appropriate treatment facilities become available.

Assumptions regarding Phase $V$ storage include the following:

- All waste sent to Phase $V$ storage will be in acceptable waste containers so that no further packaging will be required. Overpacking, when necessary, will be completed as part of the retrieval operation.

- $\mathrm{CH}$ drum overpacks will increase the waste stream volume by a factor of 1.55 , but since the storage is not sensitive to the actual size of the drum, the volume increase is not included in the baseline. RH drum overpacks will increase the waste stream volume by $3: 1$ and will be included. Box overpacks will increase the waste stream volume by a factor of 3.0. Box overpacks for the long equipment items from double-shell and single-shell tank (DST and SST) operations will have a 25:1 volume increase factor (if the waste volume 
is reported in terms of actuai waste) to address the very large overpacks and a 5.6:1 increase factor to address the extra floor space required in storage buildings.

- Phase $V$ will be the only facility shipping CH_LLW and CH_LLMW to onsite disposal facilities.

\subsection{CAISSONS AND RETRIEVABLE STORAGE/TRENCHES}

Retrieval from the caissons will begin in 2011, one year after WRAP Module 2B begins treating $\mathrm{RH}$ Waste. The waste expected from the caissons includes LLMW and TRU. Retrieval from the post-1970 trenches will begin in 1999 and will last through 2014. The waste will be packaged as TRU suspect waste until final assay in WRAP Module 1.

\subsection{STORAGE FOR LONG LENGTH TANK EQUIPMENT}

No storage facility has currently been designated to store the singleshell and double-shel1 tank long equipment prior to treatment in T-Plant and/or WRAP Module 2B. It is assumed that a special storage area will be available for this long equipment starting in 1994. 


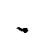

. 


\subsection{TREATMENT FACILITIES}

Treatment is a necessary function for most waste types prior to final disposal. Several Hanford facilities are planned to treat LLW, LLMW, and TRU wastes resulting from facility operations, retrieval of stored wastes and D\&D activities (see Table 2.2).

\subsection{WRAP MODULE 1}

The first major treatment facility planned for the Hanford solid waste management system is WRAP Module 1 of the WRAP complex, which will begin operation during the first quarter of 1997 for CH_LLW and in 1998 for TRU waste. Figure 4.1 illustrates the flows of waste through WRAP Module 1. This facility will provide the primary means of processing, packaging, and certifying a large fraction of Hanford's solid TRU waste prior to disposal at the WIPP.

The current capacity plans for this facility and that of other treatment facilities are provided in Table 4.1. The baseline system assumes that a11 facilities will begin operations at $30 \%$ capacity, increase to $70 \%$ for the second year, and operate at full capacity by the third year.

The primary missions of WRAP Module 1 are to certify LLW and to certify newly generated waste that has been assayed as TRU or retrieved wastes that are expected to have a TRU component. Only contact-handled waste arriving in 55-gallon drums, 85-gallon overpacks, and standard waste boxes or other waste boxes no 1 arger than $8 \times 5 \times 5 \mathrm{ft}$ will be accepted by WRAP Module 1 (Hoover 1991). Four major waste streams enter WRAP Module 1:

- Retrieved CH LLW and CH LLMW - Any retrieved drums identified as CH LLW during the iñitial trençh assay will be sent to the WRAP Module 1 opensort operation, compacted, and sent to Phase V storage; they will then be sent to the LLW burial ground from Phase V. For CH_LLMW, the waste wi11 be sent to the WRAP Module 1 open-sort operation, assayed, and then sent to Phase $V$ storage to await treatment in WRAP Module $2 A$. 


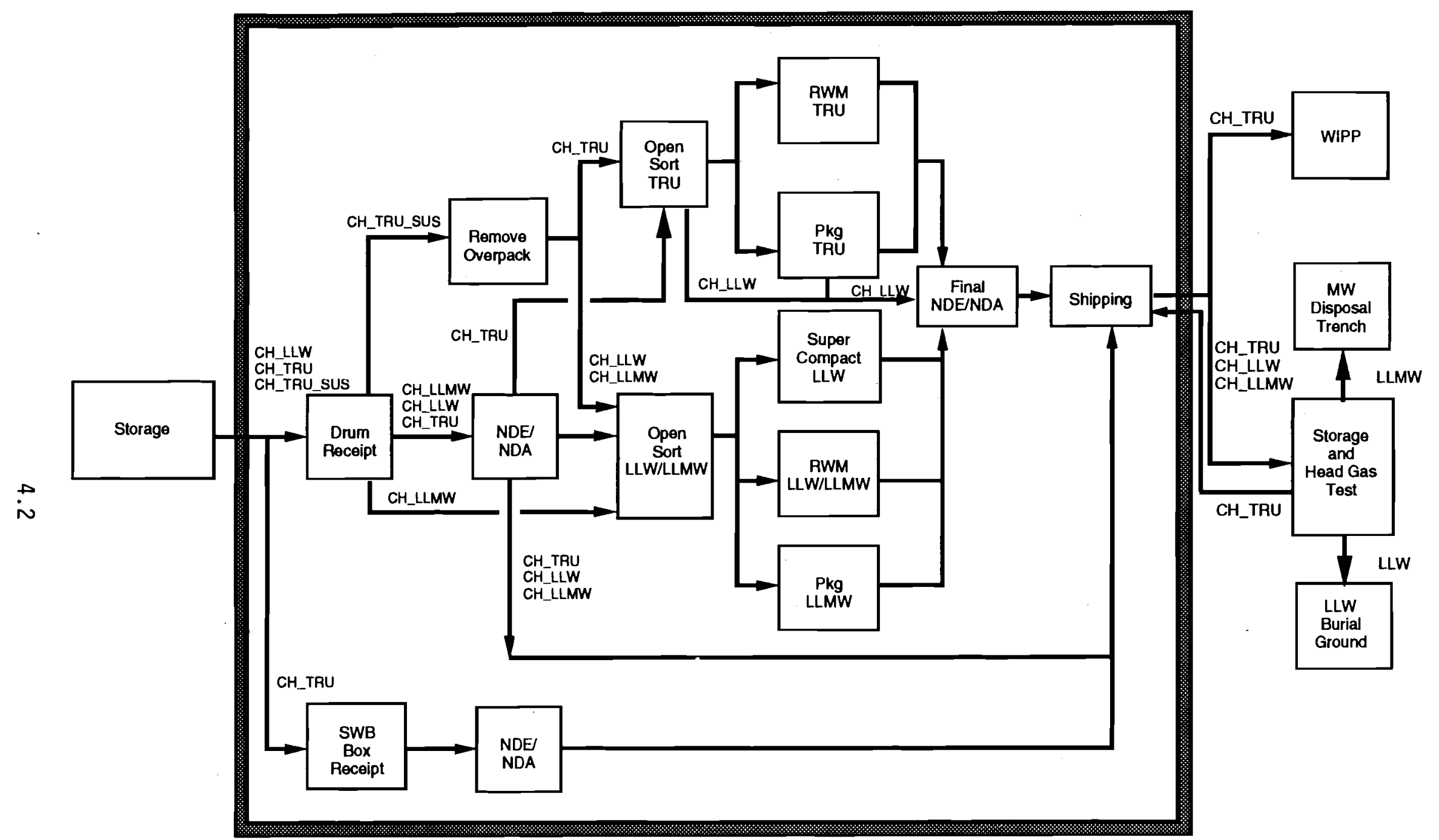

S9311046.4

FIGURE 4.1. WRAP Module 1 
IABLE 4.1. Capacity Limits Used for the Baseline System Description and Model Results

\begin{tabular}{|c|c|c|c|c|}
\hline \multirow[b]{2}{*}{ Facility } & \multirow[b]{2}{*}{ Start-up Dates } & \multirow[b]{2}{*}{ Uaste Streans } & \multicolumn{2}{|c|}{ Annual Capacity } \\
\hline & & & Containers & $\begin{array}{l}\text { Cubic } \\
\text { Meters }\end{array}$ \\
\hline T-Plant & 1996 & $\begin{array}{l}\text { RH_TRU } \\
\text { RH_LLMW }\end{array}$ & (a) & $\begin{array}{r}17 \\
327 \\
\end{array}$ \\
\hline WRAP Module 1 & $\begin{array}{l}\text { - } 1997 \text { for LLW } \\
\text { - } 1998 \text { for TRU }\end{array}$ & $\begin{array}{l}\text { CH_TRU } \\
\text { CH_TRU_SUSPECT } \\
\text { CH_LLW/LLMW }\end{array}$ & $\begin{array}{l}2100 \text { drums } \\
70 \text { SwBs } \\
2625 \text { drums } \\
2100 \text { drums }\end{array}$ & $\begin{array}{l}437 \\
119 \\
546 \\
437\end{array}$ \\
\hline WRAP Module $2 A$ & 2000 & CH_LLMW & $\begin{array}{l}3336 \text { drums } \\
4^{\prime} \times 4^{\prime} \times 8^{\prime} \text { boxes }\end{array}$ & $\begin{array}{l}695 \\
144\end{array}$ \\
\hline WRAP Module 2B & $\begin{array}{l}\text { - } 2009 \text { for } \mathrm{CH} \\
\text { - } 2010 \text { for RH } \\
\text { - } 2011 \text { for caissons con- } \\
\text { taining some SUSPECT } \\
\text { wastes }\end{array}$ & $\begin{array}{l}\text { CH_LLMW } \\
\text { CH_TRU } \\
\text { CH_TRU_SUSPECT } \\
\text { RH_LLW/LLMW } \\
\text { RH_TRU } \\
\text { RH_TRU_SUSPECT }\end{array}$ & $\begin{array}{l}601 \text { drums } \\
-- \text { boxes } \\
601 \text { drums } \\
-- \text { boxes }(b) \\
841 \text { drums } \\
-- \text { boxes }(b) \\
553 \text { drums } \\
-- \text { boxes } \\
770 \text { drums } \\
-- \text { boxes } \\
144 \text { drums } \\
-- \text { boxes }(b)\end{array}$ & $\begin{array}{r}125 \\
31 \\
125 \\
175 \\
2130 \\
2130 \\
115 \\
150 \\
160 \\
1400 \\
30 \\
50 \\
\end{array}$ \\
\hline TTF & $\begin{array}{l}-2013 \\
\text { - } 2014 \\
\text { - } 2014 \\
\text { - } 2014\end{array}$ & $\begin{array}{l}\text { CH_LLMW } \\
\text { CH_TRU } \\
\text { RH_LLMW } \\
\text { RH_TRU }\end{array}$ & $\begin{array}{r}2659 \text { drums } \\
10 \text { boxes } \\
29 \text { drums } \\
0 \text { boxes } \\
29 \text { drums } \\
2 \text { boxes } \\
0 \text { drums } \\
0 \text { boxes }\end{array}$ & $\begin{array}{r}553 \\
38 \\
6 \\
0 \\
6 \\
6 \\
0 \\
0\end{array}$ \\
\hline $\begin{array}{l}\text { (a) Waste st } \\
\text { (b) Number o }\end{array}$ & be of varied sizes. & & & \\
\hline
\end{tabular}

- Certifiable LLW/LLMW - WRAP Module 1 will also provide sampling verification for a quality assurance (QA) sample of newly generated waste shipped as CH_LLW and treated CH_LLMW. For LLW it, is assumed that the waste sample will be certified and shipped to onsite disposal via Phase $V$. The main waste lot from which the sample was taken is assumed not to enter the treatment system and will go directly to the LLW burial ground. For LLMW, the verification process becomes a lot acceptance test for treated LLMW. After the lot is accepted, the entire stream is sent to the LLMW burial ground from Phase $V$ storage or sent to long-term storage until the appropriate treatment is available.

- Certifiable TRU Waste - Certifiable TRU waste is received from storage buildings and undergoes initial nondestructive examination and nondestructive assay (NDE/NDA), which provides information on 
storage building for head gas testing, then returned to WRAP Module 1 to be placed in TRUPACT-II containers and shipped to the WIPP.

A small fraction of newly generated TRU waste is expected to contain items which prevent certification as meeting WIPP-WAC specifications. Aerosol cans, free liquids, particulates smaller than 10 microns, compressed gases, unopened containers larger than 1 gallon, lead brick, and lead shielding are all restricted items. Drums containing such items will be sent to an open-sort operation to remove the noncompliant items. Drums containing compressed gas cylinders will not be opened in WRAP Module 1 but will be routed to long-term storage until WRAP Module 2B comes on-line. After sorting, the certifiable component is packaged, assayed, and sent to storage to await shipment. Noncompliant items identified during sorting activities are sent to the restricted waste management (RWM) area, where they are treated and/or repackaged for processing in other facilities. All SWBs that cannot be certified are returned to Phase $V$ storage for treatment in WRAP Module 2B; WRAP Module 1 will not open boxes.

In addition, there are some TRU drums that, due to their contents, will not be routed to WRAP Module 1 . These include the drums with high loadings of ${ }^{238} \mathrm{Pu}$, overweight drums, drums with classified waste, and drums with internally shielded contents. The baseline system assumption is that $5 \%$ of the stream contains waste that will be classified as ignitable waste (with this going to the TTF) and another $5 \%$ will be routed to WRAP Module 2B (to address other wastes that WRAP Module 1 cannot address).

- Retrieved TRU - Retrieved drums will receive an initial assay at the trench. Based upon the assay data, the waste stream will be segregated into drums which may be classified as TRU waste and those drums that are clearly LLW or LLMW.

The TRU stream will be routed through the open-sort-packaging operations. A small fraction will be sent to the RWM area for further processing. The entire stream will then be sent to a final assay station prior to shipping to the WIPP.

\subsection{WRAP MODULE $2 A$}

The second major module of the WRAP complex is WRAP Module 2A, shown in Figure 4.2, which provides treatment required for $\mathrm{CH}_{-}$LLMW with hazardous constituents regulated by the Resource Conservation and Recovery Act through the 


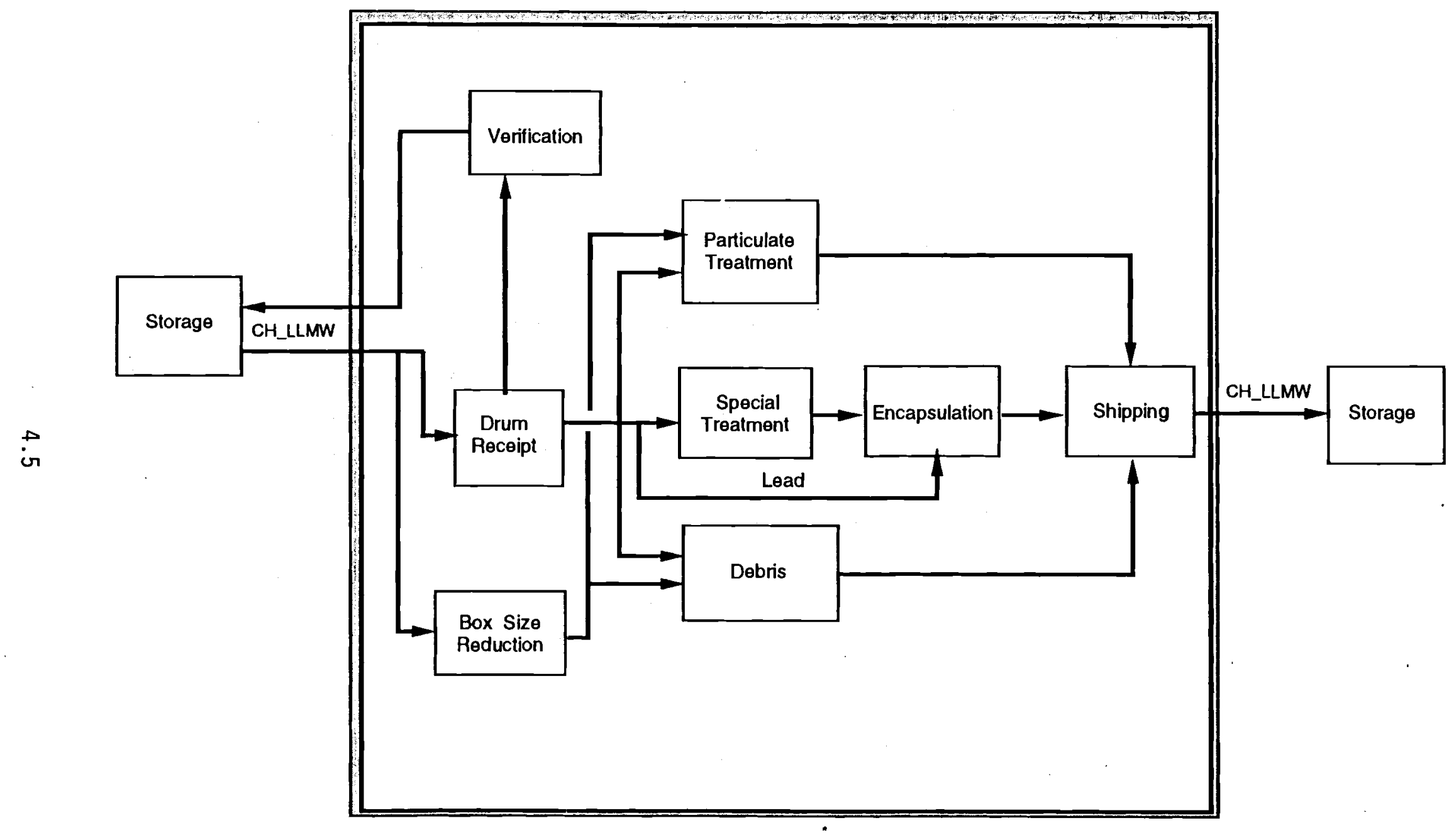

FIGURE 4.2. WRAP Module 2A 
U.S. Environmental Protection Agency (Westcott 1991). When the facility begins operation in 2000, it will process CH_LLMW_I and CH_LLMW_III from inventories accumulated since 1986, newly generated waste from facilities, secondary solids from Hanford liquid effluent treatment facilities, and LLMW generated or remaining from other solid-waste treatment facilities. Primary treatment activities in WRAP Module $2 \mathrm{~A}$ will be particulate/debris solidification or immobilization and lead encapsulation. Special treatment for small streams such as mercury will also be provided. Any mixed-waste constituents requiring thermal treatment will be routed to the TTF.

A fraction (20\%) of any incoming drums will be sent to WRAP Module $2 A$ to verify that the container contents match the manifest prior to sending the entire batch. These samples are repackaged in 55-gallon drums without treatment and are returned to storage while a full batch is accumulated for treatment. All waste exits WRAP Module $2 \mathrm{~A}$ in boxes for shipment to the onsite mixed-waste disposal trench.

\subsection{WRAP MODULE 2B}

WRAP Module $2 B$ is intended to provide capacity for several difficultto-treat waste streams, most notably remote-handled material and large boxes. WRAP Module 2B, shown in Figure 4.3 , will be structured to accept the following:

- retrieved CH TRU SUSPECT waste in oversized boxes and retrieved CH TRU SUSPECT wāste in drums not suitable for WRAP Module 1 (e.g., internālly shielded remote-handled waste, drums over 800 pounds, or classified waste)

- newly generated, internally shielded waste (RH_TRU and RH_LLMW)

- newly generated CH TRU in oversized boxes and in drums not suitable for WRAP Module 1 Te.g., aerosol cans, free liquids, or compressed gases)

- retrieved, remote-handled waste (greater than 200 mrem at the container surface) from trenches and caissons

- newly generated CH_LLMW packaged in large boxes. 


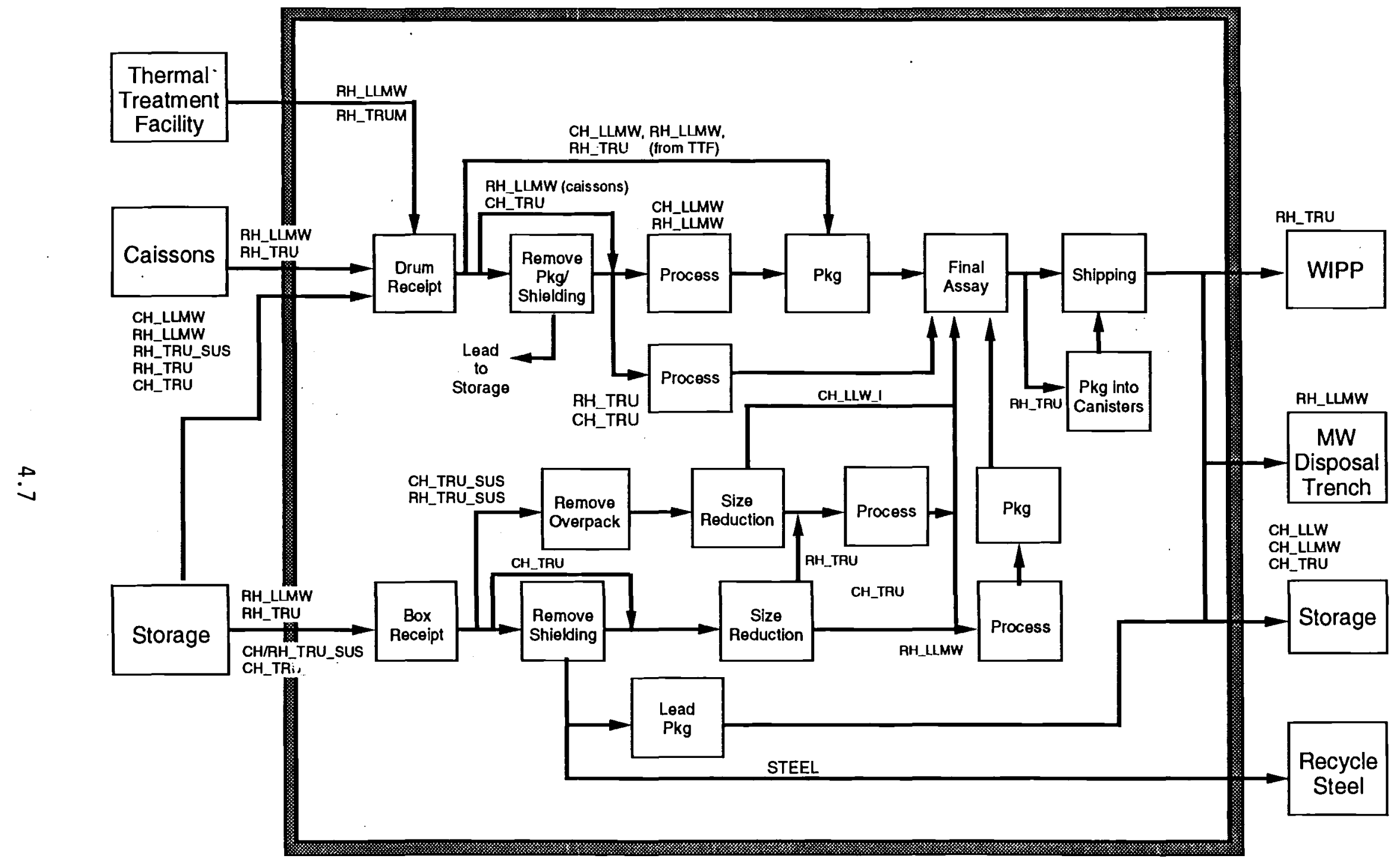

$\$ 9311046.3$

FIGURE 4.3. WRAP Module 2B 
Primary WRAP Module 2B activities include waste sorting, waste processing, waste repackaging, and final certification. Because many of the waste forms arriving in very large or very heavy containers cannot be processed easily, WRAP Module 2B will also have the capability to cut large objects into several smaller items. This operation, referred to as size-reduction, causes a waste volume increase due to final packaging into much smaller containers (e.g., drums).

\subsection{THERMAL TREATMENT FACILITY}

In addition to the various WRAP modules, a facility is planned to manage those waste streams requiring some form of thermal treatment prior to disposal. The TTF shown in Figure 4.4 will provide treatment and residue characterization for CH_LLMW, RH_LLMW, CH_TRU, and RH_TRU. ${ }^{\text {(a) }}$

With the current planning to maximize the treatment of waste within WRAP Module $2 \mathrm{~A}$ (thereby accelerating the disposal of this waste), the volume of waste that will be thermally treated has diminished to the point that a single plasma arc furnace can address all expected waste. The output of this type of furnace will be a glass slag. The TTF will package the slag in accordance with the ultimate disposal location (at WIPP for any TRU waste and onsite for the remainder).

\subsection{T-PLANT}

The T-Plant serves mainly as a decontamination facility for Hanford operations and will have an expanded role of performing treatment for the long equipment that is removed from double- and single-she11 tanks. The treatment planned will remove the mixed waste contamination from the equipment to the degree required by the EPA's Debris Rule, allowing the cleaned equipment to be disposed of as LLW.

(a) Place, B. G. Internal memo dated March 1992, "Design Basis for Hanford's RMW Thermal Treatment Facility Engineering Study." Westinghouse Hanford Company, Richland, Washington. 


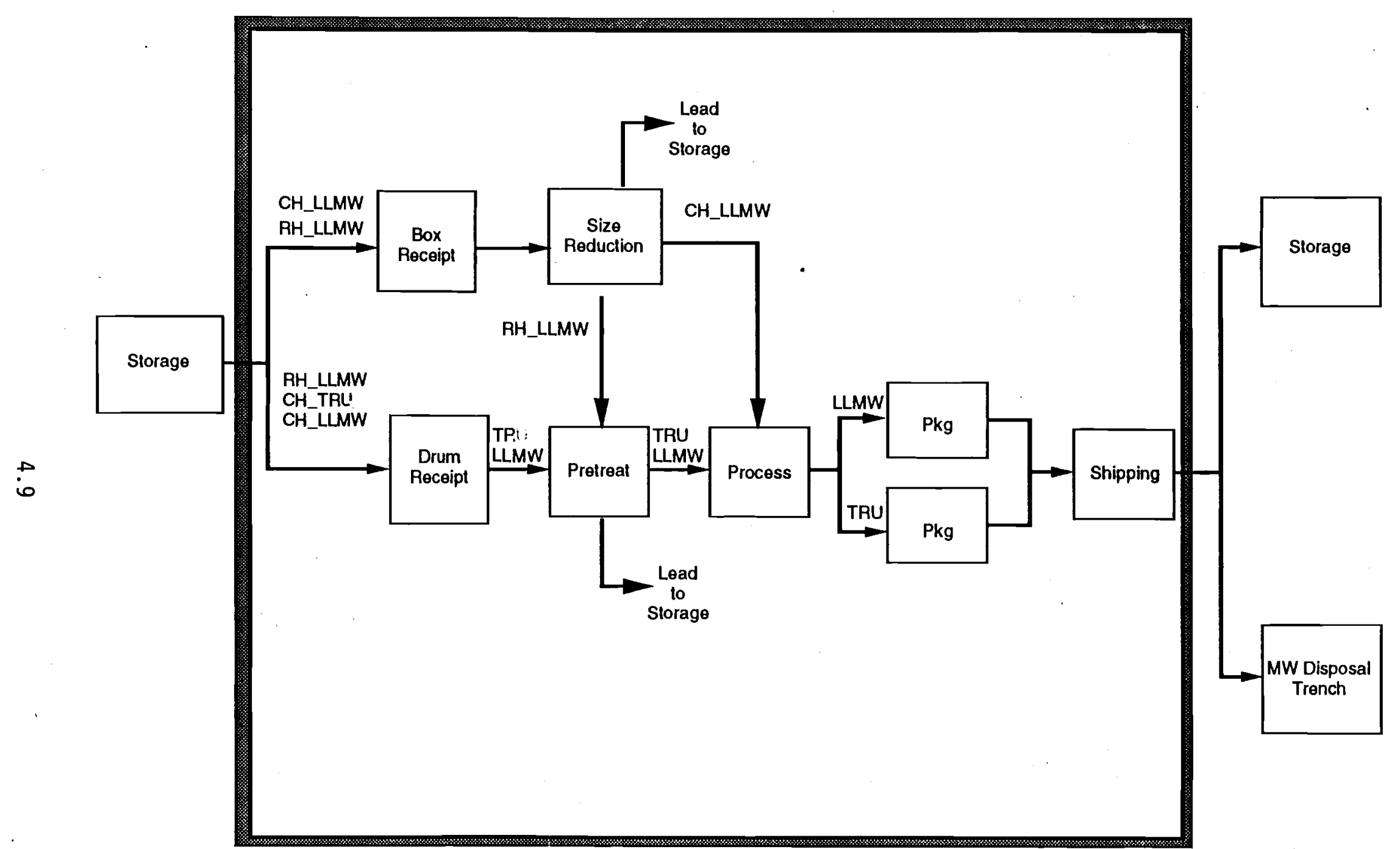

S9311046.5

FIGURE 4.4. Thermal Treatment Facility Waste Processing 
It is expected that some elements of the equipment will not be cleanable to the Debris Rule. The elements that are TRU waste will be cut up, characterized, and packaged for storage and eventual treatment in WRAP Module 2B. The elements that are LLMW will be treated using RCRA approved grouting treatments and will exit T-Plant for storage and disposal in the mixed waste trench. Once WRAP Module $2 B$ comes on-line, this stream of long equipment will be treated by both WRAP Module $2 B$ and the T-Plant until 2017, when T-Plant closes. WRAP Module $2 B$ will continue to treat this waste for the remaining years of solid waste operations. 


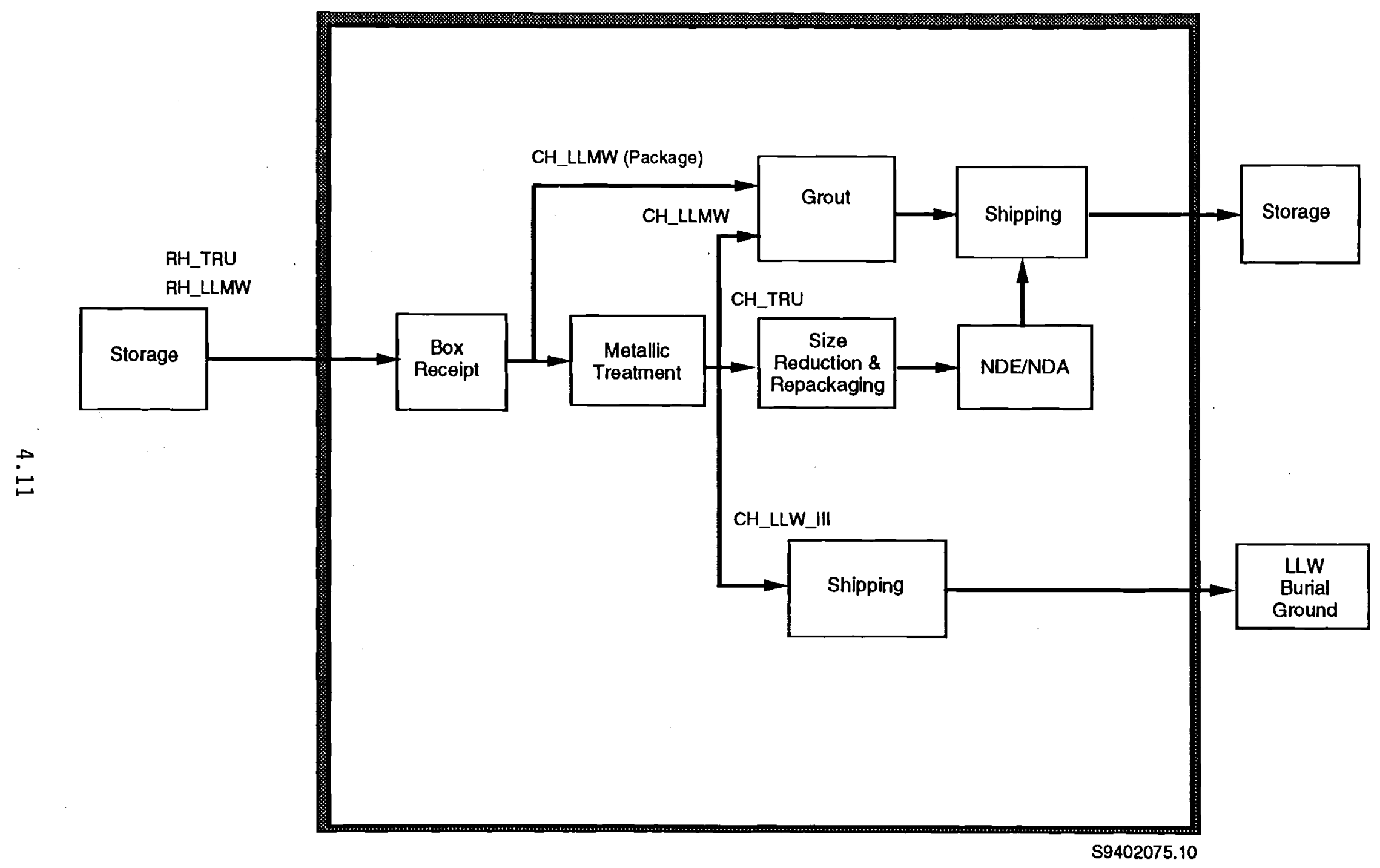

FIGURE 4.5. T-Plant Facility Waste Processing 


\subsection{DISPOSAL SITES}

Disposal sites are the final component of the system, and several sites are planned to provide disposal capacity for Hanford. Currently, one burial ground provides permanent disposal for $\mathrm{CH}_{-} \mathrm{LLW}$ _I and CH_LLW_III waste, and a mixed waste disposal trench is planned to provide disposal for CH_LLMW and RH_LLMW. Any TRU wastes will be sent to WIPP for disposal (see Table 2.3); the destination for GTCIII wastes has not yet been determined.

\subsection{WASTE ISOLATION PILOT PLANT}

Based on the latest planning at WIPP (November 1993), the facility will accept waste starting in 2000 for 20 years. With the emphasis on waste from the Rocky Flats Plant and the Idaho National Engineering Laboratory, it is assumed that the initial two years of WIPP operations will be devoted to addressing these wastes. This baseline assumes that waste will first be accepted by WIPP in 2002. The following wastes will be sent to WIPP:

- CH TRU waste that has been certified in WRAP Module 1 or WRAP Module 2B

- RH_TRU waste that has been certified in WRAP Module 2B.

TRUPACT-II containers will be used to ship CH_TRU to WIPP, while special remote-handled casks will be used for RH_TRU shipments. The current system assumes no transportation limits for waste shipments to WIPP.

Although the Draft Supplement Environmental Impact Statement for the Waste Isolation Pilot Plant (DOE 1989) asserts that the final waste acceptance year is 2013, it is widely understood that the closure date for WIPP will be extended to 2020. It is assumed that all Hanford retrieval activities and treatment facilities will be geared to meet this 2020 closure date.

\subsection{MIXED-WASTE DISPOSAL TRENCH}

The mixed-waste disposal trench will provide permanent onsite disposal for the following: 
- CH LLMW I and CH LLMW III, following treatment in WRAP Module 2A or the TTF $^{-}$and certífication in WRAP Module 1 or WRAP Module $2 \mathrm{~B}$.

- RH LLMW I and RH LLMW III following treatment and certification in the TTF $^{-}$or WRAP Module $2 \mathrm{~B}$.

The trench has a minimum design life of 50 years and an estimated capacity of $277,500 \mathrm{ft}^{3}$ (Carlson 1993). An assumption has been made for the baseline system that an infinite capacity exists for this trench. This will provide data to help determine if and when additional trenches will be required.

The following assumptions have been made:

- All unshielded RH LLMW I and RH LLMW III will be shipped to disposal from WRAP Mōdule-2B and the TTF.

- All CH_LLMW will be shipped to disposal from storage.

- This disposal site will be operational by 2000 (before WRAP Module $2 A$ commences operation).

\subsection{EXISTING LOW-LEVEL WASTE BURIAL SITE}

This onsite disposal trench is currently accepting CH_LLW_I and CH_LLW_III. CH_LLW_III is segregated from CH_LLW_I for protection and control in the unlined trench. This trench will also be accepting RH_LLW_I and RH_LLW_III from waste generators. It is assumed for the baseline system that an infinite capacity exists for this trench. This will provide data to help determine if and when additional trenches will be required for disposal of LLW. 


\subsection{WASTE STREAMS}

This chapter includes the waste stream flow diagrams, brief explanations for each of the flow diagrams, and the assumptions that have been used to form the basis for the system description and models. The assumptions listed for each waste stream were developed through discussions with WHC Cognizant Engineers in charge of the waste management facilities. Each flow diagram tracks a waste stream that will be managed by the three functions of storage, treatment, and disposal.

For simplicity, the individual storage facilities are combined into a single storage facility (see Figure 2.1 - "Storage Facilities"); this was done because the model cannot account for processing waste through the various storage modules $(2401,2402$, Phases I-IV, and Phase V) in any specified order.

The following sections are grouped by waste category, the method used in Section 4.0 of Valero et al. (1993). Further classification of each waste. category into waste streams is shown in Table 6.1. The rest of this chapter is divided into discussions of these waste streams. Two waste streams, CH_LLMW_GTCIII and CH_LLW_GTCIII, hive not yet been assigned treatment and disposal requirements. It can be assumed that these waste types will remain in long-term storage until the treatment is defined and available.

In the following sections, the figures will be found on the left-hand page and the text referring to it on the right-hand page. Figure 6.1 describes the symbols that are used in the waste stream diagrams. The symbols are used to define the specific flow patterns from waste generation/retrieval to final disposal. 
TABLE 6.1. Waste Categories and Their Corresponding Waste Streams

\begin{tabular}{|c|c|}
\hline Waste Category & Waste Stream \\
\hline \multirow[t]{6}{*}{ LLW } & Newly generated CH_LLW_I in drums \\
\hline & Newly generated CH_LLW_I in boxes \\
\hline & Newly generated and retrieved $\mathrm{CH}_{\text {_LLW_III in drums }}$ \\
\hline & $\begin{array}{l}\text { Newly generated and retrieved } C_{\text {CH_LLW_III in boxes and }} \\
\text { DST/SST equipment }\end{array}$ \\
\hline & Newly generated shielded RH_LLW_I and RH_LLW_III in drums \\
\hline & Newly generated shielded RH_LLW_I and RH_LLW_III in boxes \\
\hline \multirow[t]{4}{*}{ LLMW } & $\begin{array}{l}\text { Newly generated and retrieved } \mathrm{CH}_{-} \text {LLMW in drums and from } \\
\text { caissons }\end{array}$ \\
\hline & Newly generated CH_LLMW in boxes and DST/SST equipment \\
\hline & $\begin{array}{l}\text { Newly generated shielded RH_LLMW in drums and from } \\
\text { caissons }\end{array}$ \\
\hline & $\begin{array}{l}\text { Newly generated shielded RH_LLMW in boxes and DST/SST } \\
\text { equipment }\end{array}$ \\
\hline \multirow[t]{6}{*}{ TRU } & Retrieved $\mathrm{CH}$-TRU_SUSPECT in drums \\
\hline & Retrieved $\mathrm{CH}_{\text {_TRU_SUSPECT in boxes }}$ \\
\hline & Newly generated $\mathrm{CH}_{-}$TRU in drums and DST/SST equipment \\
\hline & Newly generated $\mathrm{CH}$ _TRU in boxes \\
\hline & $\begin{array}{l}\text { Newly generated shielded RH_TRU and retrieved } \\
\text { RH_TRU_SUSPECT in drums and in casks from caissons }\end{array}$ \\
\hline & $\begin{array}{l}\text { Newly generated shielded RH_TRU, DST/SST equipment and } \\
\text { retrieved RH_TRU_SUSPECT in boxes }\end{array}$ \\
\hline
\end{tabular}




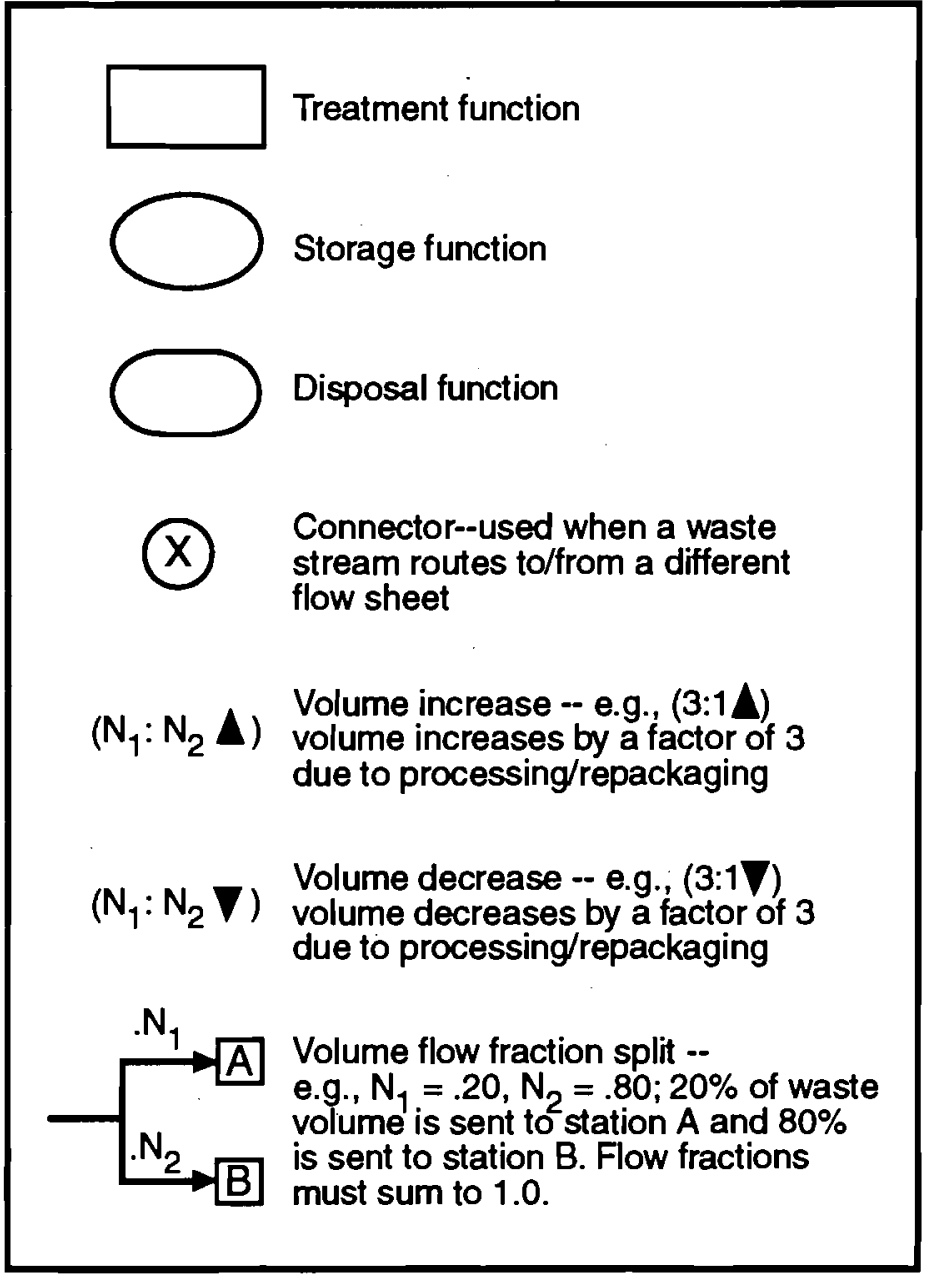

S9311046.6

FIGURE 6.1. Legend for Waste Stream Diagrams 


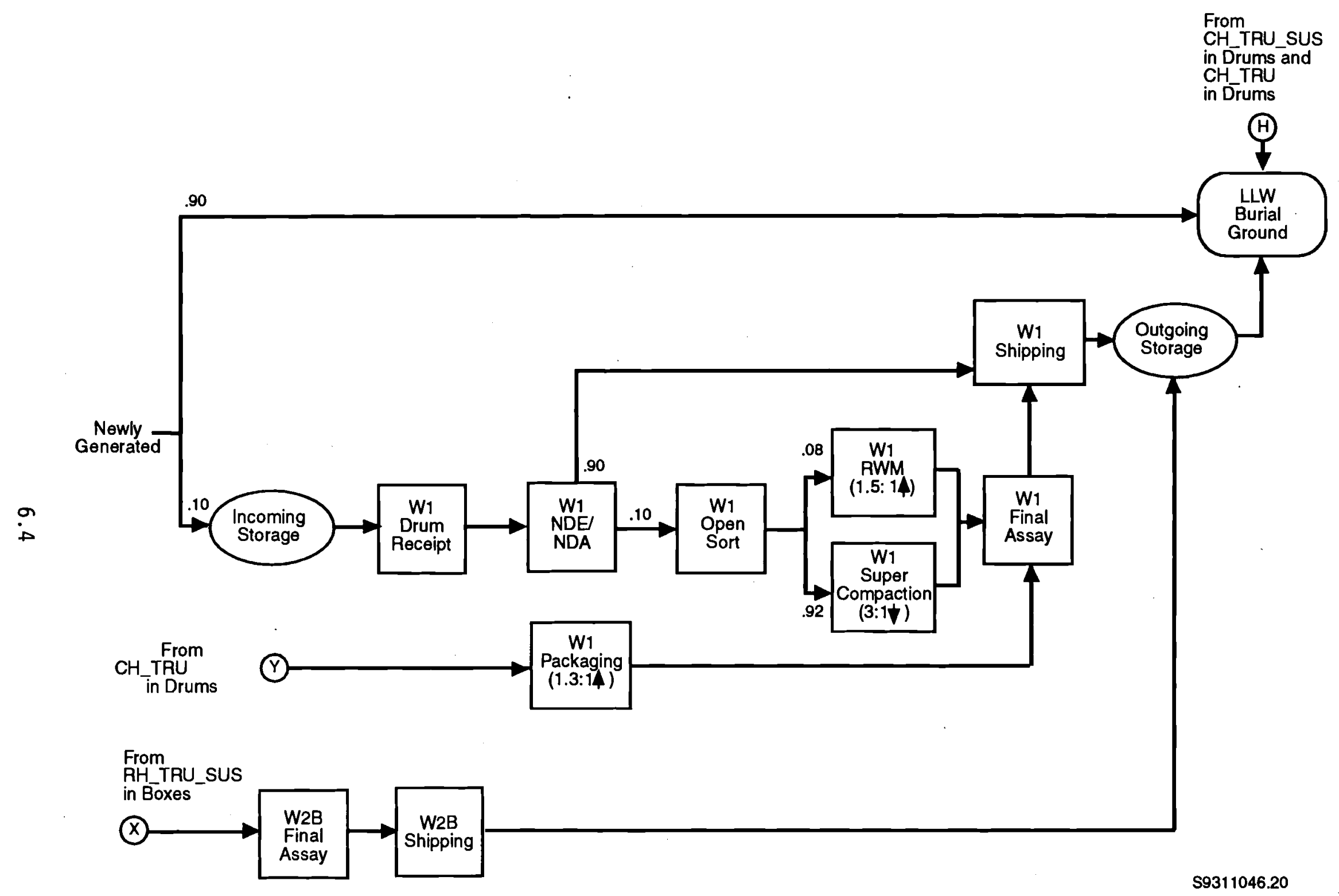

FIGURE 6.2. Newly Generated CH_LLW_I in Drums 


\subsection{LOW-LEVEL WASTE STREAMS}

\section{1 .1 Newly Generated CH_LLW I in Drums}

The current waste flow for CH_LLW_ is shown in Figure 6.2 . A $10 \%$ sample of the newly generated drums will be sent to storage and then routed to WRAP Module 1 for verification of contents, while the other $90 \%$ will remain at the generator until the lot is accepted. Upon acceptance, the entire waste stream will be shipped to burial.

\section{Assumptions}

- WRAP Module 1 will receive only $10 \%$ of all newly generated incoming waste for verification. The generator will hold the remainder of the batch at the generator facility until the waste lot is accepted, at which time the $90 \%$ fraction goes directly to the burial grounds. This verification plan will start when WRAP Module 1 commences operation.

- The $10 \%$ fraction goes to NDE/NDA and, of that fraction, $10 \%$ (1\% of the total) is routed to open-sort. of that reaching open-sort, $8 \%$ is assumed to go to RWM, with an output volume increase, including packaging aspects, of $1.5: 1$. The remaining $92 \%$ goes to supercompaction for a net $3: 1$ volume decrease.

- It is assumed that all newly generated waste will pass the acceptance criteria.

- See Appendix B for volume fraction calculations on this particular waste stream. 


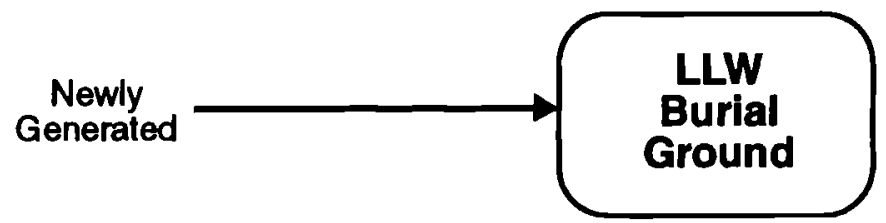

59311046.18

FIGURE 6.3. Newly Generated CH_LLW_I in Boxes 


\subsubsection{Newly Generated CH LLW I in Boxes}

It is assumed that this waste stream is sent directly to burial from the waste generators and that no verification examination of these volumes is required. See Figure 6.3. 


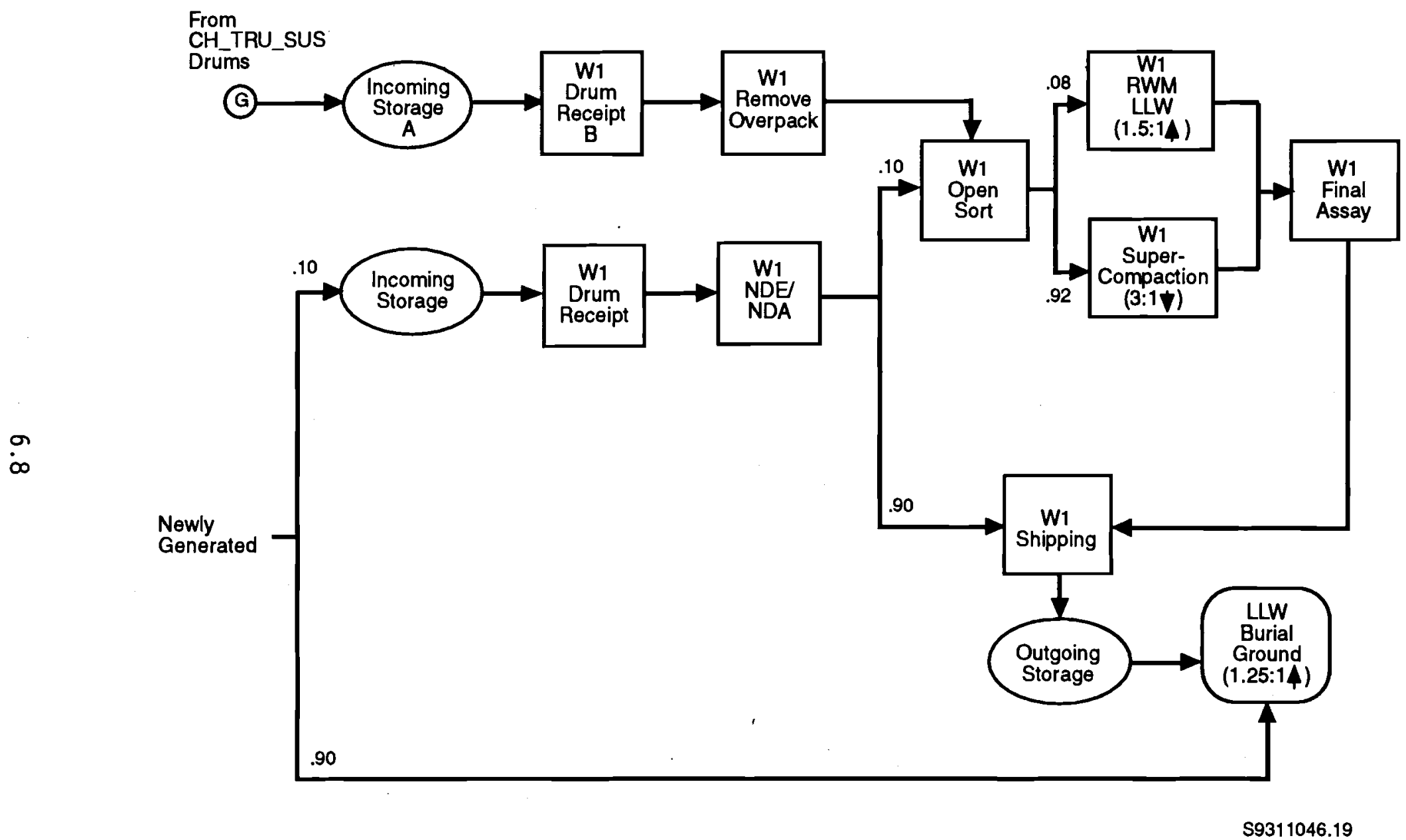

FIGURE 6.4. Newly Generated and Retrieved CH_LLW_III in Drums 


\subsubsection{Newly Generated and Retrieved CH_LLW III in Drums}

The waste flow for CH_LLW_III is shown in Figure 6.4. WRAP Module 1 will verify a sample of newly generated drums, while the remaining waste is held by the generator. Upon acceptance, the waste is shipped to burial.

The retrieved drums that assay as CH_LLW_III at the trench will be sent to Phase $V$ and then to WRAP Module 1 for processing and a final assay. After assay, the waste will be returned to storage to be routed to onsite burial.

See Appendix B for volume fraction calculations for $\mathrm{CH}_{-} \mathrm{LLW}$ in drums.

\section{As sumptions for Newly Generated Waste}

- WRAP Module 1 will receive only $10 \%$ of all newly generated drums for verification, while the generator holds the remainder of the batch at the generator facility until the waste lot is accepted. Once accepted, the $90 \%$ fraction goes directly to the LLW III burial grounds. This verification plan will start when WRAP Module 1 commences operation.

- The $10 \%$ fraction of newly generated incoming waste goes to NDE/NDA and, of that fraction, $10 \%$ ( $1 \%$ of the total) is routed to opensort. Of that reaching open-sort, $8 \%$ is assumed to go to RWM, with an output volume increase, including packaging aspects, of 1.5:1. The remaining 92\% goes to supercompaction for a net 3:1 volume decrease.

- It is assumed that all newly generated waste will pass the acceptance criteria.

- Per current planning, the LLW III is routed to the LLW trench. For volume identification purposes only, the disposal of LLW III is segregated into a special LLW III trench. The volume identification may be useful if later dāta suggest treatment may be required.

- Al1 CH LLW_III is assumed to be packaged into High Integrity Containers (HICs) at the burial ground, increasing the volume by a factor of $1.25: 1$.

\section{Assumptions for Retrieved Waste}

- Retrieval will perform a head gas sample and NDE/NDA examinations. The historical data, retrieval data, and processing activities performed in WRAP Module 1, will determine the basic splits among 
1) TRU, 2) LLW, and 3) LLMW. Based on current data, it is assumed that the TRU fraction is $50 \%$, the LLW fraction is $40 \%$, and the LLMW fraction is $10 \%$

- After trench operations, the overpacked drums will be sent to storage. The trench verification is assumed to be adequate for any WDOE-permitted storage data requirements.

- Waste arriving in WRAP Module 1 will have the overpack removed and be routed to open-sort. The WRAP Module 1 SDRD assumes that $92 \%$ of the waste will be supercompacted (after being placed in new drums) with a net $3: 1$ volume reduction.

The SDRD has $8 \%$ of the stream entering the RWM process, with a net volume increase of $1.5: 1$ (for this fraction).

The LLW departs to storage for final routing to the burial grounds. For volume identification purposes only, the disposal of LLW III is segregated into a special LLW_III trench. The volume identification may be useful if later data suggest treatment may be required.

- SWITS data show a small amount of LLW III stored in above-ground buildings. This LLW III is not currenttly permitted to be buried in shallow land burial grounds because it contains some organic compounds now restricted from burial. This small volume is being treated as LLMW. 
Intentionally left blank

6.11 


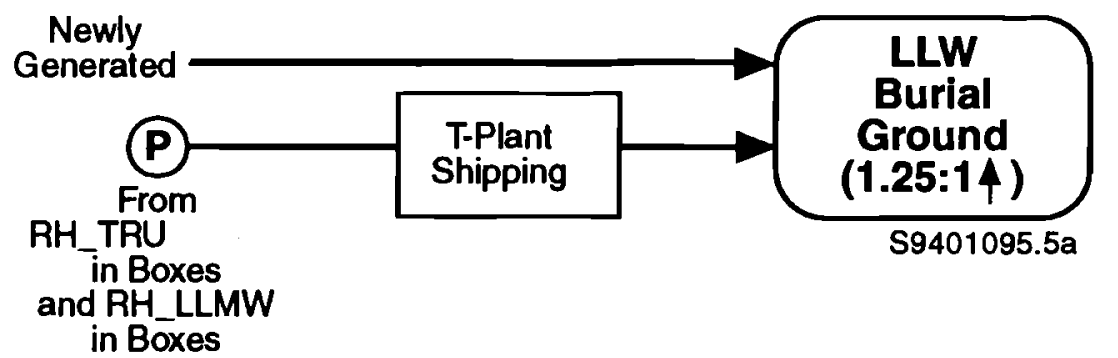

FIGURE 6.5. Newly Generated and Retrieved CH_LLW_III in Boxes and DST/SST Equipment 
6.1.4 Newly Generated and Retrieved CH_LLW_III in Boxes and DST/SST Equipment

It is assumed that this waste stream is sent directly to burial from the waste generators and that no verification examination of these volumes is required. See Figure 6.5. The $\mathrm{CH}_{-} L L W_{-} I I I$ will be packaged into HICs at the burial ground, increasing the volume by a factor of 1.25:1. A fraction of the DST and SST waste is assumed to assay as LLW after processing in T-Plant. This stream will exit T-Plant and go directly to the burial ground. 


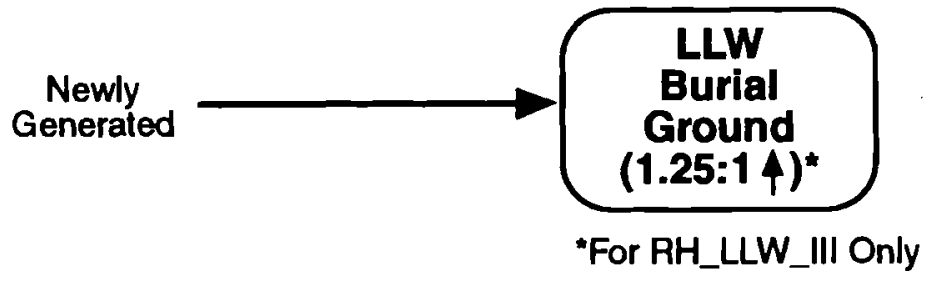

S9401095.5

FIGURE 6.6. New1y Generated Shielded RH_LLW_I and RH_LLW_III in Drums and Boxes 
6.1.5 New7y Generated Shielded RH_LLW_I and RH_LLW_III in Drums and Boxes

It is assumed that the RH_LLW_I and RH_LLW_III are sent directly to burial from the waste generators and that no verification examination of these volumes is required. See Figure 6.6. The RH_LLW_III will be packaged into HICs at the burial ground, increasing the volume by a factor of 1.25:1. 


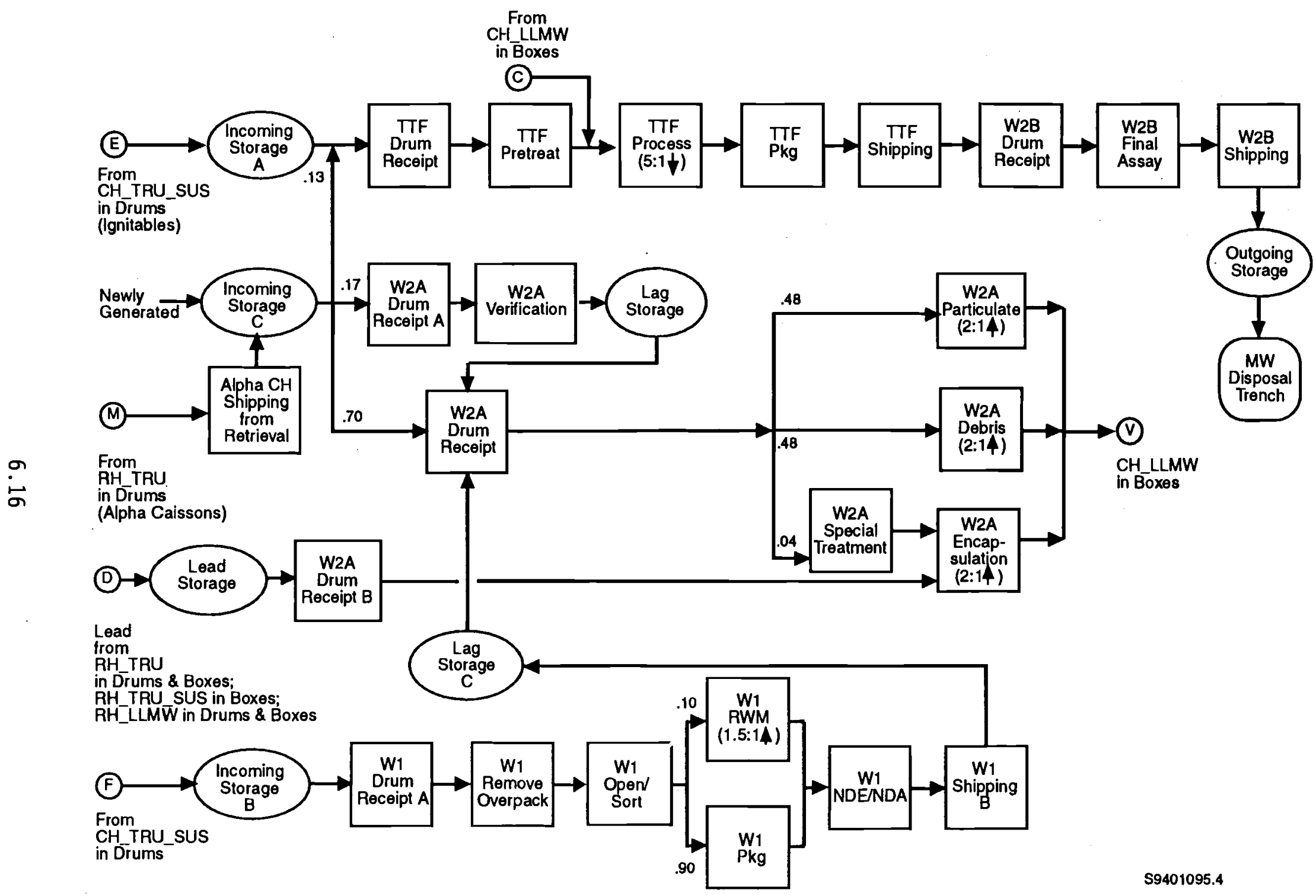

FIGURE 6.7. Newly Generated and Retrieved CH_LLMW in Drums and Caissons 


\subsection{LOW-LEVEL MIXED-WASTE STREAMS}

\subsubsection{Newly Generated and Retrieved CH LLMW in Drums and Caissons}

Newly generated and retrieved $\mathrm{CH}_{-}$LLMW in drums is treated by either WRAP Module $2 A$ or the TTF (see Figure 6.7). Waste that does not require thermal treatment will be routed through WRAP Module $2 A$ for treatment as either debris or particulate. Special streams with small volumes (such as mercury, lead, and containerized liquids) will also be treated by WRAP Module 2A. After being sent to storage, WRAP Module 1 will perform NDE/NDA on a sample of the waste. Assuming the entire lot is accepted, the waste is shipped to burial via storage.

The TTF will treat that fraction of the overall stream volume that requires thermal treatment. After treatment, the waste is sent to WRAP Module 2B for a final assay. The waste is assumed to be accepted, and the entire batch is routed to disposal from storage.

\section{Assumptions for Newly Generated Waste}

- The newly generated waste stream is processed in the WRAP Module $2 A$ facility or the TTF, depending upon the hazardous and physical matrix of the waste. For modeling purposes only, naither of these two facilities are concerned with isolation of LLMW_I and LLMW III; therefore, the LLMW feedstreams are combined into one stream, LLMW.

- The majority of the waste will be routed to WRAP Module $2 A$, assumed to be $87 \%$ of the total volume; the remaining $13 \%$ will be treated in the TTF. This split is based on analysis of the LLMW hazardous and physical characteristics contained in the 1992 Forecast database (Version 1.4).

- A $20 \%$ fraction of any drums entering WRAP Module $2 A$ will be sent to WRAP Module $2 A$ to verify that the container contents match the manifest prior to sending the entire batch.

- WRAP Module $2 A$ has three basic treatments: particulate treatment, debris treatment (primarily vibratory cement, but polymerization is optional), and special treatment (amalgamation and encapsulation treatments). The overall processing volume increase in WRAP Module $2 A$ is $2: 1$, resulting from treatment.

- The output of all waste is in $4^{\prime} \times 4^{\prime} \times 4^{\prime}$ boxes.

- The TTF (and any CTTF feeds, should the CTTF be operational) will treat $13 \%$ of the LLMW. The thermal treatment process will result in a net overall 5:1 volume reduction. The 5:1 reduction is very 
low for normal incinerator-type operations, but was selected because a high fraction of the TTF stream is non-combustible (e.g., contaminated metals).

- After thermal treatment, the glass slag product will be packaged and routed to WRAP Module 2B for a final assay. After assay, the waste is sent to the mixed waste disposal trench from outgoing storage. This differs somewhat from earlier WRAP Module 2A feedstock planning because of a change in treatment. With incineration, the ash was sent to WRAP Module 2A for immobilization. However, with a plasma arc furnace, a glass slag is produced which can be packaged internal to the TTF.

Assumptions for Retrieved Waste

- A fraction of the retrieved suspect TRU waste will be LLW/LLMW. The SDRD does not address the LLMW fraction of the LLMW/LLW split. The SWPM will assume the normally accepted $20 \%$ fraction (10\% of the total suspect volume) pending further data acquisition on this value. It is further assumed that the waste is repackaged for storage into overpack drums.

- The waste will be sent from storage to the WRAP Module 1 facility, where LLMW will share the open-sort station with the LLW in WRAP Module 1. The open-sort operations will be staged to prevent cross-contamination of the glovebox. (The techniques for preventing cross-contamination are outside the scope of this survey.)

The SWPM will also assume that 1) the 10\% RWM fraction will apply to LLMW, but 2) within the WRAP Module 1 open-sort-packaging operations, no compaction of the LLMW stream will occur (since compaction is not an acceptable pretreatment to WRAP Module $2 \mathrm{~A}$ processes). The $90 \%$ fraction is packaged and routed to storage and WRAP Module 2A for further treatment.

\section{Assumptions for 200W Alpha Caissons}

- Waste from the $200 \mathrm{~W}$ alpha caissons will be packaged into drums during retrieval operations. Within the retrieval operations, the plastic wrap used during the emplacement process will be segregated from the real waste. The real waste is assumed to be RH TRU and is estimated to be about $50 \%$ of the total volume. It is also assumed that some of the real waste containers have breached and that some of the plastic has become contaminated with the hot cell waste. Accordingly, pending data from the caissons, the SWPM will assume a distribution of $25 \% \mathrm{CH}$ LLMW, 25\% RH LLMW, and $50 \% \mathrm{RH}$ TRU. The $\mathrm{CH}$ LLMW from the caissons are routed to WRAP Module $\overline{2} \mathrm{~A}$ and follow the same flow path as newly generated LLMW. 
Intentionally left blank

6.19 


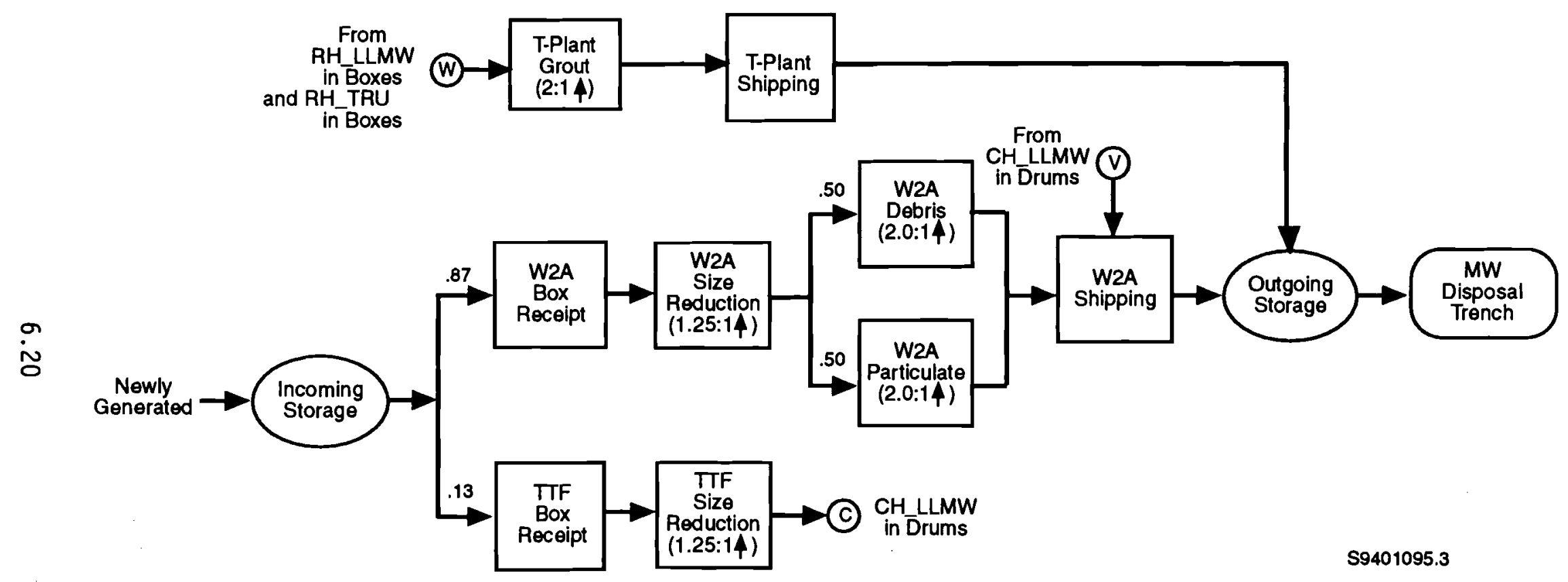

FIGURE 6.8. Newly Generated CH_LLMW in Boxes and DST/SST Equipment 


\subsubsection{Newly Generated CH_LLMW in Boxes and DST/SST Equipment}

CH_LLMW in boxes is received in Phase $V$ storage and sent to either WRAP Module $2 \mathrm{~A}$ or the TTF based upon the physical characteristics and hazardous constituents in the waste (see Figure 6.8). Both WRAP Module $2 \mathrm{~A}$ and the TTF perform a size-reduction operation. The waste is then treated identically to the CH_LLMW in drums presented in Section 6.2.1.

Assumptions for Newly Generated Waste

- For modeling purposes only, WRAP Module $2 A$ is not concerned with isolation of LLMW_I and LLMW_III, the LLMW feedstreams are combined into one stream, LLMW.

- The majority of the waste will be routed to WRAP Module 2A, assumed to be $87 \%$ of the total volume; the remaining $13 \%$ will be treated in the TTF.

- WHC-EP-0063 (DOE 1991) requires the packaging of waste into boxes that do not exceed the acceptable geometric and mass 1 imits for WRAP Module 2A. The geometric limits are $5 \times 5 \times 9 \mathrm{ft}$, with a mass limit of 12,000 1bm. (It is assumed that any boxes that exceed these limits are so rare as not to impact the SWPM results; they will be processed initially in WRAP Module 2B for size-reduction, followed by mixed waste processing in WRAP Module 2A.)

- The boxes routed to WRAP Module $2 A$ will be size-reduced, increasing the volume by a factor of $1.25: 1$.

- Processing of the waste as either debris or particulate will increase the volume by a factor of 2.0:1.

- The TTF processes will result in an initial volume increase of 1.25:1 for size-reduction. This waste will then be handled as newly generated LLMW in drums.

\section{Assumptions for DST/SST Equipment}

- Waste leaving T-Plant as CH_LLMW is $4 \times 4 \times 4 \mathrm{ft}$ boxes will exit to the LLMW trench after storaḡe. 


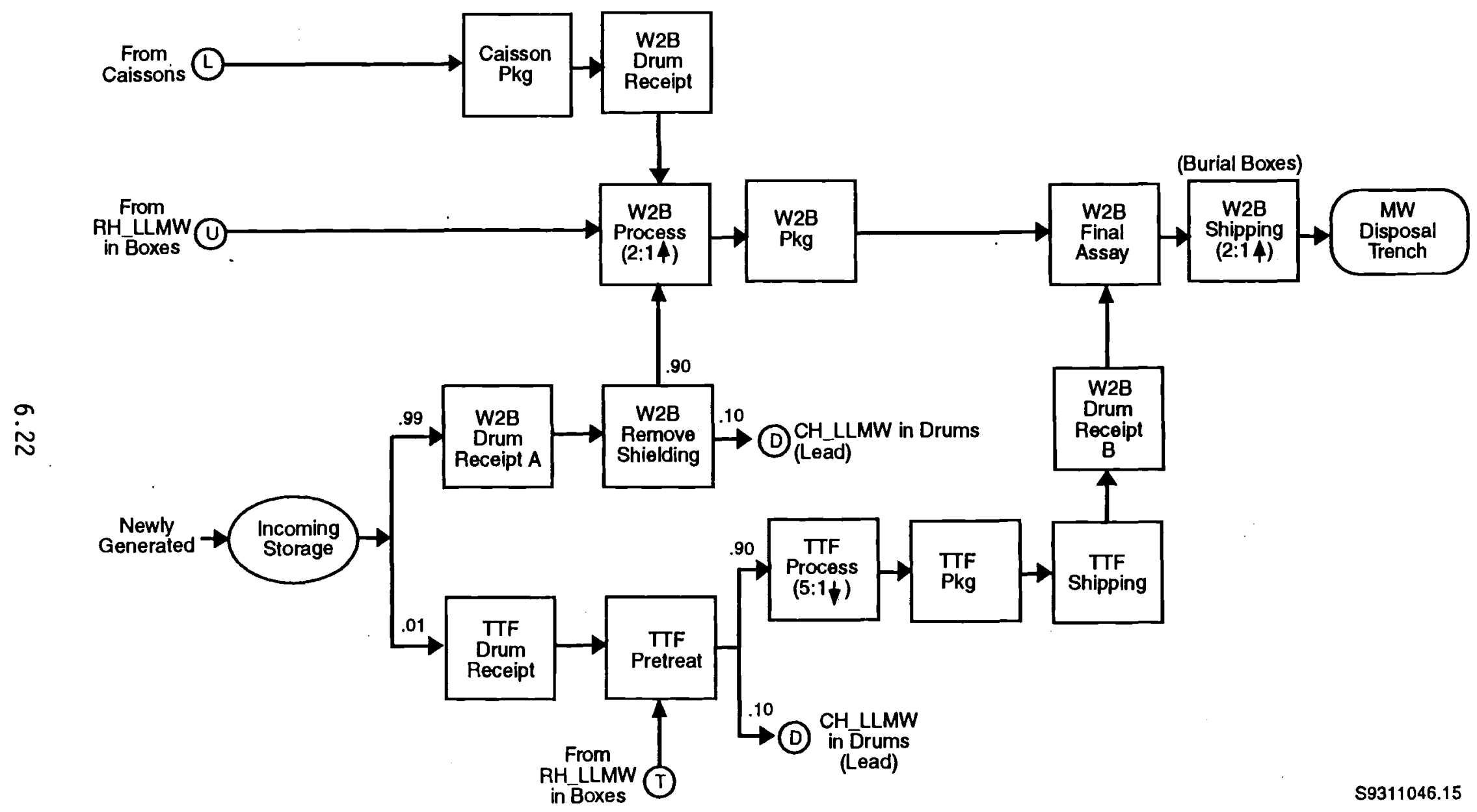

FIGURE 6.9. Newly Generated Shielded RH_LLMW in Drums and Caissons 


\subsubsection{Newly Generated Shielded RH LLMW in Drums and Caissons}

The current flow diagram for shielded RH_LLMW in drums is shown in Figure 6.9. The waste stream is primarily processed in WRAP Module 2B; however, a smal1 fraction of the stream (estimated at $1 \%$ ) will be treated at the TTF.

\section{Assumptions for Newly Generated Waste}

- These assumptions address both RH_LLMW_I and RH_LLMW_III.

- Pending data on actual and future operations, it is assumed that the generators report shielded waste volumes, with $10 \%$ being shielding and $90 \%$ being actual waste. The shielding is assumed to be lead.

- After storage, the waste will be directed to either WRAP Module 2B or the TTF. Pending acquisition of better data, it is assumed that $99 \%$ goes to WRAP Module $2 B$ and $1 \%$ goes to the TTF.

- After receipt and removal in the treatment plant, the lead is routed to WRAP Module $2 A$ for treatment.

- Waste sent to WRAP Module $2 B$ will be processed similar to that in WRAP Module 2A, resulting in a 2:1 volume increase. The waste routed to TTF is assumed to be treated in a thermal process (1ike a slagging incinerator) that provides an overa11 5:1 reduction in volume.

- After processing, the waste in WRAP Module $2 B$ is shipped directly to burial without any shielding internal to the drums. Assume a 2:1 overall volume increase due to burial box volumes.

- After TTF processing, a 10\% sample is sent to WRAP Module 2B for final assay, and upon acceptance the entire batch is shipped directly to burial.

\section{Assumptions from 200W Alpha Caissons}

- Waste from the $200 \mathrm{~W}$ alpha caissons is assumed to be $25 \% \mathrm{CH}$ LLMW, 25\% RH LLMW, and 50\% RH TRU. The RH_LLMW from the caissons is shipped to WRAP Module $\overline{2} B$ in a dedicāted RH drum cask. The cask is not modeled in the SWPM. In WRAP Module 2B, the RH_LLMW caisson waste is treated as newly generated waste. 

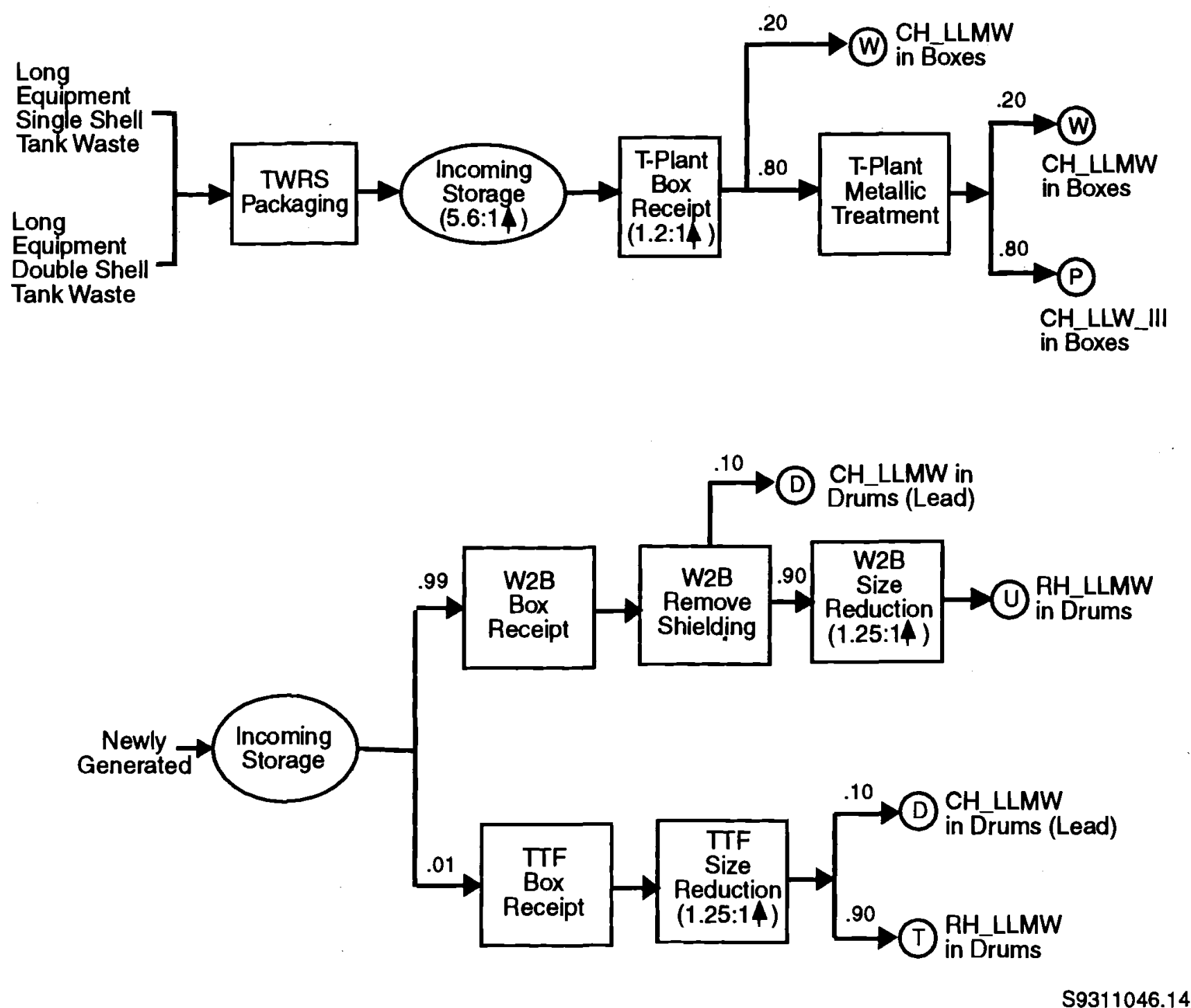

FIGURE 6.10. Newly Generated Shielded RH_LLMW Boxes and DST/SST Equipment 


\subsubsection{Newly Generated Shielded RH_LLMW in Boxes and DST/SST Equipment}

This stream is processed in either WRAP Module 2B or the TTF depending upon its hazardous constituents (see Figure 6.10). RH_LLMW is size-reduced in either facility, receives treatment, and is shipped to disposal. The removed lead shielding is sent to WRAP Module $2 A$ for encapsulation. The long equipment RH_LLMW from the DST and SST cleanout operations will be processed in the T-Plant and/or WRAP Module 2B.

\section{Assumptions for Newly Generated Waste}

- These assumptions address both RH_LLMW_I and RH_LLMW_III.

- Pending data on actual and future operations, it is assumed that the generators report shielded waste volumes, with $10 \%$ being shielding and $90 \%$ being actual waste. The shielding is assumed to be lead.

- After storage, the waste will be directed to either WRAP Module 2B or TTF. Pending acquisition of better data, it is assumed that $99 \%$ goes to WRAP Module 2B and $1 \%$ goes to the TTF.

- After receipt and removal in the treatment plant, the lead is routed to WRAP Module 2A for treatment.

- The RH LLMW boxes receive a size-reduction in WRAP Module 2B and the TTF, increasing the volume by a factor of $1.25: 1$. The waste is then handled as newly generated LLMW in drums, as described in Section 6.2.3.

\section{Assumptions for DST/SST Equipment}

- These assumptions apply to just the long equipment coming from DST and SST cleanout operations. It is assumed that the waste, as packaged, wi11 be RH_LLMW.

- T-Plant is assumed to process this waste starting in 1996 and will discontinue operations in 2017. When WRAP Module 2B comes on line in 2009, this long equipment will be processed by both T-Plant and WRAP Module 2B. After T-Plant's closure in 2017, WRAP Module 2B will continue to treat this waste for the remaining years of solid waste operations.

- It is assumed that all DST/SST waste will be sent to CWC storage prior to treatment. The waste will be batched to the treatment plant from storage.

- It is assumed that the long components will be arriving in an envelope of plastic, the "flexible receiver." This flexible 
receiver constitutes a pretreatment volume increase of 1.2:1.

These flexible receivers will be processed within T-Plant to LLMW RCRA rules, using a shred-grout process that results in a $2: 1$ volume increase.

- It is assumed that treatment will be focused on addressing the waste under the EPA debris rule and that a great majority of the waste can be decontaminated and made releasable. Pending data from operations, assume that $80 \%$ of the waste will be cleaned to LLW_III levels and $20 \%$ will be CH_LLMW.

- The LLW_III resulting from treatment will be sent directly to burial.

- The CH LLMW will be treated using RCRA approved grouting treatments and wiTl be shipped to the mixed waste disposal trench.

- Processing of the CH_LLMW will result in a 2:1 volume increase factor.

- Scenario 7.1 does not include any potential impact of having the proposed MPSC facility operate on solid waste. 
Intentionally left blank 


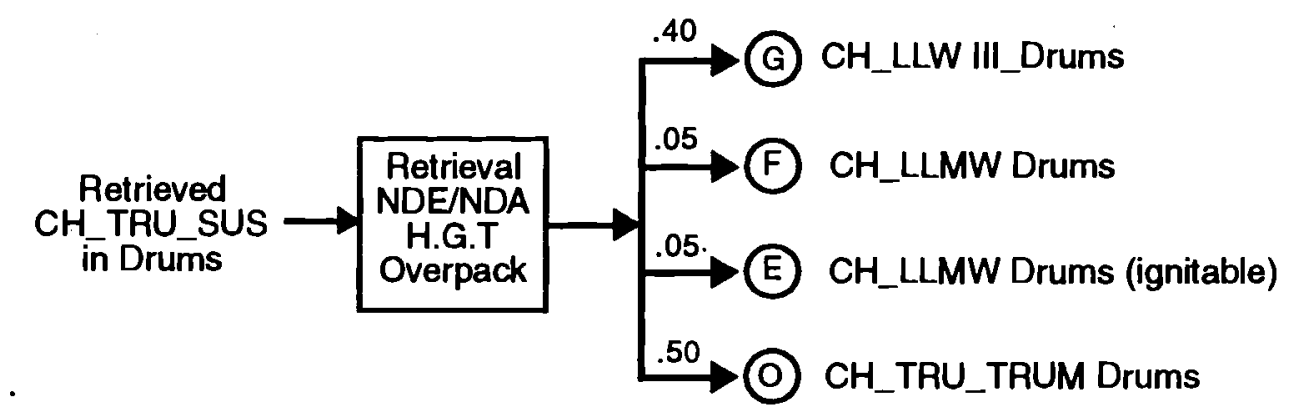

9

N

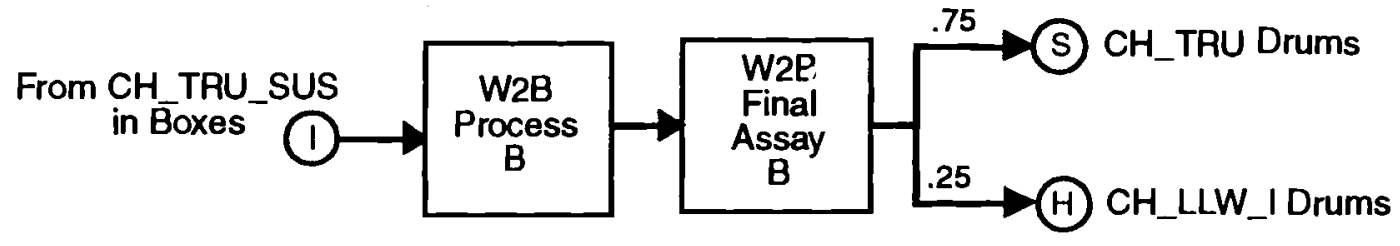

S9311046.13

FIGURE 6.11. Retrieved CH_TRU_SUSPECT in Drums 


\subsection{TRANSURANIC WASTE STREAMS}

\subsubsection{Retrieved CH TRU SUSPECT in Drums}

The waste is retrieved from the trenches and placed in overpacks (see Figure 6.11). As part of the retrieval process, the waste will receive a complete NDE/NDA examination to aid in precharacterizing it into LLW/LLMW and suspect TRU streams. A11 retrieved waste is sent to storage pending treatment. About $15 \%$ of the $\mathrm{CH}_{-}$TRU fraction (about $8 \%$ of the total retrieved volume) goes to WRAP Module 2B since it cannot be received in WRAP Module 1, and only $10 \%$ of the total retrieved volume goes to TTF as ignitable. The remaining waste is treated in WRAP Module 1. Detailed descriptions of these waste flows are described in the sections pertaining to LLW/LLMW and TRU. See Appendix $B$ for volume fraction calculations on this particular waste stream.

\section{Assumptions}

- Retrieval will perform a head gas sample and NDE/NDA examinations. The historical data, plus that obtained in these tests, will determine the basic splits between (1) TRU, (2) LLW and (3) LLMW. Based on current data, the TRU fraction is $50 \%$, the LLW fraction is $30 \%$ and the LLMW fraction is $20 \%$.

- Retrieval will provide an 85-gallon overpack for the drums, which will not be included in the model runs.

- The overpacked drums will be sent to storage. The trench verification is assumed to be adequate for any WDOE-permitted storage data requirements.

- Pending data acquisition, it is assumed that the LLW in retrievable storage is LLW III (since it is "suspect TRU," it is more likely to have a higher àctivity level than most LLW).

- It is assumed that techniques will be available to segregate the incoming LLW into LLW and LLMW streams. The techniques used in this segregation are outside the scope of this study.

- CH TRU SUSPECT in boxes will be repackaged into drums. It is assumed that there are in-process assay stations that permit inprocess screening of the waste into TRU and LLW categories and for packaging the TRU waste into drums while maintaining the gram loading limits.

- Pending more refined data than is available in WHC-EP-0225, it is assumed that the final assay splits the total drum output volume into a $25 \%$ fraction of LLW and a $75 \%$ fraction of TRU. It is 
further assumed the $25 \%$ LLW fraction consists principally of box material wastes and is categorized as LLW I and that none of the LLW is LLMW. See the CH TRU and the CH LEW I flow sheets for specific routings.

- The 75\% TRU fraction is based on a review of the information contained in WHC-EP-0225 in which the boxes show a very high percentage of TRU. The data suggest that the box contents might be in the range of $82 \%$ TRU, but with the volume increases included in the analysis, a factor of $75 \%$ is deemed appropriate for the repackaged waste. 
Intentionally left blank 


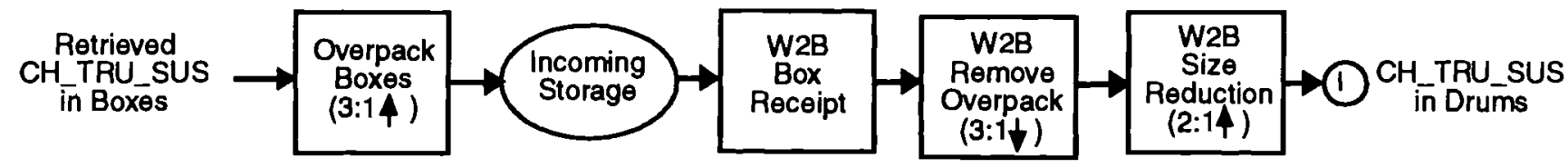

S9311046.12

FIGURE 6.12. Retrieved CH_TRU_SUSPECT in Boxes 


\subsubsection{Retrieved $\mathrm{CH}$ TRU SUSPECT in Boxes}

The waste is retrieved from the trenches and placed in overpacks (see Figure 6.12). The waste will then be sent to storage until WRAP Module 2B becomes available. The waste will be size-reduced, packaged into drums, and assayed in WRAP Module 2B. The waste will then be routed according to the CH_TRU and CH_LLW_I flow sheets.

Assumptions for Newly Generated Waste

- No NDE/NDA examinations or head gas testing are performed at retrieval.

- Retrieval will provide a customized overpack for the boxes. Based on an analysis performed by Central Engineering, the average overpack volume increase is 3:1 (see Appendix A).

- The overpacked boxes will be sent to storage without any verification overcheck.

- All boxes go to WRAP Module 2B for processing. At WRAP Module 2B, it is assumed that there will be a reduction in volume of $3: 1$ as the overpack is removed and than a $2: 1$ volume increase. The $2: 1$ factor is an engineering judgment based on a $2: 1$ volume increase related to size-reduction so that the waste can be packaged into drums. 


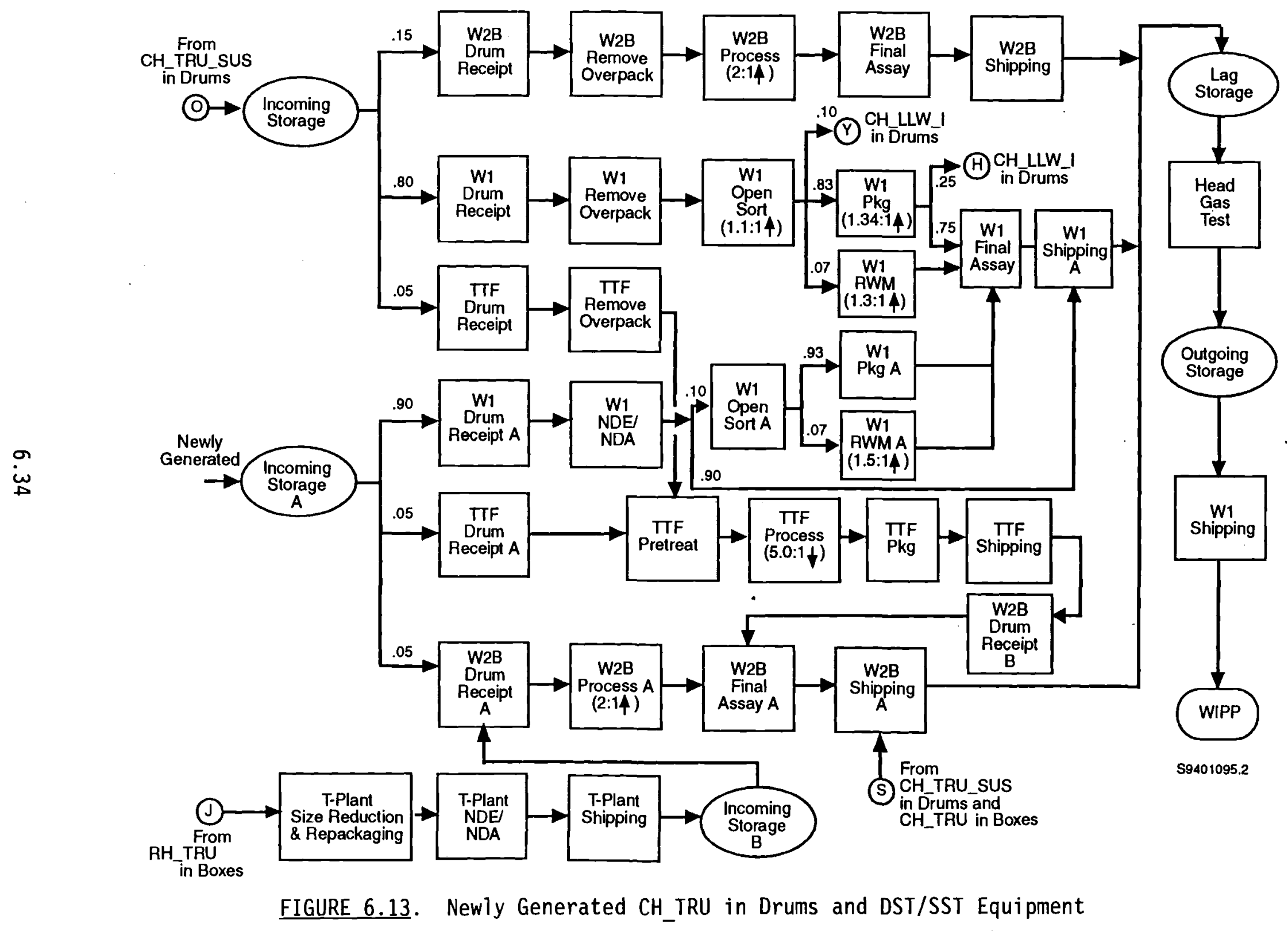




\subsubsection{Newly Generated $\mathrm{CH}$ TRU in Drums and DST/SST Equipment}

The $\mathrm{CH}_{-}$TRU in drums comes from waste generators and retrieved burial trenches and is sent to storage. Then, based on its hazardous constituents, it is sent to either WRAP Module 1, WRAP Module 2B, or the TTF (see Figure 6.13).

\section{Assumptions for Newly Generated Waste}

- It is assumed that the newly generated drums will be prepared by the generator to acceptable WIPP-WAC standards and that they will not have to be off-loaded for gram loading restrictions.

- Scenario 7.1 will neglect that current drums (now stored in TRUSAF) are loaded to earlier versions of the WIPP-WAC and will have to be off-loaded. It is assumed that this discrepancy between the model and the actual conditions is not significant to the larger result of overall TSD operations.

- The majority of newly generated CH_TRU is received in WRAP Module 1 for processing. The waste will be routed to the NDE/NDA station, from which a $10 \%$ sample will be sent through the open sort. The remaining $90 \%$ of the waste will be sent to storage. All CH TRU is routed through head gas testing in Phase $V$ prior to shipment to WIPP.

- Of the $10 \%$ fraction routed through open sort, $93 \%$ is assumed to be simply repackaged and $7 \%$ is assumed to require RWM treatment. Waste processed at the RWM station will increase in volume by a factor of $1.5: 1$. The waste is sent to final assay and shipped to storage where it waits for head gas testing and transport to WIPP.

\section{Assumptions for Retrieved Waste}

- Retrieved waste arriving in WRAP Module 1 will have the overpack removed and then be routed to open-sort. For TRU drums, the SDRD assumes that $7 \%$ will go to RWM (with a 2:1 increase) and that the remaining fraction ( $93 \%$ ) gets packaged either to the WIPP-WAC $(83 \%)$, with a net $1.34: 1$ volume increase, or that the drums themselves get packaged as LLW_I (7\%) with a net volume increase of $1.3: 1$. The drums containing the retrieved waste are classified as CH_LLW_I and buried. (See the calculation notes in Appendix B.)

\section{Assumptions for DST/SST Equipment}

- Waste leaving T-Plant as CH TRU will be routed to storage to await treatment in WRAP Module 2B prior to disposal at the WIPP. 


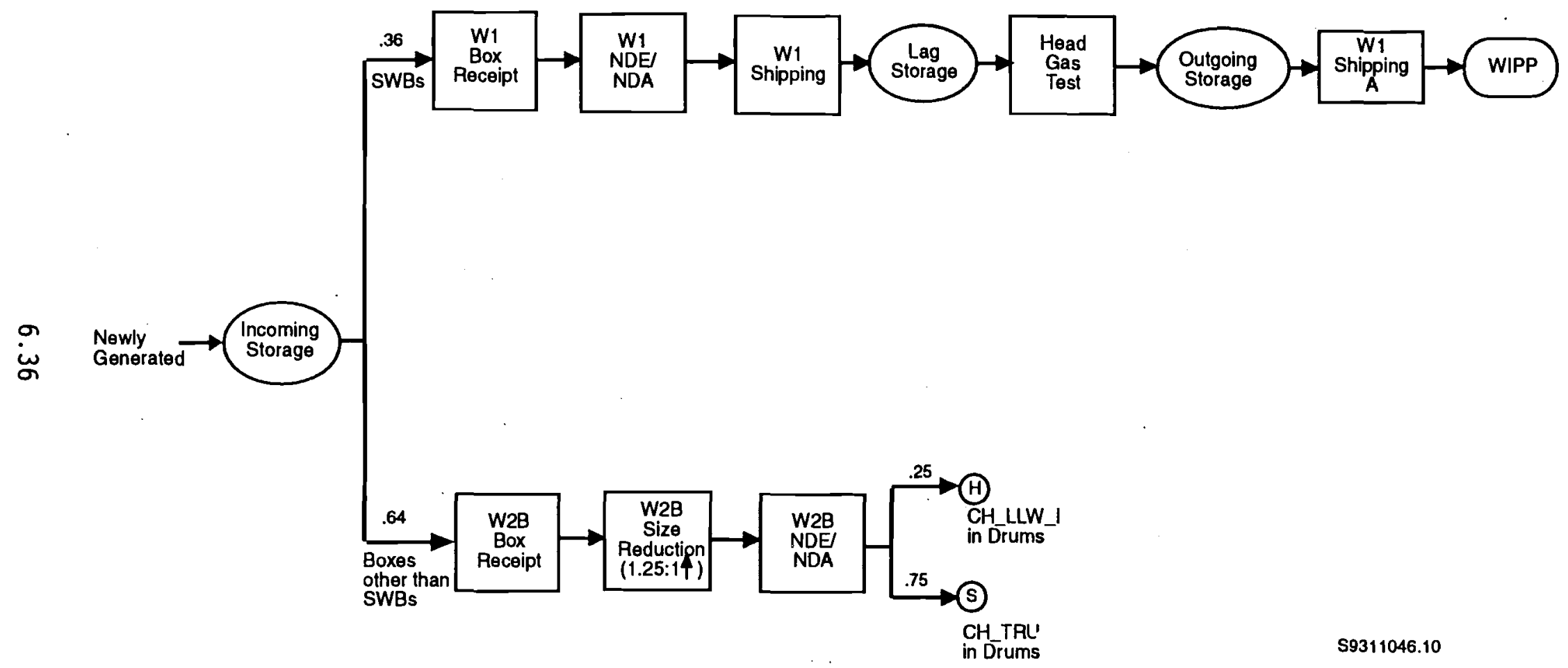

FIGURE 6.14. Newly Generated $\mathrm{CH}_{-}$TRU in Boxes 


\subsubsection{Newly Generated CH TRU in Boxes}

The waste is sent to storage from the waste generators (see Figure 6.14). From storage, waste in the SWBs is sent to WRAP Module 1 for examination and assay. After assay, the waste is sent to storage for head gas testing and is then transferred back to WRAP Module 1 for shipment to WIPP. Waste in other boxes is sent to WRAP Module $2 B$, where it is sizereduced, characterized, and packaged into drums. The drums are then sent to storage for head gas testing and shipment to WIPP.

Assumptions

- This group of waste includes that generated and packaged to the WIPP-WAC in SWBs and that placed in other boxes. The latter will require treatment in WRAP Module $2 B$.

- Newly generated TRU in SWBs are received in WRAP Module 1 for processing. For SWBs, it is assumed that the generators package the waste to the WIPP-WAC and all shipments are acceptable.

- The other I'RU in boxes are routed to Phase $V$ for storage pending processing in WRAP Module 2B.

- Once WRAP Module 2B becomes operational, the boxed TRU waste is batched into the facility, size-reduction occurs, and the waste is packaged into drums. WRAP Module 2B will have its own NDE/NDA capability and the drums leaving the facility will exit to Phase $V$, receive a head gas test, then exit to WIPP via WRAP Module 1 . The acts of removing the box from the waste and actual size-reducing operations necessary to get the waste into a form that can be packaged into drums are estimated to result in a net $1.25: 1$ volume increase.

- Pending additional data, it is assumed that WRAP Module $2 \mathrm{~B}$ will be able to segregate the box per se from the contained waste and the box will be classified as LLW_I. Pending some calculations or experimental data, it is assumed that $25 \%$ of the total box volume will exit as LLW_I (the box itself) and $75 \%$ of the total box volume will be TRU.

- Since this is newly generated waste, it is assumed that the waste contained in the box is correctly classified as TRU waste.

- It is assumed that the TRU waste has a contamination level similar to other TRU waste and that a net 2:1 volume increase occurs in processing the waste into drums while meeting TRUPACT-II gram loading limits.

- In current planning, all waste exiting WRAP Module $2 B$ is in drums. 


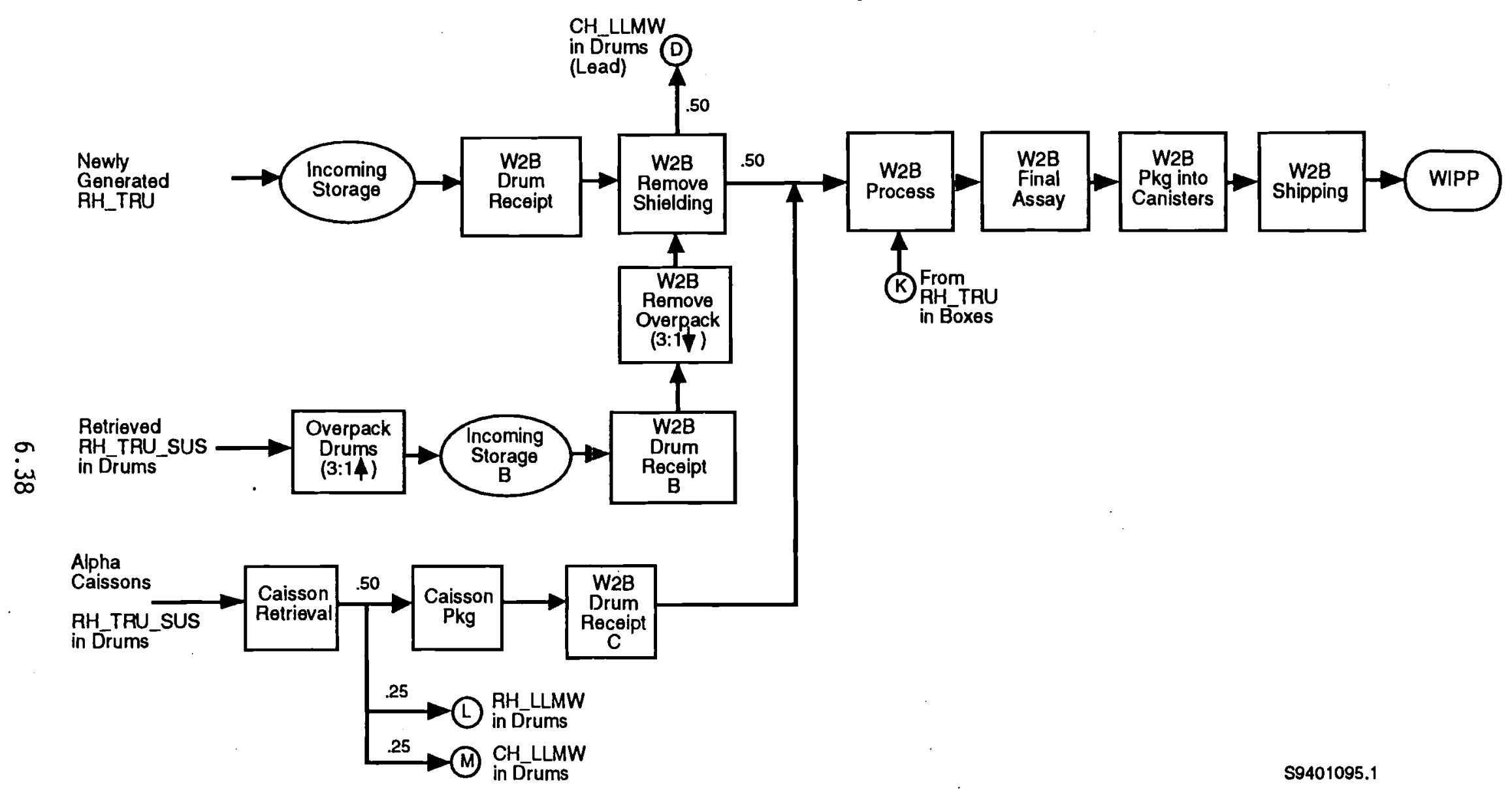

FIGURE 6.15. Newly Generated Shielded RH_TRU_TRUM and Retrieved RH_TRU_SUSPECT in Drums and in Casks from Caissons 


\subsubsection{Newly Generated Shielded RH TRU and Retrieved RH TRU SUSPECT in Drums and in Casks from Caissons}

This waste stream consists of newly generated waste, as well as retrieved waste from trenches and caissons (see Figure 6.15).

Assumptions for Newly Generated Waste

- It is assumed that this waste is, most likely, a result of glove box operations with irradiated fuel and materials. As such, this waste will be highly contaminated with TRU with a high radiation field. Accordingly, it is assumed that all this waste will be treated as TRU waste.

- Pending data on actual practices, it is assumed that for newly generated drums, the drums have internal shielding such that the actual waste volume is $50 \%$ of the total reported volume. The shielding (assumed to be lead) will be removed in the WRAP Module 2B processing operations and routed to WRAP Module 2A for final packaging.

- Final packaging in WRAP Module $2 \mathrm{~B}$ is assumed to be to the RH_TRU waste acceptance criteria. Pending this criteria and data on the contents of the containers, it is assumed that no volume increase results from this criteria as it applies to drums of waste. When the three drums are placed into the shipping canister, the net volume increase is $1.4: 1$.

- A11 RH_TRU waste is shipped from WRAP Module 2B directly to WIPP. Assumptions for Retrieved Waste

- This is also assumed to be hot-cell waste.

- For retrieved drums, it is assumed that retrieval will apply an overpack for transportation and storage. This 1 volume increase is assumed to be $3: 1$ (same as RH Boxes from trenches).

- The shielding volumes are removed in the WRAP Module $2 B$ processing operations and routed to WRAP Module 2A for final packaging. The TRU waste product is processed in WRAP Module $2 B$, sent to a final assay station, and packaged for shipment to WIPP.

- Final packaging in WRAP Module $2 B$ is assumed to be to the RH TRU waste acceptance criteria. Pending this criteria and data on the contents of the containers, it is assumed that no volume increase results from this criteria as it applies to drums of waste. When the three drums are placed into the shipping canister, the net volume increase is $1.4: 1$.

- A11 RH_TRU waste is shipped from WRAP Module $2 B$ directly to WIPP. 
- Scenario 7.1. does not include any potential impact of having the proposed Multipurpose Storage Complex (MPSC) facility operate on solid waste.

Assumptions for 200W Alpha Caissons

- Waste from the $200 \mathrm{~W}$ alpha caissons is assumed to be $25 \%$ CH LLMW, 25\% RH_LLMW, and 50\% RH_TRU. In WRAP Module 2B, the RH_TRU caisson waste is treated as newTy generated waste.

- The cask used in transporting the drums between the caisson and WRAP Module 2B is not modeled. 
Intentionally left blank

6.41 

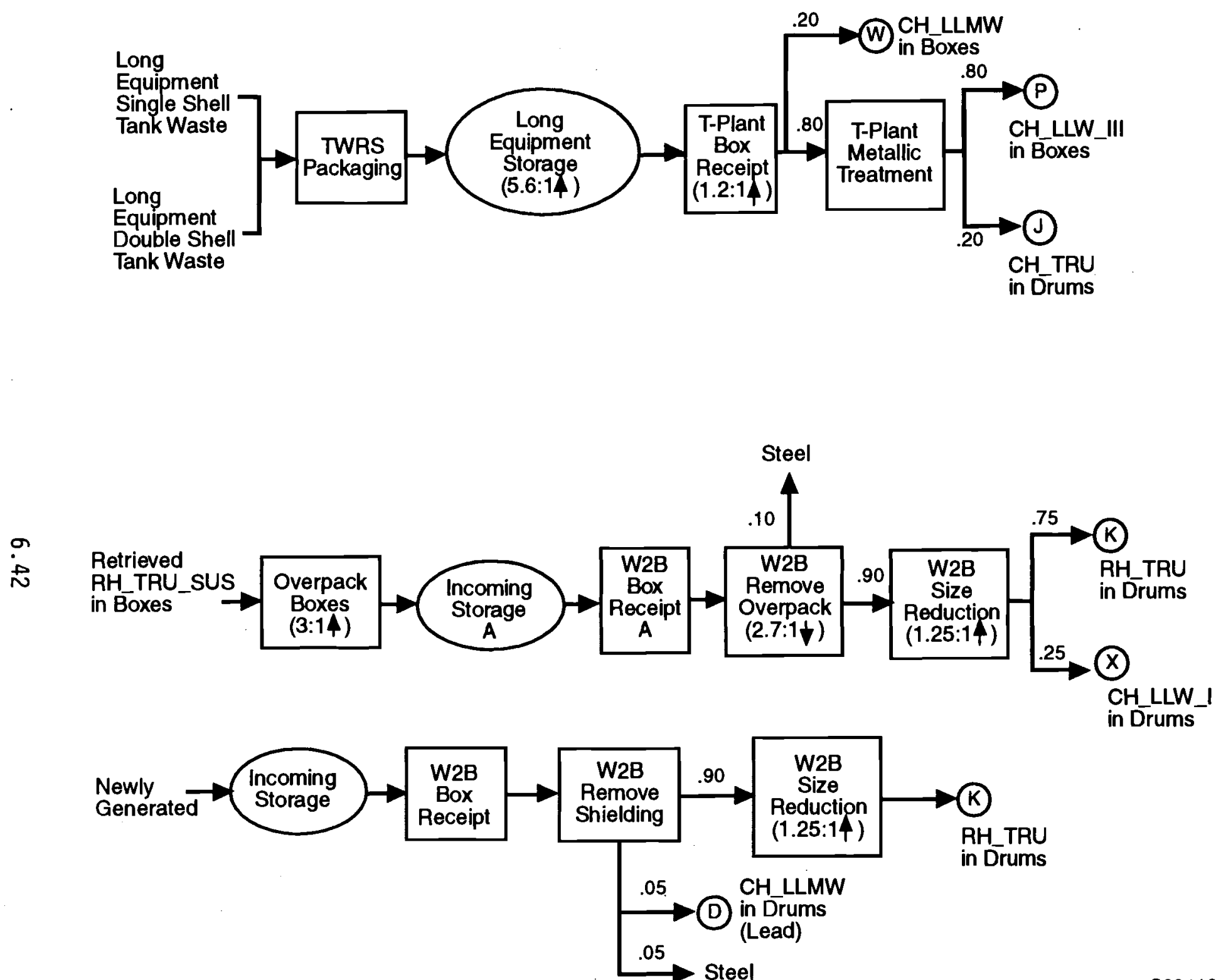

$\$ 9311046.8$

FIGURE 6.16. Newly Generated Shielded RH_TRU, DST/SST Equipment, and Retrieved RH_TRU_SUSPECT in Boxes 


\subsubsection{Newly Generated Shielded RH TRU, DST/SST Equipment, and Retrieved}

RH TRU SUSPECT in Boxes

This waste stream consists of newly generated waste, DST and SST equipment, and retrieved waste from trenches (see Figure 6.16). A fraction of this waste will be sent to storage until WRAP Module $2 B$ becomes operational and the remainder will go to T-Plant. In WRAP Module $2 B$, waste will be size-reduced, packaged into drums, processed, assayed, packaged into canisters, and shipped to WIPP.

\section{Assumptions for Newly Generated Waste}

- It is assumed that this waste is a result of glove box operations with irradiated fuel and materials, as well as equipment used in reprocessing of irradiated fuel. As such, this waste will be highly contaminated with TRU with a high radiation field. Accordingly, it is assumed that all this waste will be treated as TRU waste.

- Pending data on actual practices, it is assumed that for newly generated boxes, internal shielding will be added such that the actual waste is $90 \%$ and shielding is $10 \%$ of the total reported volume. Pending data from waste generators, it is assumed that the shielding applied to newly generated boxes is a 50:50 mix of steel and lead.

- Shielding volumes are removed in the WRAP Module $2 B$ processing operations and it is assumed that the lead is routed to WRAP Module $2 \mathrm{~A}$ for final packaging and the steel is decontaminated and released. The remaining TRU waste will be size-reduced and packaged into drums. The waste will then follow the flow as shown in Figure 6.15 for RH_TRU in drums.

\section{Assumptions for Retrieved Waste}

- For retrieved boxes, it is assumed that retrieval will apply shielding internal to the overpack for transportation and storage. The overall average volume increase due to the overpack is $3: 1$. It is assumed that the shielding adds $10 \%$ to the original waste volume, but that the shielding is contained within the overpack volumes. It is further assumed that the shielding is lead.

- Shielding volumes are removed in the WRAP Module 2B processing operations, and it is assumed that the lead is routed to WRAP Module 2A for final packaging. The waste will then be size-reduced and routed as shown on the RH TRU SUSPECT flow sheet for drums. It is assumed that the size-reduction processes needed to repackage the waste into drums provide a volume increase of 1.25:1. 
- The decontamination operations on steel shielding are not included in the model, although an initial estimate of the volume of steel shielding is included in the model.

- Scenario 7.1 does not include any potential impact of having the proposed MPSC facility operate on solid waste.

\section{Assumptions for DST/SST Equipment}

- These assumptions apply to just the long equipment coming from DST and SST cleanout operations. It is assumed that the waste, as packaged, will be RH_TRU.

- T-Plant is assumed to process this waste starting in 1996 and will discontinue operations in 2017. When WRAP Module 2B comes on line in 2009, this long equipment will be processed by both T-Plant and WRAP Module 2B. After T-Plant's closure in 2017, WRAP Module 2B will continue to treat this waste for the remaining years of solid waste operations.

- It is assumed that all DST/SST waste will be sent to CWC storage prior to treatment. The waste will be batched to the treatment plant from storage.

- It is assumed that the long components will be arriving in an envelope of plastic, the "flexible receiver." This flexible receiver constitutes a pretreatment volume increase of 1.2:1. These flexible receivers will be processed within T-Plant to LLMW RCRA rules, using a shred-grout process that results in a $2: 1$ volume increase.

- It is assumed that treatment will be focused on addressing the waste under the EPA debris rule and that a great majority of the waste can be decontaminated and made releasable. Pending data from operations, assume that $80 \%$ of the waste will be cleaned to CH_LLW_III levels and $20 \%$ to $\mathrm{CH}_{-}$TRU.

- The LLW III resulting from treatment will be sent directly to burial.

- The TRU waste will be cut up, characterized, and packaged for storage and eventual treatment in WRAP Module $2 \mathrm{~B}$.

- Final packaging in WRAP Module 2B of the TRU is assumed to be to the $\mathrm{CH}$ TRU waste acceptance criteria. Pending this criteria and data on the contents of the containers, it is assumed that no volume increase results from this criteria as it applies to drums of waste.

- Scenario 7.1 does not include any potential impact of having the proposed MPSC facility operate on solid waste. 


\subsection{REFERENCES}

Anderson, B. C., et al. 1990. Contact-Handled Transuranic Waste Characterization Based on Existing Record. WHC-EP-0225, Westinghouse Hanford Company, Richland, Washington.

Bafus, R. R. 1988. Functional Design Criteria: Radioactive Mixed Waste Storage Facility Project W-016. SD-W016-001, Rev. 1, Westinghouse Hanford Company, Richland, Washington.

Carlson, A. B., et al. 1993. Solid Waste Program Technical Baseline Description. WHC-SD-WM-060, Rev. 0, Westinghouse Hanford Company, Richland, Washington.

Duncan, D. R. 1989. Hanford Central Waste Complex Description. WHC-IP-0592, Westinghouse Hanford Company, Richland, Washington.

Gillins, R., et al. 1991. Assessment of High Temperature Thermal Treatment Alternatives for Inclusion Into the Scope of the Hanford Waste Receiving and Processing (WRAP) Facility. SAIC-91/1278, WHC-SD-ES-198, Westinghouse Hanford Company, Richland, Washington.

Hoover, D. A. 1991. Waste Receiving and Processing (WRAP) Facility Module 1, Project W-026. SD-W026-DC-001, Rev. 1, Westinghouse Hanford Company, Richland, Washington.

Piace, B. G. 1993. W242 Thermal Treatment Facility Technical Basis Document. WHC-SD-W242-ES002. Westinghouse Hanford Company, Richland, Washington.

Plowman, D. E. 1991. Functional Design Criteria: Enhanced Radioactive and Mixed Waste Storage Phase V Project W-112. WHC-SD-WRAP Module 112-FDC-001, Westinghouse Hanford Company, Richland, Washington.

U.S. Department of Energy (DOE). 1989. Draft Supplement Environmental Impact Statement for the Waste Isolation Pilot Plant. DOE/EIS-0026-DS, Vols. I and II, U.S. Department of Energy, Washington, D.C.

U.S. Department of Energy (DOE), Office of Environmental Restoration and Waste Management. 1991. Hanford Site Solid Waste Acceptance Criteria.

WHC-EP-0063-3, Westinghouse Hanford Company, Richland, Washington.

Valero, 0. J., et al. 1993. 1993 Solid Waste Reference Forecast Summary.

WHC-EP-0567-1, Westinghouse Hanford Company, Richland, Washington.

Venetz, T. J. 1993. Waste Receiving and Processing (WRAP) Module 2B Strategy Assessment. WHC-SD-W255-TI-001, Rev 1, Westinghouse Hanford Company, Richland, Washington.

Westcott, J. 1991. Functional Design Criteria: Waste Receiving and Processing Facility Module 2A. WHC-SD-WRAP Module 100-FDC-DRAFT, Westinghouse Hanford Company, Richland, Washington. 


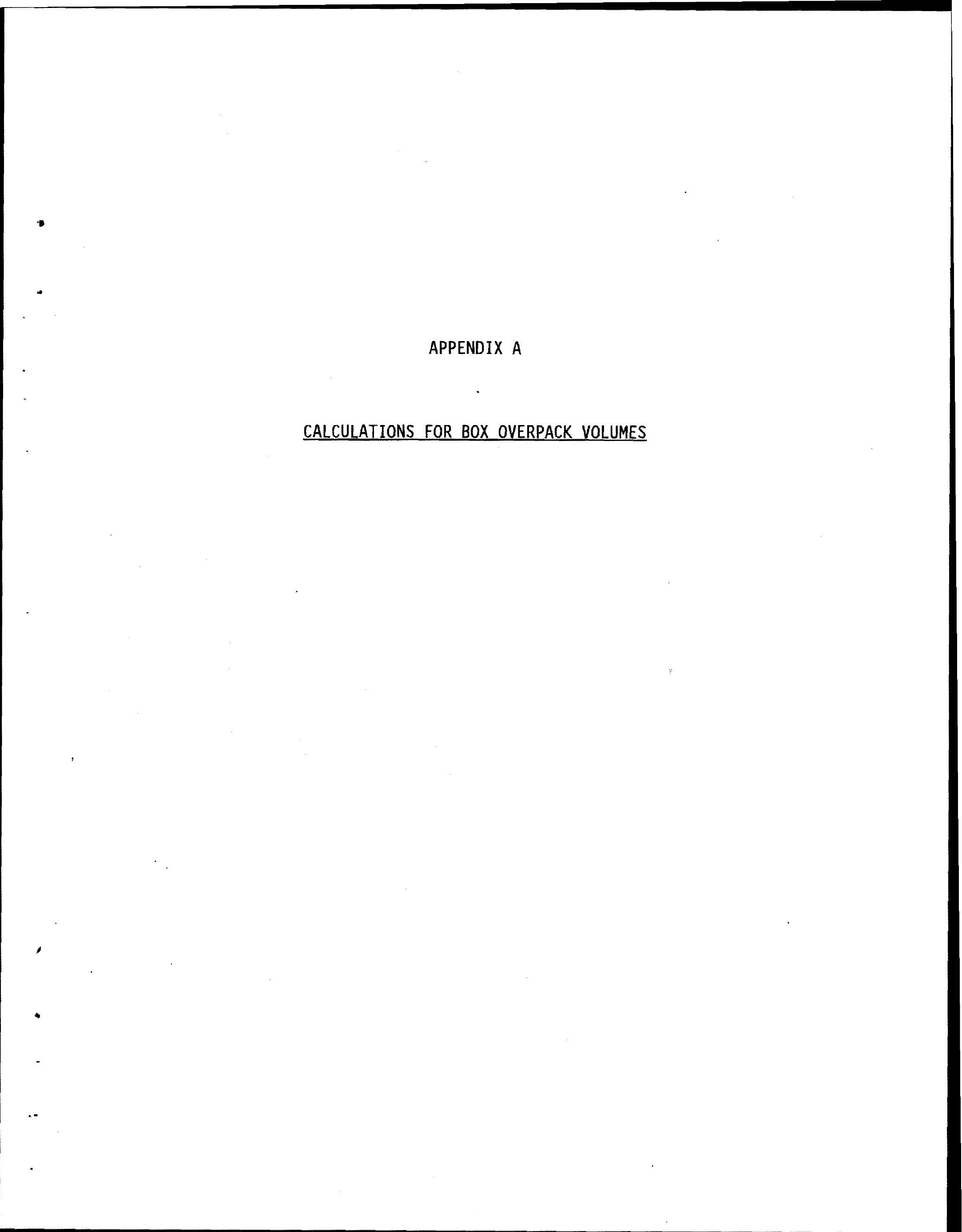




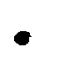


APPENDIX A

\section{CALCULATIONS FOR BOX OVERPACK VOLUMES}

The three overpack volume changes were found using a clearance of $1 \mathrm{ft}$ for the top and sides to allow for any needed space during the packaging of the box, such as a swing in the crane. A 6-in. clearance was used for the bottom for any platform on which a box may have to be placed. Using overpack wall thickness of BM-14/S, BM-36/S, and BM-68/S overpack box designs, the factors were found to be $3.3,2.0$, and 2.3 , respectively. These factors assumed maximum allowable box size to the overpack, as current plans call for the custom fitting of each overpack to the box. Unfortunately, these numbers can only be used with the particular box that was used for the calculation. There was no factor found to determine accurately a volume increase for all overpacks of any one design; this is because there would also be an increase in clearance space by that same factor. These factors cannot be used by other boxes of the same volume that differ in dimensions. For the purpose of modeling, a factor of 3 is used because most of the box sizes will fall within a range for which the factor of 3 will suffice. Only for extremely small and extremely large boxes will this factor not be appropriate, but the use of both box sizes should omit any misjudgments.

Figures A.1, A.2, and A.3 depict the space difference between the overpack volume if its box were multiplied by its respective factor and the volume if the clearance were added to the box dimensions. Figure A.4 shows the overpack-to-box ratio of the three overpacks for various cube volumes; Figure A.5 is similar but uses actual box volumes. 


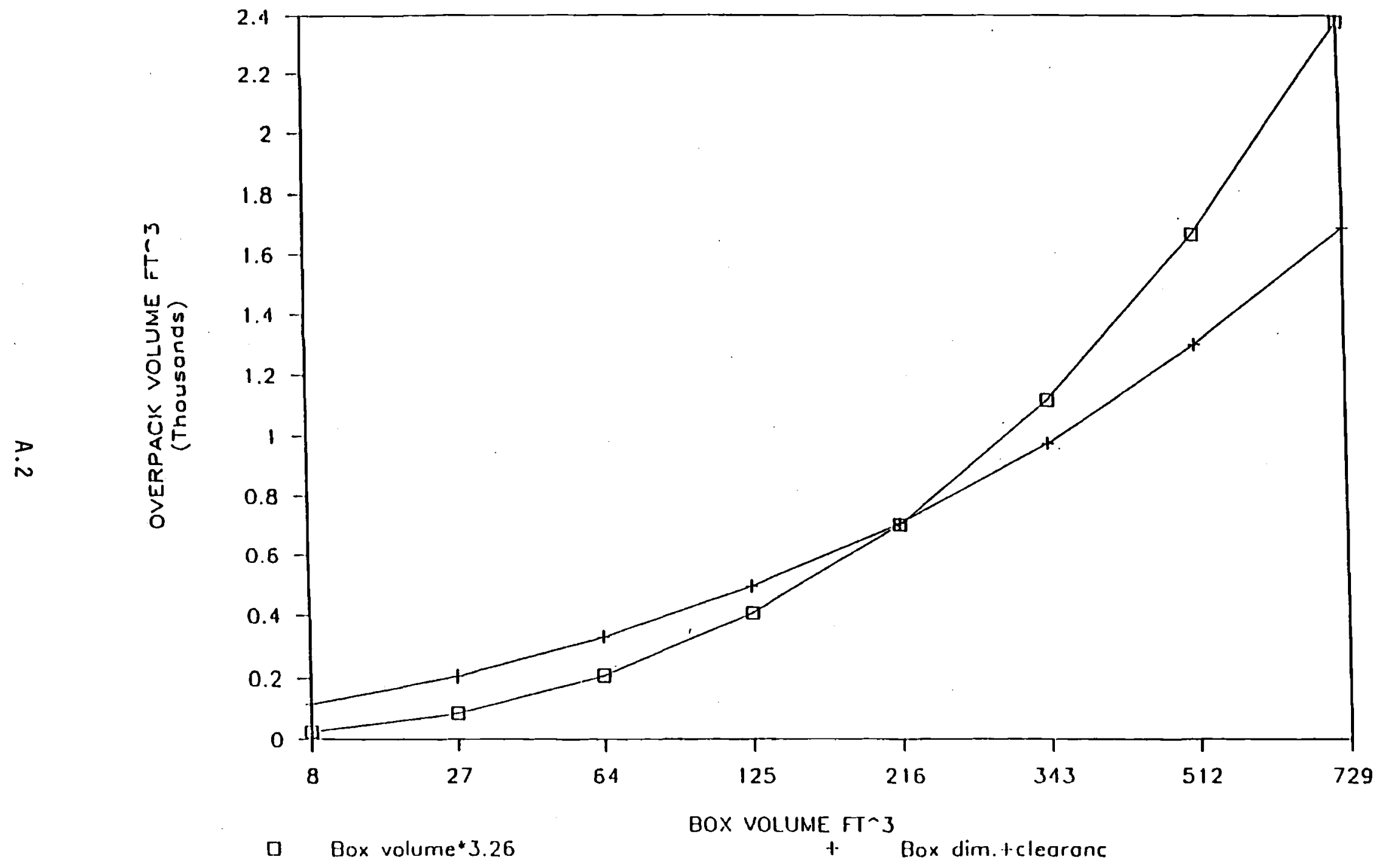

FIGURE A.1. Overpack BM-14/S 


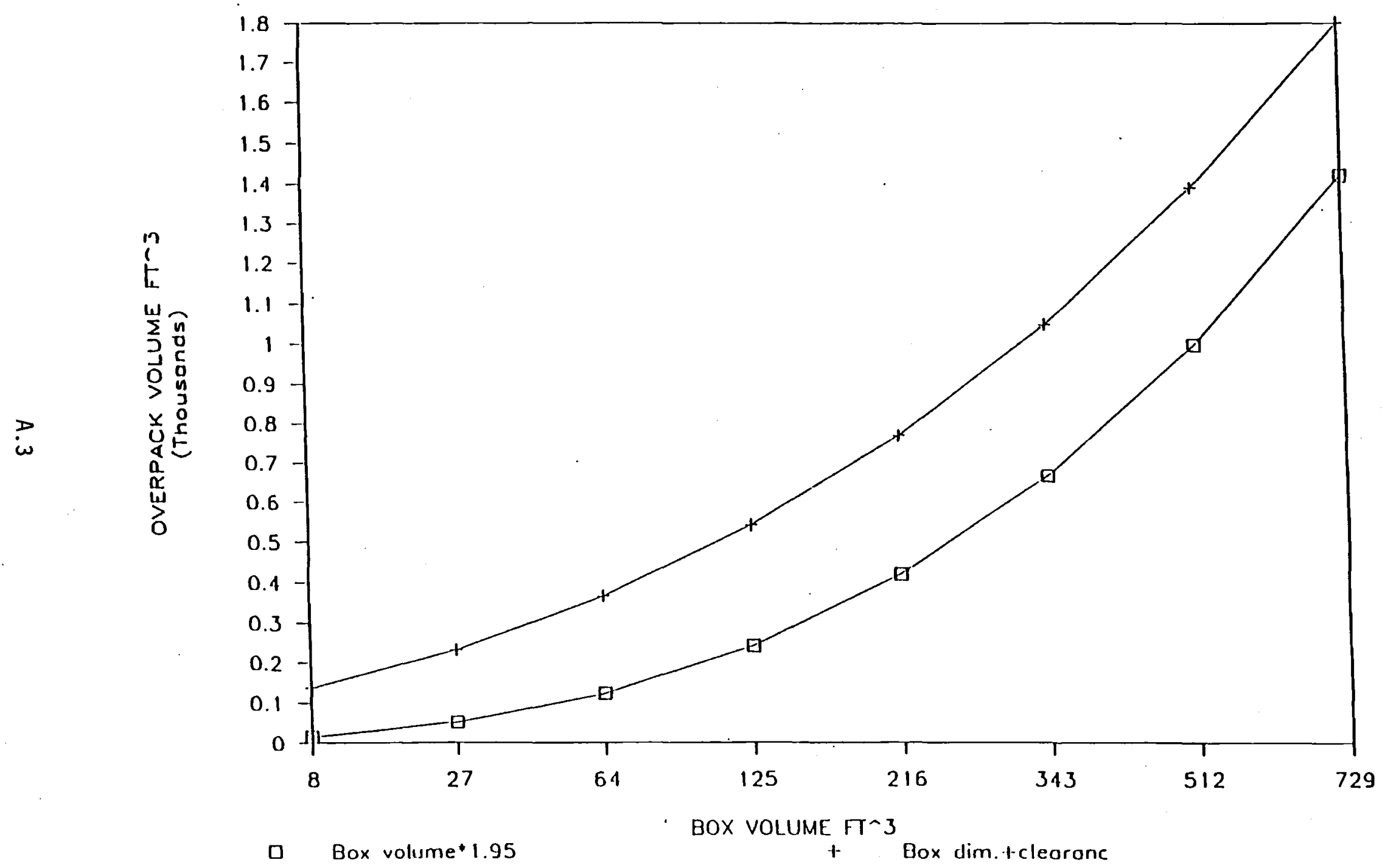

FIGURE A.2. Overpack BM-36/S 


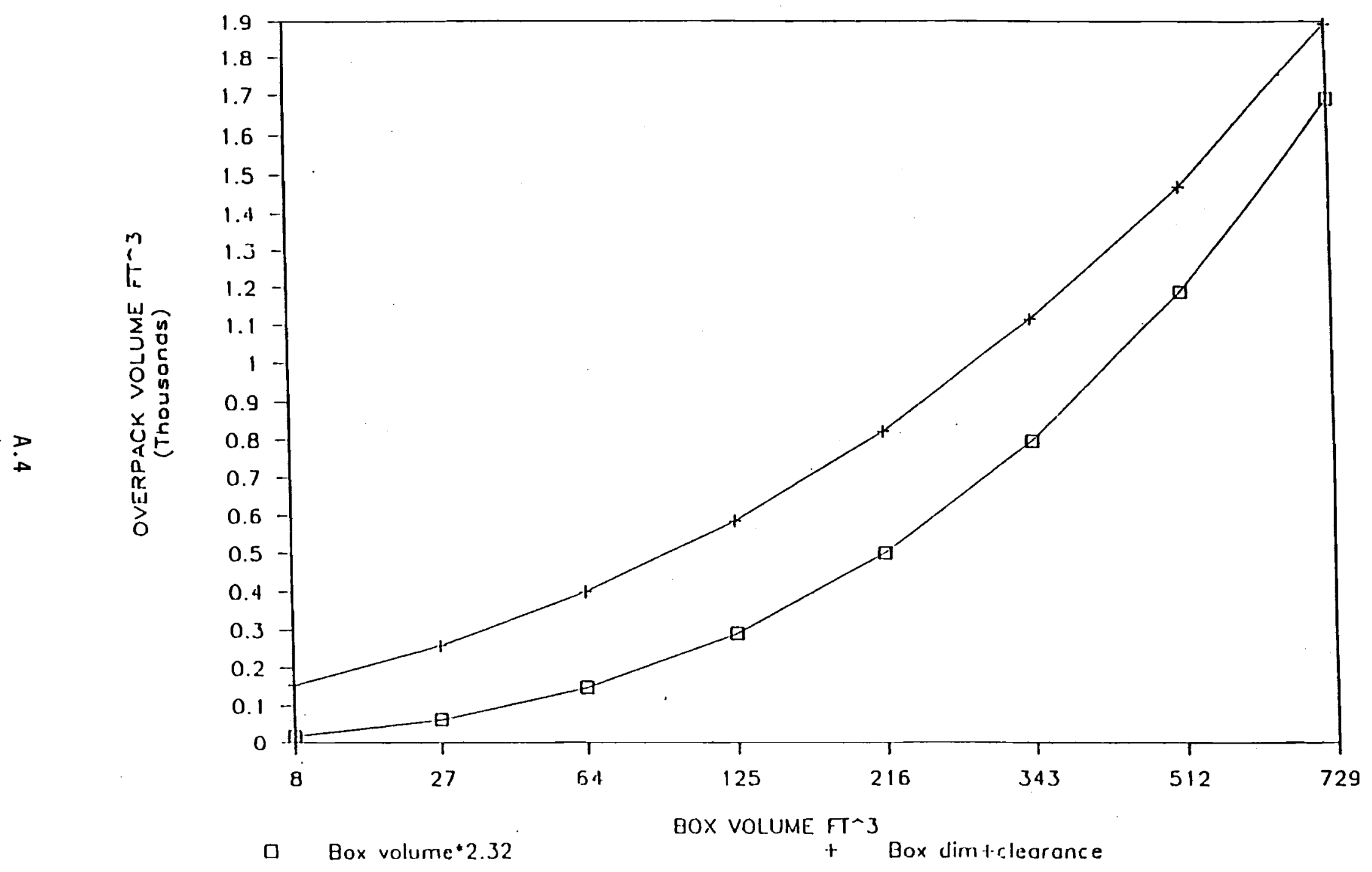

FIGURE A.3. Overpack BM-68/S 


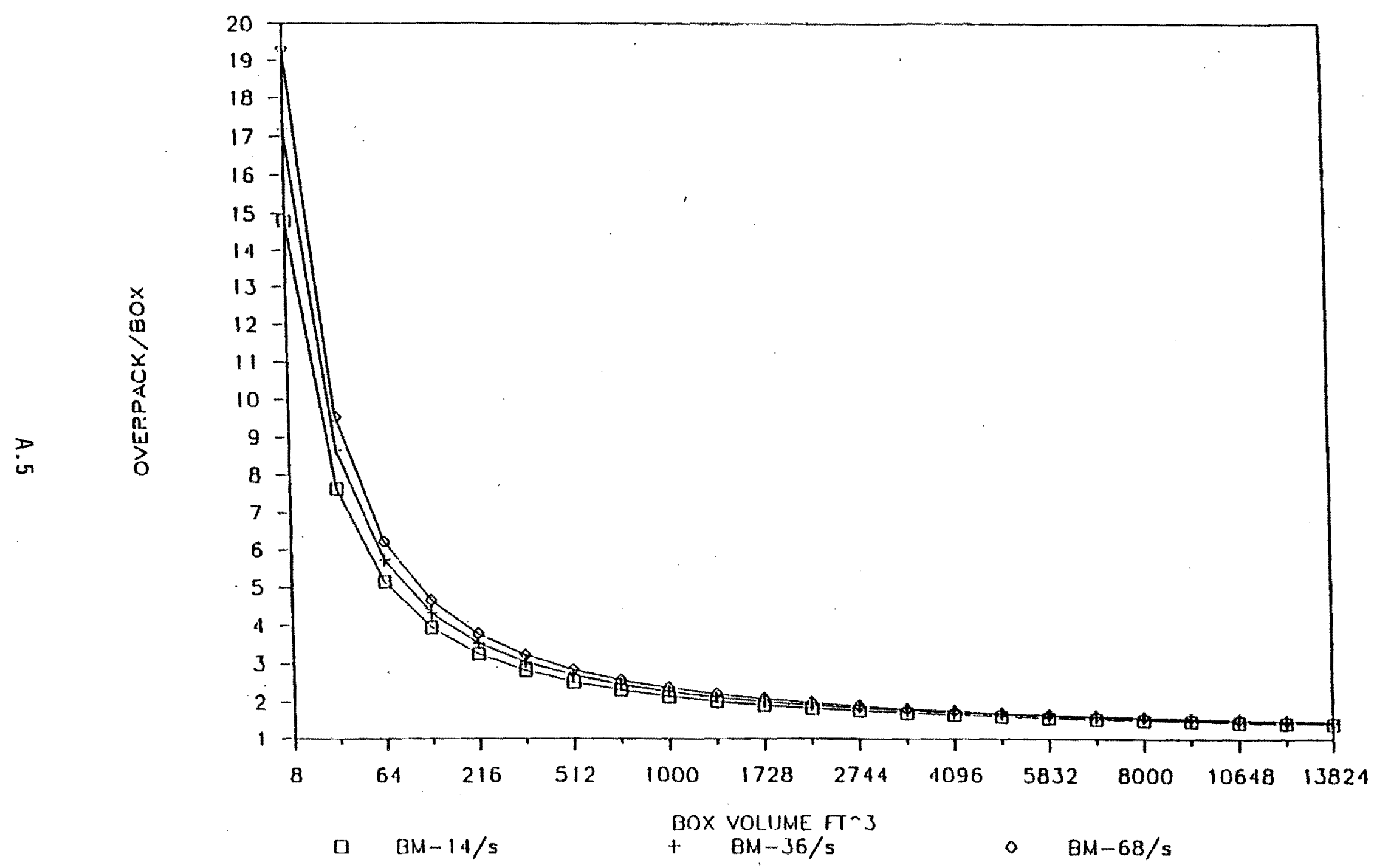

FIGURE A.4. Overpack/Box Versus Cube Box (Versus Box Volume) 


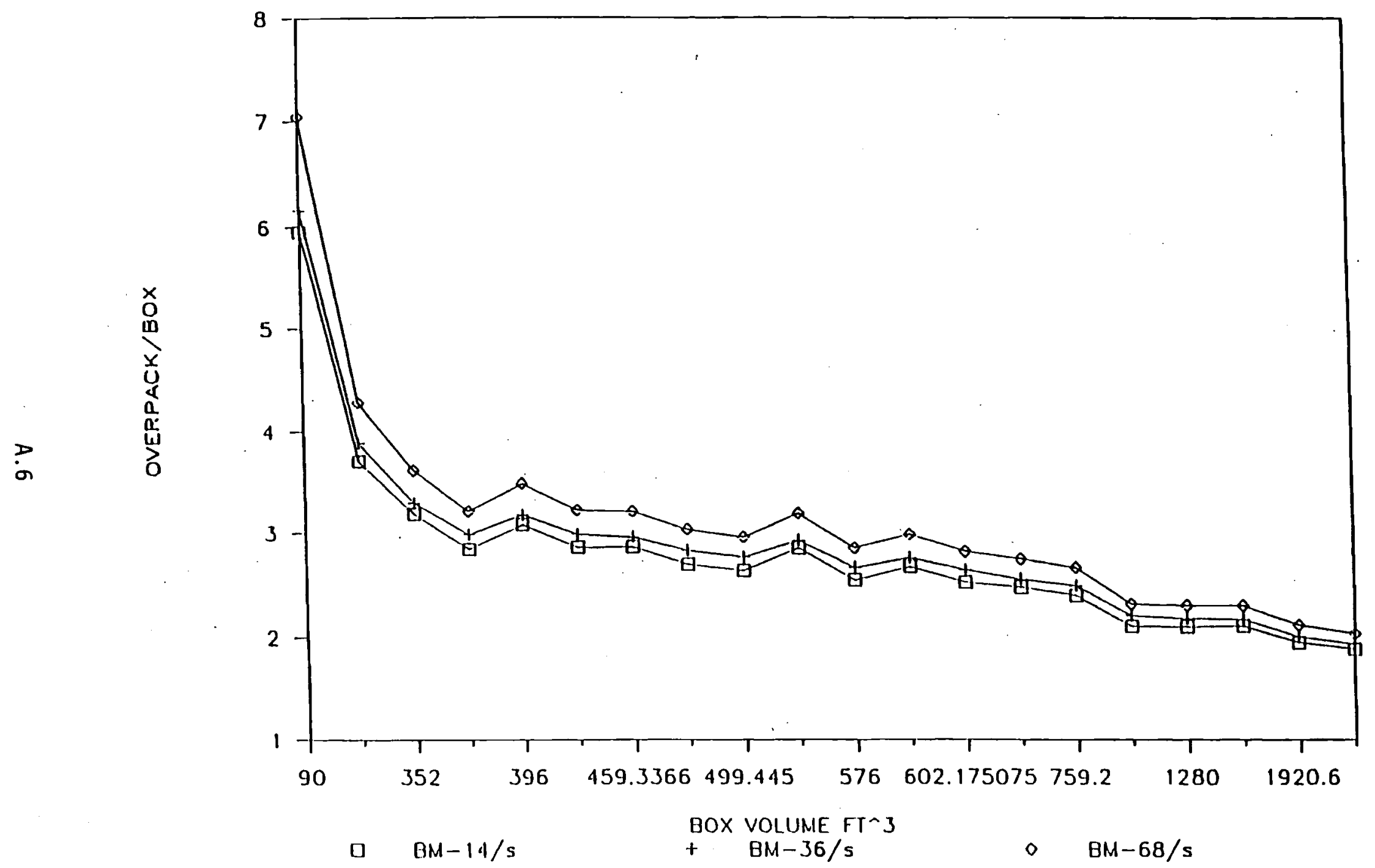

FIGURE A.5. Overpack/Box Versus Box 


\section{APPENDIX B}

CALCULATIONS FOR OPEN-SORT-PACKAGING PROCESSING IN WRAP MODULE 1 
APPENDIX B

\section{CALCULATIONS FOR OPEN-SORT-PACKAGING PROCESSING IN WRAP MODULE 1}

Data on the throughput values for the material contained herein were obtained on 8/19/93 from John Weidert, who is in charge of the WRAP Module 1 SDRD, and used the draft version of Revision 3 to the SDRD for his values. Rev. 3 is the version that addresses removal of the supercompactor from the TRU process line.

RETRIEVED SUSPECT TRU DRUMS THAT ASSAY AS LLW/LLMW FOR OPEN-SORT-PACKAGING PROCESSING IN WRAP MODULE 1

1. Based on the SDRD, assume that $50 \%$ of the retrieved suspect TRU drums are LLW/LLMW and that $50 \%$ are TRU.

The SDRD does not currently recognize that some of the LLW will be LLMW. Pending data on actual conditions, assume that $20 \%$ of the LLW/LLMW drums contain LLMW. (Reference memo, Kelley to Duncan, 3/1/93, file 87330-93-RSK-015).

The basic feedstream rate of retrieved drums to WRAP Module 1 is $2625 / \mathrm{yr}$. The LLW/LLMW fraction is, therefore, 1313/yr for each fraction. The LLW fraction is $0.8^{*} 1313=1050 / \mathrm{yr}$ and the LLMW fraction is $0.2 * 1313=263 / \mathrm{yr}$.

Assume that the LLW and LLMW fractions are campaigned through WRAP Module 1 so as to eliminate any problems with co-mingling of LLW/ LLMW and that a process glovebox cleanup occurs between each campaign.

2. The planning for addressing the drums containing retrieved waste is to supercompact them and place them in overpacks. It is expected that six incoming drum shells will be placed in one outgoing overpack. This will apply to the LLW drums, not the LLMW drums. Pending any data, assume that the existing crushed LLW drums remain LLW and are classified as LLW_I.

For the LLMW drums, assume they are simply refilled and placed in an outgoing overpack.

3. Per current WRAP Module 1 planning, LLW will be supercompacted, $3: 1$ volume reduction, but LLMW will not be supercompacted (since it will have to be treated in WRAP Module $2 A$ and supercompaction 
is not an appropriate treatment). The SDRD does not reflect these LLMW plans, but it is well understood that LLMW will not be supercompacted.

4. WRAP Module 1 SDRD planning assumes that $8 \%$ of the incoming LLW/ LLMW will be routed to the WRAP Module 1 RMW section of the process line. The volume increase assumed resulting from the RMW processing is 1.5:1 (not including the drums themselves).

5. For the LLW fraction of the 1313 total, the incoming quantity is 1050: $1050 * 0.08=84$ drum content volumes to RMW with 126 drums exiting ( $1.5: 1$ increase); $1050 * 0.92=1003$ drums entering the normal open-sort process.

For the LLW fraction, the incoming quantity is 1003 , with the outgoing quantity being a sum of the compacted drums and the compacted waste: $1050 / 6=175 ; 1003 / 3=334 ; 334+175=509$ outgoing, or a net 2.06:1 volume reduction. Overall, $509+126=635$ drums going out, for 1.65:1 overall volume reduction, including the RMW.

6. For the LLMW fraction, the incoming quantity is 263 . Using the same $8 \%$ fraction going to RMW, 21 drums go to RMW, exiting as 32 drums (1.5:1 increase).

To calculate the drums going to open-sort: $0.92 * 263=242$. The LLMW, after open-sort, is placed back into the drum and the drum is placed in an overpack (1.3:1 increase). (This overpack volume is included for volume estimation purpose in storage, and is removed once the drum enters WRAP Module 2A).

\section{FOR NEWLY GENERATED LLW/LLMW DRUMS OPEN-SORT-PACKAGING PROCESSING IN WRAP}

\section{MODULE 1}

1. The open-sort throughput values for WRAP Module 1 are $210 \mathrm{drums} / \mathrm{yr}$. This volume is made up of LLW and LLMW incoming waste for CWC receipt verification. (It is assumed that any waste sent to WRAP Module 1 from processing in other facilities will not require opensort processing.)

According to the SDRD, $8 \%$ of the volumes go to RMW $(0.08 * 210=17)$ and $92 \%$ get repackaged $(092 * 210=193)$.

The current SDRD does not address the mix of LLW/LLMW or the need to campaign waste through the glovebox. The SWPM will assume that these problems can be addressed by waste treatment management plans.

2. Waste going to RMW is processed with a volume increase of $1.5: 1$ (see the SDRD). 
Waste going to open-sort-packaging is supercompacted if LLW arriving for verification (with a $3: 1$ volume reduction, drums included); if the waste is LLMW arriving for verification, no supercompaction is applied, exiting $1: 1$.

3. Since the drums are newly generated, it is assumed that these will be used in either the RMW line or the supercompactor line. No special treatment of newly generated drums per se is required.

4. By the direction of SWD management, the SWPM will assume that a11 incoming newly generated waste is acceptable, or that the SWD facilities will accept the waste for subsequent correction. There will be no problems with waste acceptance included in the SWPM model.

NEWLY GENERATED TRU DRUMS OPEN-SORT-PACKAGING PROCESSING IN WRAP MODULE 1

1. The open-sort throughput values for WRAP Module 1 are 210 drums/yr. This volume is made up of TRU drums of incoming waste for CWC receipt verification. (It is assumed that any size sent to WRAP Module 1 from processing in other facilities will not require opensort processing.)

Following the SDRD, $7 \%$ of the volumes go to RMW $(0.07 * 210=15)$ and $93 \%$ get repackaged $(0.93 * 210=195)$.

2. Waste going to RMW is processed with a volume increase of $1.5: 1$ (following the SDRD).

Waste going to open-sort-packaging is repacked with a $1.1: 1$ overal1 volume increase (again, following the SDRD).

3. By the direction of SWD management, the SWPM will assume that al1 incoming newly generated waste is acceptable, or that the SWD facilities will accept the waste for subsequent correction. There will be no problems with waste acceptance included in the SWPM model.

\section{RETRIEVED TRU DRUMS OPEN-SORT-PACKAGING PROCESSING IN WRAP MODULE 1}

1. Based on the SDRD, assume that $50 \%$ of the retrieved suspect TRU drums are LLW/LLMW and that $50 \%$ are TRU. The open-sort throughput values for WRAP Module 1 are 1313 drums/yr.

2. By the SDRD, $7 \%$ of the volumes go to RMW $(0.07 * 1313=92)$ and $93 \%$ get repackaged $(0.93 * 1313=1221)$.

Waste going to RMW is processed with a volume increase of $1.5: 1$ (following the SDRD). 
Waste going to open-sort-packaging is repacked with a $1.1: 1$ overall volume increase (following the SDRD) for the waste that is acceptable for gram loading 1 imits (does not need to be split).

3. The plans for addressing the drums containing retrieved waste are to compact them and place them in overpacks. It is expected that six incoming drum shells will be placed in one outgoing overpack. Pending any data, assume that the exiting crushed drums are classified as LLW_I (even though they are processed in the TRU glovebox).

4. The SDRD has a value of $11 \%$ of the incoming waste exit as compacted drums (with a 1.3:1 volume increase related to the overpacks) and $89 \%$ exit as certified TRU drums. Since some of the incoming drums contain gram loadings in excess of the allowed value, some drums will have to be off-loaded, some will be acceptable as is. The SDRD assumes that $14 \%$ will be off-loaded with a net volume increase of $2.79: 1$ and $86 \%$ are acceptable, but because of repacking, wi11 have a net increase of $1.1: 1$. Together, the overal1 TRU net increase is $1.34: 1$. Thus, these are $1.34 * 1313=1755$ outgoing TRU drums.

5. The SDRD assumes the drums will be compacted and become LLW I. With $6: 1$ volume reduction, this results in $1313 / 6=219(17 \%)$ outgoing LLW_I drums.

6. The total output is the sum of $1755+219=1974$, with $89 \%$ being TRU and $11 \%$ being LLW_I.

The TRU drums must have a net increase of $1.34: 1$ and the LLW have a net increase of $1.3: 1$. 


\section{APPENDIX C}

PLANNING ASSUMPTIONS FOR SWOC FACILITY OPERATIONAL DATES 


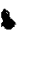


APPENDIX C

\section{PLANNING ASSUMPTIONS FOR SWOC FACILITY OPERATIONAL DATES}

WRAP Module 1. Assume WRAP Module 1 will start operations on the LLW/LLMW glovebox and NDE/NDA lines during 1/97. The TRU glovebox line will commence operations 1/98. Ramp up each $1 j j_{a} g_{(b)}$ independently. Use FDC and SDRD capacities for input feed limitations. ${ }^{(a)(b)}$

WRAP Module 2A. Assume WRAP Module 2A will start qperations 1/2000. Use FDC and SDRD capacities for input feeds limitations. ${ }^{(b)}(()$

WRAP Module 2B. Assume WRAP Module 2B will be a '02 Line Item with operations commencing with $\mathrm{CH}$ waste on $1 / 2009$ and $\mathrm{RH}$ operations on 1/2010. Ramp up each area independently. Establish capacities based on initial runs of the SWPM.

ITF. Assume the TTF will be an ' 02 Line Item with hot startup of CH_LLMW in $1 / 2013$ and RH and TRU operations in 1/2014. Ramp up each area independently. Use the TTF Technical Baseline (draft) capacities for feed limitations.

CTTF. Assume this is not a significant element in our planning at this time. Send no waste to the CTTF.

W-112 Storage. Assume W-112 will start full operations in $1 / 99$, one year later than recently $\mathrm{planned}$ because of the deferred program by DOE-HQ. ${ }^{c}$ )

Use unlimited capacity for the combined "storage" complex to determine true storage needs.

W-113 Phase I Retrieval. Phase I retrieval operations will commence 1/99 (to match $W-112$ availability) and will be completed by 12/2002 .

W-156, Alpha Caisson Retrieval. Assume alpha caisson waste will start delivery to WRAP Module 2B on $1 / 11,1$ year after RH operations start up. ${ }^{(b)}$ (c)

W-255 Phase II Retrieval. The Phase I structure and equipment will be used to commence Phase II retrieval in $1 / 2003$. The Phase II facilities will

(a) For the purposes of SWPM planning, assume a startup of 1/97 and 1/98 respectively, versus the true planned startup 3 months later.

(b) Treatment facilities will ramp up the throughput with the initial year est imated to be at 30\% of nameplate values, the second year at $70 \%$ of nameplate values, and at $100 \%$ for all remaining years.

(c) For SWPM planning, assume operations start in $1 / 2000$, versus the $p l a n n e d$ date of $9 / 99,3$ months earlier. 
supplement this and come on-1ine in 1/2008. Phase II wi11 be completed by $1 / 2019$ in order to complete retrieval and treatment to WIPP-WAC standards by $12 / 2020$.

T-Plant Upgrades for DST/SST. The upgrades will be completed to commence receipt and treatment of DST/SST components by 12/95 for operation in 1/96. T-Plant wi1l cease operations on these components when WRAP Module $2 B$ comes on-1 ine for $\mathrm{RH}$ waste in $9 / 2009$. Assume a standard throughput ramp up. Use $24,000 \mathrm{ft}^{3} / \mathrm{yr}$ capacity.

DST/SST Special Storage. The special fabric storage buildings, a total of $10,000 \mathrm{ft}^{2}$ (or $2500 \mathrm{DEs}$ ) wil1 come on-1ine in $1 / 96$ with service for 10 years (the nominal 1 ife of the fabric). Add these capacities to those now avai1able; remove them in $1 / 2006$.

IRUSAF Storage. Keep the TRUSAF capabilities in the storage system. While various capacities have been quoted, assume a nominal 2000-DE capacity.

W-213 Compactor. Assume this is not in use. Laundry waste wil1 be sent offsite.

W-272 Special Storage. Pending resolution of the scope and contents of this proposed facility, this storage capability is not included in Scenario 6.5 .

Onsite Trenches. Assume the trenches are available when needed, and have infinite capacity (so as to determine volume and timing data).

WIPP. Assume that WIPP wi1l commence operations at the earliest possible date, $1 / 2000$ (for $\mathrm{CH}$ waste only), and operate until 2020. Assume that the priority for initial shipments will be given to RFP and INEL with the CH TRU shipments from Hanford commencing 1/2002. All shipments must be made by 12/2020. Because of the emphas is on $\mathrm{CH}$ wastes at WIPP, assume RH TRU shipments are assumed to start in 2005 (or whenever WRAP Module $2 \mathrm{~B}$ can ship the waste) and be completed by $12 / 2020$.

Set the yearly capacity of WIPP to accept Hanford CH waste at 9000 drums/yr (about 1.25 shipments per WRAP Module 1 working day, assuming multiple shifts for WRAP Module 1 TRUPACT II loading operations). Assume that 70 SWBs will be sent to WIPP a year; this matches WRAP Module 1 throughput rates.

Set yearly capacity of WIPP to accept Hanford RH waste at 1575 drums/yr or three cask shipments per working day of WRAP Module 2B. Obtain data on any necessary onsite $\mathrm{RH}$ storage of treated waste.

(a) Treatment facilities will ramp up the throughput with the initial year estimated to be as $30 \%$ of nameplate values, the second year at $70 \%$ of nameplate values, and at $100 \%$ for a 11 remaining years. 
Ramp up the waste acceptance at WIPP at the same rate as treatment facilities. (a)

MPSC. Assume that the MPSC is not operational for Scenario 6.5.

(a) Treatment facilities wi11 ramp up the throughput with the initial year estimated to be $30 \%$ of nameplate values, the second year at $70 \%$ of nameplate values and at $100 \%$ for al1 remaining years. 
DISTRIBUTION

No. of

Copies

ONSITE

2 DOE/Office of Scientific and Technical Information

DOE Richland Operations Office

R. F. Guercia

15 Westinghouse Hanford Company

R. S. Kelley (15)
No. of

Copies

24 Pacific Northwest Laboratory

L. A. Armacost (10)

R. A. Fowler

G. M. Holter

H. S. Konynenbelt (2)

M. A. Oens

S. R. Shaver

D. L. Stiles

R. R. Wehrman

Publishing Coordination

Technical Report Files (5) 